A Surface Analytical Approach to the Structure of Several Starch Granules

\author{
Tamao HATTA $^{\text {() }}$, Seiko NEMOTO ${ }^{1)}$ and Keiji KAINUMA ${ }^{2)}$ \\ 1) Japan International Research Center for Agricultural Sciences (JRCAS) \\ 1-1 Ohwashi, Tsukuba, Ibaraki 305-8686, Japan \\ 2) Bio-oriented Technology Research Advancement Institution (BRAIN) \\ 3-18-19, Toranomon, Minato-ku, Tokyo 105-0001, Japan
}

\begin{abstract}
The surface of several starch granules was investigated by AFM and XPS. AFM has been used to observe the nanoscopic surface structure of various materials. XPS is used for the characterization of electron structure and chemical binding state of solid. In this study, researches of the micromorphology and the chemical state of the uppermost surface of several starch granules are reported. AFM images were collected using a SPM, SPI3800N+SPA300, by Seiko Instruments Inc.(Chiba, Japan). For high-resolution XPS, Gammadata-Scienta AB (Uppsala, Sweden), ESCA-300 equipped with a monochromatized X-ray source of AlK $\alpha(h v=1486.6 \mathrm{eV})$ was used.

AFM revealed irregularities throughout consisting of either continuous ripples or nodules on the uppermost surface of starch granules, as Fig. 1. The electronic states of starches were analyzed by XPS and a C $1 s$ spectrum that was characteristic of starch granules was obtained. As an example, the $\mathrm{C} 1 s$ spectrum of sweet potato starch is shown in Fig.2.

The lower binding energy peak was also observed in other starches, maltose, and $\beta$-Cyclodextrin, but the intensity varied among different saccharides (Hatta and Kainuma, 1997; Hatta et al., 2002). The C1s spectra showed a low binding energy tail on maltose, a shoulder on $\beta$-Cyclodextrin and a peak (or peaks) at the same position for starches. These indicate that the state of $\mathrm{C} 1 \mathrm{~s}$ at low energy site could reflect the complexity and the continuity of the molecular configurations including crystalline (Hatta et al., 1999) and double helical structure (Kainuma and French, 1972).
\end{abstract}

(a)

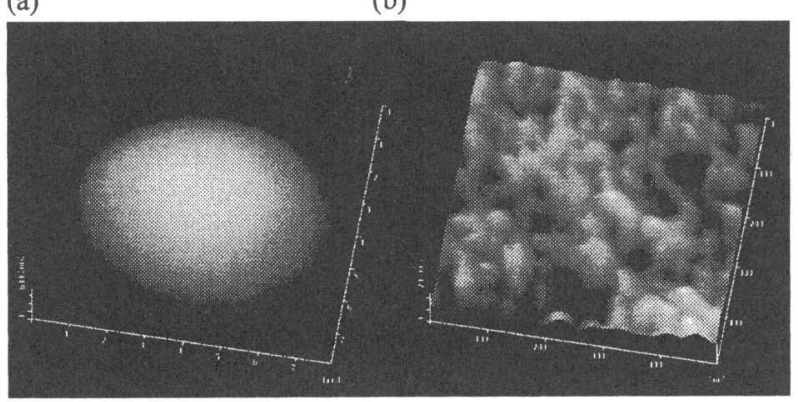

Fig. 1 AFM images of a sweet potato granule. (a): $8 \mu \mathrm{m} \square$ and (b): $500 \mathrm{~nm} \square$.

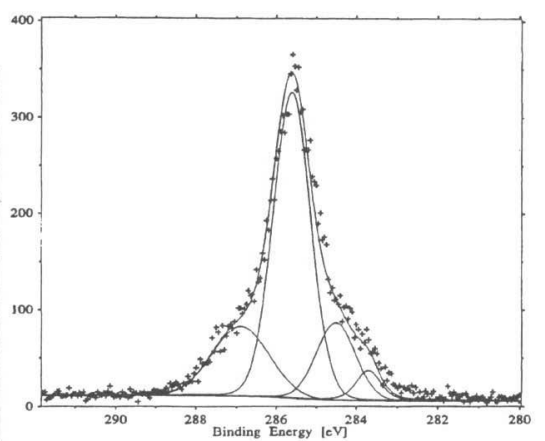

Fig. $2 \mathrm{C} 1 \mathrm{~s}$ narrow spectrum of a sweet potato granule (284.5eV for C-C binding).

Keywords: Atomic Force Microscopy (AFM), X-ray Photoelectron Spectroscopy (XPS) 


\title{
Examination of the structure of amylose and amylopectin by fluorescent labeling of the reducing terminal
}

\author{
Yasuhito Takeda and Isao Hanashiro \\ Faculty of Agriculture, Kagoshima University (Kagoshima 890-0065, Japan)
}

Fluorescent labeling of the reducing terminal of amylose, amylopectin and amylopectin side-chains with 2-aminopyridine followed by gel-permeation HPLC (FGPC) [1-3] enabled to determine directly their molar-based distribution. Also, the number-average degree of polymerization (DPn) of these molecules could be determined. F-GPC revealed more details on molecular structures than by weight-based determinations.

F-GPC showed that amylose was composed of several molecular species with different DP and differed in their molar proportion by plant source. Small amylose (DP $<1000$ ) was predominant in cereals while large amylose (DP $>1000$ ) was predominant in tubers, suggesting a difference in the biosynthesis process [1]. The DPn of amylose and number-average chain-length (CL) of amylopectin determined by F-GPC were in agreement with those determined by conventional colorimetric methods. The molarbased distribution of $C L$ was polymodal ( $A, B_{1}$ and $B_{2}+B_{3}$ chains), and characteristic by plant origin. Amylopectins from A-crystalline type starches had a higher amount of $A+B_{1}$ chains $(90-93 \%$ by mole) than $B$-type starches $(68-87 \%)$. The number of chains per amylopectin cluster, calculated from $\left(A+B_{1}\right) /\left(B_{2}+B_{3}\right)$, was 8.9-12.9 on average for A-type starches and 2.1-6.5 for B-type starches. The distribution of $\mathrm{C}$ chains was determined after isoamylolysis of labeled amylopectin, showing a broad profile from DP 10-130 with a peak at about DP 40 [2]. DPn for some cereal, root and tuber amylopectins was in range of 9900-15900. The molar-based distribution of amylopectin showed the presence of three molecular species, large (DPn 13400-25600), medium (4400-8400) and small (700-2100). Their molar proportions differed by plant origin. The large species was a major component (43-63\% by mole). The proportion of the medium (16-28\% by mole) and small (19-38\%) species was relatively large, although their weight proportion was small (1-14\%). The three species from waxy rice amylopectin showed a similar CL distribution, suggesting that all the species were basically similar in cluster structure, and differed in number of clusters per species. The number of clusters per each species suggested that the large and medium species were blocklets referred by Gallant et al [4], while the small species was immature or degraded products of the large or medium species [3].

[1] I. Hanashiro and Y. Takeda, Carbohydr, Res., 306 (1998) 421-426. [2] I. Hanashiro, M. Tagawa, S. Shibahara, K. Iwata and Y. Takeda, Carbohydr. Res., in press. [3] Y. Takeda, S. Shibahara and I. Hanashiro, submitted. [4] D.J. Gallant, B.B. Bouchet and P.M. Baldwin, Carbohydr. Polym. 32 (1997) 177-191. 


\section{STRUCTURES OF AMYLOPECTIN AND STARCH GRANULES - HOW ARE THEY SYNTHESIZED?}

Jay-lin Jane, Sang-Ho Yoo, Kit-Sum Wong, Susan A. Duvick*, and Candice Gardner*,

Center for Crops Utilization Research and Department of Food Science and Human Nutrition, Iowa State University, * USDA ARS, Plant Introduction Station, Ames, Iowa 50011, USA

Amylopectin and amylose are synthesized simultaneously mainly by soluble starch synthase and by granular bound starch synthase, respectively. Both amylopectin and amylose are synthesized radially by apposition to developing starch granules. The cross-linking reactions introduced in intact starch granules show that amylose is crosslinked onto amylopectin instead of being cross linked between amylose molecules. These results suggest that amylose molecules are interspersed among amylopectin molecules in starch granules, instead of being isolated in bundles.

Amylopectin is the major component of most starches and has much larger molecular weight ( $7 \times 10^{7}$ to $5.7 \times 10^{9}$ Daltons) than amylose and has highly branched structures. External branch chains of amylopectin are present in double helices, which form the crystalline structure of starch granules. Recent studies have shown that the molecular weight of waxy starch amylopectin is larger than that of its normal and highamylose starch counterparts. Amylopectin of starch that displays the B-type polymorphism has, in general, a smaller molecular weight and lower dispersed molecular density than does that of the A-type starch. This can be attributed to the fact that the Btype amylopectin carries fewer short, B1 chains and has larger radius of gyration than does the A-type amylopectin.

Naegeli dextrins of the A-type starch consist of more singly branched molecules than do those of the B-type starch. These results suggest that there are more ( $\alpha 1-6)$ branch linkages present within the crystalline region of branch-chain clusters of amylopectin that displays the A-type polymorphism. In contrast, branch linkages of the B-type starch are present mostly in the amorphous region and are hydrolyzed during acid hydrolysis to produce Naegeli dextrins. The large proportion of short, B1 chains with scattered branch linkages of the A-type amylopectin produce many short double helices consisting of B1 and A chains, which extend within a single cluster and are more easily rearranged into closely packed orthorhombic unit cells, reflecting the A-type diffraction pattern. The lack of B1 chains in the B-type amylopectin is related to the deficiency of certain branching enzymes, such as SBEIIb for high amylose maize starch.

Pinholes are observed on the surface of many A-type starch granules, such as those of maize and sorghum, but not on B-type starch. This feature is related to that Atype starches are more susceptible to enzyme hydrolysis than B-type starches. The nature of the pinholes is not known. A recent study using freeze-fracture techniques on maize kernels and scanning electron microscopy reveals that starch granules with holes are mostly located beneath the germ. This suggests that pinholes may occur as a result of enzyme hydrolysis of starch, which provides energy need for seed germination. 


\title{
Starch degradation in leaves
}

\author{
Alison M. Smith \\ John Innes Centre, Norwich NR4 7UH, United Kingdom.
}

Starch degradation in living plant cells is poorly understood. At least six classes of enzyme may be involved, and several different pathways can potentially operate. Although there is abundant evidence that the process must be regulated - for example throughout the diurnal cycle in leaves - little or nothing is known of the regulatory mechanisms. We are using the Arabidopsis leaf as a model in which to understand the pathway and its regulation. Our approach involves detailed analysis of carbohydrate metabolism in mutants selected for reduced ability to degrade starch, and in knock-out mutants lacking activities of putative starch-degrading enzymes. Important findings on the nature of the pathway include an essential role for disproportionating enzyme (Critchley et al. 2001: Plant J 26, 89-100), complex and interacting roles for different types of debranching enzymes, a requirement for starch phosphorylase only under certain specific conditions, and a central role for beta-amylase. These studies enable us to suggest the pathway by which degradation probably occurs. Information about the regulation of the pathway is being obtained from study of the role of the R1 protein - a starch dikinase essential for normal degradation - and from plants that accumulate and degrade the highly-branched, non-crystalline glucan phytoglycogen instead of starch. 


\title{
Understanding The Catalytic Properties And Functions Of Maize Starch Synthase
}

\author{
Hanping Guan, Jennifer Radosevich, Zhong Gao and Peter Keeling
}

ExSeed Genetics, BASF Plant Science

2901 S. Loop Drive, Suite 3800, Iowa State University Research Park

Ames, Iowa 50010, USA

We have previously reported the kinetic properties of maize starch synthase I (SSI), SSIIa, and SSIIb have distinct properties and specificities in chain elongation. However, it is not clear how starch synthesis is initiated and what the native primer for $\mathrm{SS}$ in vivo is. Therefore, in this study, we determined whether maize SS can catalyze the de novo synthesis of $\alpha$-glucan and studied how maize SS utilizes potential native primers such as malto-oligosaccharides and developing native starch granules. Using purified recombinant maize SSI, we provide evidence that maize SSI cannot catalyze the de novo synthesis of $\alpha$-glucan and the "unprimed activity" may be due to the presence of primers in ADP-glucose. However, maize SSI, SSIIa, and SSIIb, can use maltose as a primer. All malto-oligosaccharides tested can be elongated by SSI, SSIIa, and SSIIb with more than one glucose residue, indicating these enzymes are processive in nature. We also showed that purified maize SS can further elongate the chains of native starch granules isolated from developing maize waxy endosperm (18 days after pollination). The differences between SSI, SSIIa, and SSIIb in their primer preferences using MOS and native starch granule may provide some clues as to the nature of the varied functions of different SS in starch synthesis. To further understand the catalytic mechanism of SS, we have used chemical modification and mutagenesis to identify catalytic residues and substrate ADP-glucose binding site. Contrary to general hypothesis, our results indicate that the lysine residue of the conserved KTGGL domain is not directly involved in ADPglucose binding, instead, lysine 497 of maize SSIIa may be involved in ADP-glucose binding. 


\title{
Characteristics of starch branching enzyme isoforms in kidney bean
}

\author{
Hirokazu MATSUI and Hiroyuki Ito \\ Department of Applied Bioscience, Graduate School of Agriculture, Hokkaido \\ University, Sapporo 060-8589, JAPAN
}

Starch branching enzymes (SBE; EC 2.4.1.18) have a dominant role for amylopectin structure as they define chain length and frequency of branch points. Multiple SBE isoforms have been described in developing storage organs of various plants and are encoded by two gene families (A and B) based on the primary sequences.

We isolated two SBE cDNA species (designated pvsbe1 and pvsbe2) from immature seeds of kidney bean (Phaseolus vulgaris L.) and characterized the enzymatic properties of the coded recombinant enzymes (designated rPvSBE1 and rPvSBE2). The primary sequences of pvsbe 1 and pvsbe 2 displayed significant similarity to other family B and A SBEs. Northern blot analysis revealed that pvsbe 1 and pvsbe 2 were differentially expressed during seed development. Immunoblot analysis showed that these two SBEs were located in different amyloplast fractions of developing seeds; PvSBE1 was associated with the starch granule fraction, whereas PvSBE2 was present in the soluble fraction. In addition, rPvSBE1 and rPvSBE2 showed different kinetic properties and substrate preferences. These results suggest that theses two SBE isoforms have different roles in amylopectin synthesis in kidney bean seeds.

Native PvSBE2 purified from immature kidney bean seeds has a molecular mass $(82 \mathrm{kDa})$ significantly smaller than those reported for isologous SBEs from pea (SBEI), maize (BEIIb), and rice (RBE3). Additionally, in contrast to the dual location of the pea SBEI in both the soluble and starch granule fractions, PvSBE2 was found only in the soluble fraction during seed development. Based on these observations, we suspected the occurrence of a larger form of PvSBE2 and indeed identified the $100-\mathrm{kDa}$ form (designated LF-PvSBE2) containing an extended N-terminal region. LF-PvSBE2 is observed in both the soluble and starch granule fractions of developing seeds. Immunoblot and molecular analyses suggest that the two isoforms, LF-PvSBE2 and PvSBE2 are encoded by the same gene, which produces two distinct transcripts generated by alternative splicing of the first two exons. Recombinant LF-PvSBE2 (rLF-PvSBE2) showed much higher affinity but lower velocity for amylopectin than rPvSBE2. These results suggest that the extended N-terminal region in LF-PvSBE2 alters not only its subcellular location but also its kinetic properties as well. 


\title{
The dual function of $\alpha-1,4$ glucan phosphorylases in starch metabolism
}

\author{
Luc Liénard $^{1}$, Martin Steup ${ }^{2}$ and Steven Ball ${ }^{1}$ \\ UMR8576 CNRS- USC INRA-Université of Lille, 59655 Villeneuve d'Ascq - France \\ University of Potsdam, Institute of Biochemistry and Biology, D-14476 Golm
}

Starch and glycogen define the two most widespread storage polysaccharides found in living cells. Both consist of $\alpha-1,4$ linked and $\alpha-1,6$ branched glucans but differ considerably in their structure and physico-chemical properties. Because starch accumulating plastids and cyanobacteria share a common ancestor, bacterial glycogen metabolism should deserve attention as a "primitive" starch pathway. In E. coli two distinct $\alpha-1,4$ glucan phosphorylases encoded by malP and glgP define respectively the maltodextrin and glycogen phosphorylases. malP is known to be required for assimilation of maltooligosaccharides while $g l g P$ is highly suspected to be the major locus controlling glycogen catabolism. Both enzymes differ with respect to their abilities to digest glycogen and malto-oligosaccharides in vitro and by their sensitivity to inhibitors and activators. Unlike the maltodextrin phosphorylase, the $E$. coli glycogen phosphorylase is sensitive to inhibition by ADP-glucose $(\mathrm{Ki} 0.7 \mathrm{mM})$ and is slightly activated by AMP. Maltodextrin phosphorylase is also involved in glycogen metabolism. The enzyme is required to digest the maltooligosaccharides series produced by the action of the malQ $\alpha-1,4$ glucanotransferase during glycogen breakdown. These maltooligosaccharides are produced through the release of maltotetraose from the glycogen outer chains by the glgX-type of debranching enzyme. The latter is required to complete the digestion of the glycogen outer chains through glycogen phosphorylase.

In plants plastidial and extraplastidial phosphorylases have been documented. The extraplastidial enzymes favour glycogen as a substrate while the plastidial phosphorylase prefers amylopectin and malto-oligosaccharides. The plastidial enzymes are known to form either homo or heterodimers of related subunits. All plastidial subunits contain an 80 amino-acid insertion that could be involved in discrimination between high and low molecular mass substrates. It is unclear if these plastidial phosphorylases work more as malP or $g l g P$ types of enzymes. Alternatively they could assume both functions in a regulated fashion.. We now report the purification to homogeneity characterization and molecular cloning of $3 \alpha-1,4$ glucan phosphorylases from the unicellular green alga Chlamydomonas reinhardtii. Two distinct plastidial phosphorylases (phoA and phoB) are documented while a single extraplastidial phosphorylase (phoC) displays a higher affinity for glycogen as in vascular plants. The two plastidial phosphorylases are shown to function as homodimers containing two 91 $\mathrm{kDa}$ (phoA) subunits and two $110 \mathrm{kDa}$ (phoB) subunits. Both lack the typical 80 aa insertion found in the higher plant plastidial forms. PhoB is exquisitely sensitive to inhibition by ADP-glucose (Ki: $0.1 \mathrm{mM}$ ) and has low affinity for maltooligosaccharides. PhoA is moderately sensitive to ADP-glucose (Ki: $1 \mathrm{mM})$ inhibition and has a very high affinity for maltooligosaccharides. The kinetic properties of $\mathrm{PhoB}$ ckearly relates this enzyme to the $g l g P$ form of $E$. coli while PhoA can be compared to the malP type. Mutants lacking the $\mathrm{PhoB}$ form of plastidial phosphorylase were found as dramatic high amylose starch overproducers. Starch granules increased significantly in size and the size distribution of the amylopectin chains was shown to be modified. Phenotypic characterization of the $s t b 1-1$ mutants establishes $\mathrm{PhoB}$ as a major enzyme of starch catabolism in green algae. 
1-8 Pullulanase-type starch debranching enzyme function both in starch degradation and starch biosynthesis in maize Alan Myers (Iowa State Univ., U.S.A.) 


\title{
Engineering of amylopectin biosynthesis in rice endosperm
}

\author{
Yasunori Nakamura \\ Akita Prefectural University, Akita-City 010-0195, Japan
}

Amylopectin has a defined structure composed of tandem linked clusters, so to speak multiple-cluster structure, and is synthesized by multiple isoforms of three classes of enzymes; starch synthase (SS), starch branching enzymes (BE), and starch debranching enzyme (DBE). It is most likely that each enzyme plays a distinct role in determining the fine structure of amylopectin so far examined. Transgenic plants are useful materials not only to clarify the metabolic system for amylopectin biosynthesis but also to produce novel starch.

According to a model explaining how amylopectin cluster is synthesized in rice endosperm (Nakamura 2002), the balance of activities between BE and SS is very important in producing repeated clusters with species- and tissue-specific structure. BEIIb plays an indispensable role in amylopectin synthesis by producing short chains with $\mathrm{DP} \leqq 13$ of the cluster although rice endosperm has two other $\mathrm{BE}$ isoforms $\mathrm{BEI}$ and BEIIa (Nishi et al. 2001). In the transgenic plants where the BEIIb gene is introduced into an ae mutant of rice, the structure of amylopectin dramtically altered in accord with the varied level of BEIIb activity, indicating that several types of starches can be synthesized in rice endosperm by manipulating BEIIb activity.

Higher plants have two types of $\mathrm{DBE}$; isoamylase and pullulanase. Our preliminary results show that the wheat Isoamylase gene expressed in rice sugary-1 mutants that are known to be deficient in isoamylase enables them to produce starch granules instead of phytoglycogen, whereas the physicochemical properties of these starches are different from those of the wild-type starch. The result suggests strongly that isoamylase plays a key role in amylopectin biosynthesis, and that the transgene of isoamylase is useful for novel starch production.

We recently observed that SSIIa contributes to the structure of amylopectin by elongating very short chains within the cluster. The capacity of the gene would discriminate the amylopectin of japonica-type rice from that of indica-type rice in terms of lengths of the side chains of the cluster (Nakamura et al. 2002, Umemoto et al. 2002). References

1. Nakamura Y. (2002) Plant Cell Physiol. in press. 2. Nakamura Y. et al. (2002) Starch 54: 117-131. 3. Umemoto T. et al. (2002) Theor. Appl. Genet. 104: 1-8. 
I-10 Manipulating source-sink relationship via the starch regulatory enzymes ADP-glucose pyrophosphorylase for increased plant productivity and yields Thomas Okita (Washington State Univ., U.S.A.) 


\title{
Functional Interactions between Specific Starch Metabolizing Enzymes Revealed by One- and Two-dimensional Native PAGE Activity Gel Analysis of Endosperm Proteins from Maize Mutants
}

\author{
Christophe Colleoni, Alan M. Myers, and Martha G. James*
}

Functional interactions between specific starch metabolizing enzyme isoforms are believed to occur, based on historic genetic and biochemical evidence. This research investigated pleiotropic enzymatic effects in starch debranching enzyme (DBE), and branching enzyme (BE) mutants of maize, employing one- and two-dimensional native PAGE activity gels to separate proteins in extracts of developing maize endosperm. Individual bands within starch zymograms were shown to correspond to specific isoform activities by comparisons of isogenic mutant and wild type lines, by immunoblot analysis with isoform-specific antibodies, and/or by specific biochemical assay.

Zymogram analysis of BEI (sbe 1), BEIIa (sbe 2a), and BEIIb (amylose extender; ae) mutants identified multiple migratory forms for both BEI and BEIIa, and a single migratory form for BEIIb. SU1 isoamylase-type DBE migrates in three distinct forms and ZPU1 pullulanase-type DBE has a single migratory form. In each case, a genetic null mutation conditions the complete loss of all migratory forms of the respective enzyme. Analysis revealed that the ae mutation also results in loss of a particular BEI isoform and a mobility shift of one isoamylase-type DBE isoform. Allele-specific effects of isoamylase-type DBE (sugaryl; sul) mutations were observed, most notably the loss of BEIIa activity in sulstarchy (sul-st) endosperm. A null pullulanase-type DBE mutation, zpul-204, also conditions a loss of BEIIa activity. In both sul-st and zpul-204, BEIIa protein is of normal abundance and size, indicating that the pleiotropic effect is post-translational and directly impacts enzyme function. Both DBE mutants also have effects on amylases. The zpul-204 mutation results in reduction of b-amylase activity and an altered mobility of a b-amylase isoform, and particular sul mutant alleles alter the mobility of a-amylase isoforms.

Activity gels also were utilized to investigate previously uncharacterized starch metabolic activities and uncharacterized mutants that affect endosperm starch. In the first instance, an unidentified enzyme activity was found to be a glucan hydrolase of the bamylase type. Incubation of the purified enzyme with amylopectin resulted in the release of maltose as the sole reaction product; however, the enzyme was not active when glycogen, pullulan, and amylose were used as substrates. This research also examined enzymatic activities in opaque5 (o5) endosperm, a maize mutant with opaque/sugary kernels. Zymograms showed 05 endosperm is deficient in two forms of fast-migrating b-amylase activity, providing insight into the biochemical defect conditioned by the mutation.

This study demonstrates that activity gel analysis is an effective approach for identifying secondary effects of mutations at the level of enzyme function, providing information that would not be evident using RNA microarray, proteomic, or metabolomic technologies. Furthermore, the research suggests that at least some of the pleiotropic effects on enzyme activities observed in genetic mutants are most likely due to the disruption or alteration of protein complex associations. 


\title{
Naturally occurring variations in starch synthase isoforms in rice endosperm
}

\author{
Takayuki Umemoto ${ }^{1}$, Noriaki Aoki ${ }^{1}$, and Takeshi Ebitani ${ }^{2}$ \\ 1. National Institute of Crop Science, Tsukuba, Ibaraki, Japan \\ 2. Toyama Agricultural Research Center, Toyama, Toyama, Japan
}

Rice (Oryza sativa L.) consists of subspecies japonica and indica. Besides the morphological and physiological differences in rice plants between them, they also differ in rice grain quality and processing properties. It is possible that the naturally occurring variations in starch metabolizing enzymes through the alteration of starch properties are causes of the differences in the grain qualities between the two subspecies since rice endosperm deposits much of starch.

When the zymogram patterns of starch metabolizing enzymes were compared between a japonica cv. Nipponbare and an indica cv. Kasalath, or among the lines developed from a cross between Nipponbare and Kasalath, some of the isoforms showed polymorphisms. Those include granule bound starch synthase I (GBSSI), starch synthase I (SSI), starch synthase IIa (SSIIa), isoamylase, and pullulanase. Of those enzymes, three starch synthase isoforms: GBSSI, SSI and SSIIa are highlighted in this study. We used near isogenic lines (NILs) for each starch synthase, i.e. GBSSI-NIL, SSI-NIL, and SSIIa-NIL those have only a part of indica Kasalath genome with japonica Nipponbare genetic-background. These enable us to characterise effects of each variation in starch synthase locus on the composition, structure, gelatinisation properties of endosperm starch, and sensory evaluation of cooked rice. Compared to Nipponbare, GBSSI-NIL had more GBSSI protein and amylose in the endosperm starch. SSI-NIL and SSIIa-NIL differed from Nipponbare in the chain-length distribution of amylopectin although the trend and extent of differences were varied. Sensory tests of cooked rice suggested that both the naturally occurring variations in GBSSI and SSIIa affect the rice qualities greatly particularly in hardness of cooked rice, although the mode of the hardness was clearly different between the two NILs. We will also report that the variations in starch synthase isoforms might be a good clue in understanding the nature of starch binding of these isoforms. 


\title{
Starch synthesis, structure and functionality in wheat and barley
}

\author{
Matthew K. Morell, Regina Ahmed, Zhongyi Li, \\ Behjat Kosar-Hashemi, and Sadequr Rahman \\ CSIRO Plant Industry, GPO Box 1600, Canberra, ACT 2601
}

The process of starch biosynthesis in plants has been investigated intensively over the past several decades and basis elements of the process have been defined. Significant progress has been made by using model systems such as maize, Arabidopsis, Chlamydomonas and pea to define the genes responsible for steps in the biosynthetic pathway and their specific roles. It is generally agreed that starch biosynthesis involves at least four steps; substrate activation (catalysed by ADPglucose pyrpophosphorylase), chain elongation (starch synthases), chain branching (branching enzymes) and debranching (debranching enzymes).

There are significant and economically important differences between starch obtained from different species. Some of this variation is to be expected given that the organs from which commercial starch is obtained vary and include seeds, tubers and roots. In addition, the physiology of the tissues used to characterize starch from model systems used to explore the nature of unified priniciples in starch biosynthesis varies from systems primarily devoted to starch deposition (maize endosperm, pea seed), systems in which starch sysnthesis and degradation are essentially cyclic on a diurnal scale (Chlamydomonas, Arabidopsis leaves). In our research, we are focused not on model systems, but rather on the mechanisms of starch biosynthesis in two economically important crops, wheat and barley. While an understanding of the fundamental processes in starch biosynthesis drawn from model systems is critical to these studies, we are also interested in defining those differences in the starch biosynthetic processes that define the specific characteristics of starch from a specific source.

Our approach this task has been to isolate and compare mutants of starch biosynthetic enzymes in wheat and barley and compare their properties to examples of mutations in the orthologous genes from other species. In this paper, we will describe the properties of known and novel mutants in wheat and barley with their counterparts from existing known sources. From these studies, we will infer where there are differences in the control of starch biosynthesis between species that have important consequences for the nature and properties of starch biosynthesis in each species. 


\section{Isolation and Genetic Characterization of the amylopectin of Starch Mutants in Rice \\ Hikaru SATOH \\ Plant Genetic Resources, Faculty of Agriculture. Kyushu University}

Mutants modifying starch properties encourage not only to improve the starch quality but also to elucidate the genetic regulation mechanism of starch biosynthesis. We had treated the fertilized egg cells of japonica rice cultivars by N-Methyl-NNitrosourea and obtained various kinds of mutants that altered the structure and rheological properties of endosperm starch or modified the starch content.

Many mutants lowering amylose content were obtained in rice in addition to waxy mutants, of which amylose content varied from $0 \%$ to $12 \%$. Although some of low amylose mutants were caused by the mutation of waxy gene encoding GBSS, most of low amylose mutants were independent from waxy locus. Five different gene loci for low amylose' mutation were so far identified in rice. Genetic and molecular analyses suggested that some of them affect the splicing of japonica GBSS (Wx-b) transcripts. At least four kinds of enzymes are involved in the biosynthesis of amylopectin in the amyloplast, i.e., ADPglucose pyrophosphorylase (AGPase), soluble starch synthase (SSS), branching enzyme (BE) and debranching enzyme (DBE). Three forms of BE, BEI, BEIIa and BEIIb have been identified in endosperm of rice. Mutants participating in each of BEs were isolated by this treatment. Some of amylose-extender mutants such as EM 10 and EM 529 were lacking in BE IIb. In a mutant, EM 557, BE I enzyme was defected or extremely decreased and its amylopectin was characterized by the decrease amount of a part of short chain fractions in addition to long chains. Recently a mutant decreasing extremely BE IIa activity in developing endosperm, EM19, was isolated. Genetic analysis suggested strongly that they are mutants of genes encoding the respective enzymes. Two types of sugary mutations were identified in rice. Sugary 1 mutation decreased the activity levels of DBEs, isoamylase and pullulanase (PUL) and produced the highly branched starch with the extremely increased amount of short chains. Sugary 2 mutation was also characterized by the amylopectin with increased amount of short chains and decreased amount of long chains. Three mutant loci were identified on the floury mutations and all of mutations altered amylopectin structure. Although the flo 2 mutants exhibited extremely reduced level of BEI, they also decrease the levels of other starch-synthesizing enzymes, suggesting that the wild type Flo 2 gene co-regulates expression of the genes participating in starch synthesis in trans in a seed-specific manner. In addition to these mutants, mutants modifying the activity level of AGPase were also isolated in rice as well as in other plant species. Shr 2 mutation of rice reduced greatly the protein level of AGPase small subunit. 


\title{
Studies of starch synthesis in wheat endosperm amyloplasts reveal new mechanisms of regulation
}

\author{
Michael J Emes, Ian J Tetlow, Caroline G Bowsher, Matthew Cooke, Edward Scrase- \\ Field, Beatriz Albo and Emma Davies
}

School of Biological Sciences, 3.614 Stopford Building, University of Manchester, Manchester, M13 9PT, UK.

Recent studies of the subcellular compartmentation of starch synthesis have revealed differences between events in monocotyledenous endosperm compared with other starch storing tissues and species. ADPglucose pyrophosphorylase (AGPase) has been found to be located in both amyloplasts and cytosol of barley and maize. We have found a similar distribution in developing endosperm of wheat, although as much as $30 \%$ of total cellular AGPase is localised in amyloplasts, a far higher proportion than for other species. Intriguingly the wheat amyloplast enzyme is activated only 2-fold by phosphoglyceric acid when assayed in the direction of ADPglucose synthesis, and PGA does not reactivate the enzyme when it is inhibited by high concentrations of $\mathrm{Pi}$.

In view of the cytosolic localisation of the majority of AGPase activity, we have studied the transport of ADPglucose (ADPG) into amyloplasts. An ADPG transporter has been purified to apparent homogeneity from wheat endosperm amyloplasts and its kinetic characteristics determined. The transporter has been reconstituted into artificial lipid bilayers and shown to counter-exchange ADPG with ATP, ADP or AMP, but the protein does not transport UDPG. The import of ADPG from the cytosol into amyloplasts offers a means of regulating both the flux of carbon to the enzymes of starch synthesis, and the nature of the end product. The role of ADPG transport in controlling the partitioning of carbon between amylose and amylopectin will be discussed.

Given that entry as ADPG would by-pass any regulation of carbon flux by AGPase within the plastid, we investigated other possible mechanisms which might regulate starch synthesis within the organelle. ADPG was provided as a substrate for starch synthesis to intact amyloplasts. Rates of starch synthesis with ADPG, dependent upon the intactness of the preparation, were far higher than with exogenous hexosephosphates. Interestingly, low concentrations of ATP stimulated starch synthesis when ADPG was supplied to intact amyloplasts. Studies of the ADPG transporter showed that there was no direct effect of ATP on this protein, suggesting that the effect of ATP was inside the amyloplast. We have found that a number of amyloplast proteins can be phosphorylated by $\gamma\left[{ }^{32} \mathrm{P}\right]-\mathrm{ATP}$ and have partially purified a protein kinase from amyloplasts. The possible role of protein phosphorylation in regulating starch synthesis in amyloplasts will be considered. 


\title{
Sugar transporters involved in flowering and grain development of rice
}

\author{
Budsaraporn Ngampanya, Akira Ikeda, Junji Yamaguchi \\ Hokkaido University, Graduate School of Science, Kita-ku N10-W8, Sapporo 060-0810, \\ JAPAN
}

Sugars are an important source of energy and carbon skeletons for plant growth and development, but they also act as signaling molecules whose transduction pathways influence development and metabolic processes. Hexose kinases are involved in the initial metabolic step of glycolysis in cells growing on free sugars, but experimental evidence suggest that they may also act as a sugar sensor. We will present that OsHXK1, one of the rice hexose kinases, is an intermediate of sugar-signaling pathway to allow sugar-repression of alpha-amylase gene.

We investigated sugar uptake and transport in rice (Oryza sativa L.) seedling during grain germination and following leaf sheath growth. Endogenous sugar levels, accumulation of starch granules and gene expression of a rice sucrose transporter $(O S S U T 1)$ were examined using isolated embryos germinated with or without exogenous sugar supply. Overall results indicate that the expression of companion cellspecific sucrose transporter, OsSUT1 is regulated by the endogenous sugar status as well as light exposure.

Sugar transport is the most crucial process at the stage of seed development. We characterized one sucrose transporter,OSSUT1 and three monosaccharide transporters (OSMST1-3) in rice. Additionally OsSUT2 and OSMST5, which show developing seed specific-manner, have been examined. We will report the sugar transport mechanisms at the stage of seed development in cereals for taking account of the results from barley, wheat and rice. 


\title{
II-1
}

The families of carbohydrate active enzymes in the genomic era

\author{
Bernard Henrissat \\ Architecture et Fonction des Macromolecules Biologiques UMR 6098, CNRS and \\ Universites Aix-Marseille I and II \\ 31 Chemin Joseph Aiguier, 13402 Marseille cedex 20 France \\ Email: bernie@afmb.cnrs-mrs.fr
}

The complete genome sequences of over 80 organisms are now available and over 250 organisms are presently being sequenced. For each completely sequenced organism it is possible to estimate the repertoire of carbohydrate-active enzymes (glycoside hydrolases, glycosyltransferases, polysaccharide lyases, carbohydrate esterases and carbohydrate-binding modules) and, in turn, it is possible to compare the respective repertoires of the organisms. This presentation will show the evolution of the content in carbohydrate-active enzymes in archaea, bacteria and eukaryotes, with a particular emphasis of starch and glycogen biosynthesis and degradation. 


\title{
Structure and function relationship of pullulanase
}

\author{
Bunzo Mikami ${ }^{1}$, Hye-Jin Yoon ${ }^{2}$, Elif Sarikaya ${ }^{3}$, Hiroyuki Iwamoto ${ }^{4}$, \\ Yoshihiro Mezaki ${ }^{5}$ and Yoshio Katsuya ${ }^{6}$ \\ 'Graduate School of Agriculture, Kyoto University, Uji, Kyoto 611-0011, Japan, ${ }^{2}$ Division of Chemistry \\ \& Molecular Engineering, Seoul National University, Seoul 151-742, Korea, ${ }^{3}$ Department of \\ Biochemistry, Ankara University, Turkey, ${ }^{4}$ Faculty of Engineering, Fukuyama University, Fukuyama, \\ 792-0292, Japan, ${ }^{5}$ Hyogo Prefectural Institute of Industrial Research, Yukihira-cho, Suma-ku, Kobe 654- \\ 0037, Japan and ${ }^{6}$ SPring-8 Service Co, Ltd, 1-1-1 Kouto, Mikazuki-cho, Sayo-gun, \\ Hyogo 679-5198 Japan.
}

Pullulanase catalyzes the hydrolysis of $\alpha-1,6$ linkages in $\alpha$-polyglucans such as pullulan and starch. The enzyme is classified as a debranching enzyme together with isoamylase. Both enzymes belong to a family of $\alpha$-amylase. The different properties between pullulanase and isoamylase should be ascribed to their structural difference. The crystal structures of Klebsiella pneumoniae pullulanase in complex with glucose (G1), maltose (G2), isomaltose, maltotriose (G3) and maltotetraose (G4) have been determined by X-ray crystallography and refined at around 1.7-1.9 $\AA$ resolution by using a synchrotron radiation source at SP-ring 8 . The refined models contained 1052 amino acids residues, 800-1200 water molecules, 5 calcium ions and the bound sugars. The enzyme is composed of five domains (N1, N2, N3, A and C). The N1 and N2 domains are characteristic in pullulanase, while $\mathrm{N} 3, \mathrm{~A}$ and $\mathrm{C}$ domains have similarity with those of Pseudomonas isoamylase, except for the several regions of insertion/deletion. Even in A domain, there exist a large insertion after strands $\beta-2$ and $\beta-6$ in pullulanase. The N1 domain having the highest B-factor of the five was found to be a new type of starch binding domain with one calcium site. Isomaltose and G1 bound at subsite -2 , while two G4 bound at subsites $+2 \sim-1$ ' and -1 -4. The bound two G4 in the active cleft are almost parallel and interact each other. The subsites $+2 \sim+1$ and -1 -4 including catalytic site (Glu713 and Asp684) are conserved between pullulanase and $\alpha$-amylase. It is suggested that the conformational difference around the active cleft together with the domain organization determine the different specificities between pullulanase and isoamylase.

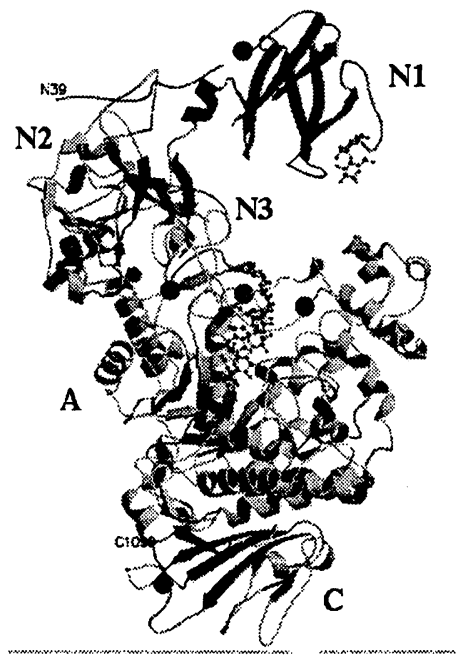




\title{
MECHANISM AND ENGINEERING OF BACTERIAL 1,3-1,4- $\beta$-GLUCANASES: FROM GLUCAN HYDROLASES TO GLYCOSYNTHASES IN ENZYMATIC OLIGOSACCHARIDE SYNTHESIS
}

\author{
Antoni Planas \\ Laboratory of Biochemistry, Institut Químic de Sarrià, University Ramon Llull \\ E-08017 Barcelona, Spain
}

Classification of glycosyl hydrolases (GHs) in enzyme families based on sequence similarities (1) has contributed to rationalize the diversity of structures and mechanistic features of glycosidase catalysis. Bacterial 1,3-1,4- $\beta$-glucanases (lichenases, EC 3.2.1.73) are the prototype of family $16 \mathrm{GH}$ which have been analyzed in our group for several years, and for which a number of mechanistic, protein engineering and structural studies have unraveled many details of their catalytic action and specificity (2). They are retaining endoglycosidases with a strict cleavage specificity for $\beta 1,4$ linkages on 3-O-substituted glucosyl units of mixed-linked 1,3-1,4- $\beta$-glucans such as cereal glucans and lichenans.

Here we summarize recent results on mechanistic aspects and on the enzyme redesign as a glycosynthase for the synthesis of oligosaccharides.

Mechanism and TS stabilization. Unlike many glycosidases, 2-deoxyglycosides are better substrates than the normal oligosaccharide substrates, indicating that the $2-\mathrm{OH}$ group of the Glc residue in subsite -1 does not participate in transition state stabilization. In addition to the catalytic residues, Glu138 as general acid/base and Glu134 as catalytic nucleophile (3), the role of other active site residues will be discused: Asp136 as the third residue in a catalytic triad that modulates the $\mathrm{pK}_{\mathrm{a}}$ of the general acid, and Tyr121 that interacts with the $2-\mathrm{OH}$ of Glc(-1) and the nucleophile having an effect on substrate binding but destabilizing the transition state.

Designing a glycosynthase. The glycosynthase concept (4), based on an hydrolytically inactive mutant glycosidase lacking the catalytic nucleophile but catalyzing transglycosylation reactions from glycosyl fluoride donors, is currently emerging as a powerful tool in enzymatic oligosaccharide synthesis. It overcomes the major drawback of kinetically-controlled transglycosylations by wild-type retaining glycosidases -hydrolysis of the newly formed glycosidic bond- so product yields are nearly quantitative. The E134A mutant 1,3-1,4- $\beta$-glucanase from $B$. licheniformis was the first reported endoglycosidase (5) which we have also used in tandem reactions with a mutated cellulase for one-pot synthesis of complex oligosaccharides (6). Results on the glycosynthase mechanism, strategies to modulate self-condensation of the donor, and acceptor specificity will be discused.

(1) Henrissat, B. (1991) Biochem. J. 280, 309-316; (2) Planas, A. (2000) Biochim. Biophys. Acta 1543, 361382 (review); (3) Viladot, J.L., de Ramón, E., Durany, O. And Planas, A. (1998) Biochemistry 37, 113321342; (4) Mackenzie, L.F., Wang, Q., Warren, R.A.J., and Withers, S.G. (1998) J. Am. Chem. Soc. 120, 55835584; (5) Malet, C. and Planas, A. (1998) FEBS Lett. 440, 208-212; (6) Faijes, M., Fairweather, J.K., Driguez, H. and Planas, A. (2001) Chem. Eur. J. 7, 4651-4655 


\title{
Enzymes for cellulose biosynthesis and degradation
}

\author{
Tuula T. Teeri \\ Royal Institute of Technology, Department of Biotechnology, AlbaNova University Centre \\ SE-10691 Stockholm, Sweden;
}

Cellulose is the most abundant organic material on Earth and an important raw material for a number of industries. The cellulosic fibres constitute the raw material for a textile as well as pulp and paper industries. If solubilised, the sugar in cellulose could be used for the production of ethanol through microbial fermentation. Biotechnological means are an attractive option for fibre degradation and modification for industrial needs.

Enzy matic degradation of cry stalline cellulose is carried out by versatile celluloly tic enzy me systems produced by many microbes. The filamentous fungus Trichoderma reesei produces two different cellobiohydrolases and several endoglucanases. The cellobiohy drolases have long, tunnel shaped active sites, which promote processive mode of action on crystalline cellulose [1-3]. The endoglucanases have more open active sites allowing random attacks leading to a rapid decrease in the degree of polymerisation. Efficient cellulase degradation is brought about by synergistic actions of the two types of enzymes.

Cellulose is synthesized and assembled by large protein complexes, "rosettes" located on the plant plasma membrane. The cataly tic subunit of the cellulose synthase, CesA, belongs to family 2 gly cosyltransferases. We have used a genomic approach to study cellulose biosynthesis in hybrid aspen and identified 5 different CesA-like clones in the EST-library from Populus tremula X tremuloides Mich. [4]. mRNA expression profiling of 3000 unique poplar cambium genes on microarrays revealed that two of the isozymes, CesAl and CesA3, were specifically up-regulated during the secondary cell wall formation and probably work as a pair [5]. Interestingly, one of the plant cellulase isoenzymes, Cel9A, was similarly up regulated during secondary cell wall synthesis. This enzyme corresponds to KORRIGAN, which has previously been shown to influence cell wall structure in Arabidopsis [6].

Aspects of the enzyme systems involved in cellulose biosynthesis and degradation will be discussed.

\section{References}

1. Teeri, T. T. 1997. Trends Biotechnol. 5, 160.

2. Divne, C. et al. 1998. J. Mol. Biol. 275, 309.

3. Zou, J-Y. et al, 1999. Structure 7, 1035-1045; 4, 1056.

4. Sterky, F. et al 1998. Proc Natl Acad Sci U S A., 95:13330

5. Hertzberg, M., Aspeborg, H. et al. 2001. Proc Natl Acad Sci U S A. 98:14732.

6. Nicol, F. et al. 1998. EMBO J. 19: 5563. 


\title{
Carbohydrate-active enzymes from alkaliphiles
}

\author{
Susumu Ito and Tohru Kobayashi* \\ Japan Marine Science and Technology Center, 2-15 Natsushima, Yokosuka 237-0061 \\ and *Tochigi Research Laboratories of Kao Corporation, 2606 Akabane, Ichikai, Haga, \\ Tochigi 321-3497 Japan
}

We have succeeded in large-scale production of alkaline cellulase, alkaline protease, and alkaline $\alpha$-amylase, using hyper-producing mutants, and the enzymes have been incorporated into heavy-duty compact detergents or bleaches. One of the most serious problems of properties of traditional alkaline protease and alkaline $\alpha$-amylase is the susceptibility to chemical oxidants, which are frequently incorporated into heavy-duty detergents and automatic dish-wash detergents (ADD). Furthermore, thermostabilization of alkaline $\alpha$-amylase is required, especially when the enzymes are used in ADD.

Alkaliphilic Bacillus sp. strain KSM-1378 produces a novel alkaline liquefying $\alpha$ amylase (KAM). The optimal $\mathrm{pH}$ and temperature of the liquefying activity were around $\mathrm{pH} 8.5$ and $55^{\circ} \mathrm{C}$. The enzyme had a molecular mass of $53 \mathrm{kDa}$ by SDS-PAGE. Soluble starch, amylopectin, and glycogen from various origins were good substrates for KAM. The structural gene for the enzyme contained a single open reading frame $1,548 \mathrm{bp}$ in length, corresponding to 516 amino acids that included a signal peptide of 31 amino acids. To use KAM in ADD, thermal and oxidative stability of the enzyme was desired. Thermostability of the enzyme could be improved by deletion of $\operatorname{Arg}^{181}$ $\mathrm{Gly}^{182}$ residues by means of site-directed mutagenesis. The engineered KAM also acquired increased stability to incubation at low and high $\mathrm{pHs}$ and to sodium dodecyl sulfate and chelating reagents, such as EDTA and EGTA. Further, the oxidative stabilization of KAM was achieved by replacing $\mathrm{Met}^{202}$ with non-oxidizable amino acid residues, such as Thr, Leu, Ile, Ser, and Ala.

Recently we found a novel, alkaline $\alpha$-amylase (AmyK38) from an alkaliphilic Bacillus isolate. AmyK38 contained neither calcium nor other divalent cations and was very stable to excess oxidants and chelating reagents. We will discuss the structural architecture of the calcium-free, oxidation stable enzyme. 


\title{
Characterization and engineering of the bacterial enzymes cyclodextrin glycosyltransferase and amylomaltase: Protein structure/function relationships, and products synthesized from starch
}

\author{
B.A. van der Veen ${ }^{1,3}$, R.J. Leemhuis ${ }^{1}$, J.C.M. Uitdehaag ${ }^{2,3}$, G.J.W. Euverink ${ }^{1}$,
} M.J.E.C. van der Maarel $^{3}$, B.W. Dijkstra ${ }^{2}$, L. Dijkhuizen ${ }^{1}$

Department of Microbiology ${ }^{1}$, Department of Biophysical Chemistry ${ }^{2}$, University of Groningen, Groningen Biomolecular Sciences and Biotechnology Institute (GBB), and Centre for Carbohydrate Bioengineering (TNO-RUG) ${ }^{3}$, P.O. Box 14, 9750 AA Haren, The Netherlands; L.Diikhuizen@biol.rug.nl; http://www.chem.rug.nl/gbb

Enzymes of the $\alpha$-amylase family, or glycosyl hydrolase family 13 , have the ability to hydrolyse and synthesize $\alpha$-glycosidic bonds in poly- or oligosaccharides in various linkage types, e.g. $\alpha(1->1), \alpha(1->4)$ and $\alpha(1->6)$. These enzymes share a common $(\beta / \alpha)_{8}$ or TIM barrel catalytic A domain, containing invariant catalytic residues, and a $\mathrm{B}$ domain, forming a substrate binding groove with this A domain, supplemented with variable additional domains. After cleavage of the glycosidic bond, a covalently linked intermediate is formed that subsequently reacts with water (hydrolysis) or with an accepting oligosaccharide (transglycosylation). The identical reaction mechanism and active site architecture of these enzymes poses challenging questions about the structural features determining their large variation in reaction specificity.

Several family 13 enzymes are interesting biocatalysts for industrial starch processing. Enzyme engineering, involving random mutagenesis and in vitro evolution techniques, is used to further improve enzyme properties, aiming for increased catalytic efficiency and improved specificity and stability. This approach greatly benefits from 3D structural information providing insights in the enzyme's interactions with substrates and products in molecular detail, allowing rational, sitedirected mutagenesis approaches. Such improved enzymes allow more efficient transformation of starch into highly added-value products of interest for food and beverages, nutrition and health applications.

Our work aims to elucidate factors determining the reaction specificity of $\alpha$ amylase family glycosyltransferases, focussing on (i) the Bacillus circulans and Thermoanaerobacterium thermosulfurigenes cyclodextrin glycosyltransferase (CGTase; EC 2.4.1.19) enzymes, and (ii) the amylomaltase (AMase; EC 2.4.1.25) enzyme of Thermus thermophilus. The 3D structures of both type of enzymes have been elucidated, allowing detailed analysis of structure/function relationships determining reaction specificity.

-Uitdehaag et al. (1999). X-ray structures along the reaction pathway of cyclodextrin glycosyltransferase elucidate catalysis in the $\alpha$-amylase family. Nature Structural Biology 6 : $432-436$

-van der Veen et al. (2000). Engineering of cyclodextrin glycosyltransferase reaction and product specificity. BBA-Protein Struct. Molec. Enzymol. 1543: 336-360

-van der Maarel et al. (2002). Properties and applications of starch-converting enzymes of the alpha-amylase family. J. Biotechnol. 94: 137-155

-Leemhuis et al. (2002). The remote substrate binding subsite -6 in cyclodextringlycosyltransferase controls the transferase activity of the enzyme via an induced-fit mechanism. J. Biol. Chem. 277: 1113-1119

J.C.M. Uitdehaag, B.A. van der Veen, L. Dijkhuizen and B.W. Dijkstra (2002). Catalytic mechanism and product specificity of cyclodextrin glycosyltransferase, a prototypical transglycosylase from the $\alpha$-amylase family. Enz. Microbiol. Technol. 30: 295-304 


\title{
Neopullulanase exhibits distinct specificity toward amylose and amylopectin
}

\author{
Hiroshi Kamasaka, Kazuhisa Sugimoto, Hiroki Takata, Takahisa Nishimura, and
} Takashi Kuriki

\author{
Biochemical Research Laboratory, Ezaki Glico Co., Ltd., 4-6-5 Utajima, \\ Nishiyodogawa-ku, Osaka 555-8502, Japan \\ E-mail: kuriki-takashi@glico.co.jp
}

We proposed a general concept for an enzyme family, the $\alpha$-amylase family including most of the amylases and related enzymes, based on the structural similarity and the common catalytic mechanisms [1-4]. Neopullulanase was the key enzyme to open the door for the formulation of the concept [5,6]. The specificity of Bacillus stearothermophilus neopullulanase toward amylose and amylopectin was analyzed. Although the neopullulanase completely hydrolyzed amylose to produce maltose as the main product, it scarcely hydrolyzed amylopectin. The molecular mass of amylopectin was decreased by only one order of magnitude, from approximately $10^{8}$ to $10^{7} \mathrm{Da}$. Furthermore, the neopullulanase selectively hydrolyzed amylose when starch was used as a substrate. This phenomenon, efficiently hydrolyzing amylose but not amylopectin, was also observed with cyclomaltodextrinase [7] and maltogenic amylase from Bacillus licheniformis. Other amylolytic enzymes, such as $\alpha$ - and $\beta$-amylases did not exhibit this distinct substrate specificity at all [8]. The unique macromolecule recognition by the neopullulanase is discussed from the perspective of the structurefunction relationships of $\alpha$-amylase family enzymes. Some properties of the amylosefree dextrin, with a molecular mass of $10^{7} \mathrm{Da}$, are also reported.

[1]H. Takata, T. Kuriki, S. Okada, Y. Takesada, M. Iizuka, N. Minamiura, and T. Imanaka, J. Biol. Chem., 267 (1992) 18447-18452.

[2]T. Kuriki and T. Imanaka, J. Biosci. Bioeng., 87 (1999) 557-565.

[3]T. Kuriki, D.C. Stewart, and J. Preiss, J. Biol. Chem., 272 (1997) 28999-29004.

[4]T. Kuriki, (1999) pp. 107-113. In: H.J. Gilbert, G.J. Davies, B. Henrissat, and B. Svensson (eds) Recent Advances in Carbohydrate Bioengineering, The Royal Society of Chemistry, Cambridge.

[5]T. Kuriki, S. Okada, and T. Imanaka, J. Bacteriol., 170 (1988) 1554-1559.

[6]T. Kuriki, H. Kaneko, M. Yanase, H. Takata, J. Shimada, S. Handa, T. Takada, H. Umeyama, and S. Okada, J. Biol. Chem., 271 (1996) 17321-17329.

[7]K. Ohdan, and T. Kuriki, (2002) pp. 99-105. In T.T. Teeri, B. Svensson, H.J. Gilbert, and T. Feizi (eds) Carbohydrate Bioengineering: Interdisciplinary Approaches, The Royal Society of Chemistry, Cambridge.

[8]H. Kamasaka, K. Sugimoto, H. Takata, T. Nishimura, T. Kuriki, Appl. Environ. Microbiol., 68 (2002) 1658-1664. 


\title{
Barley Proteome Analysis and Starch Degrading Enzymes and Proteinaceous Inhibitors
}

\author{
Birte Svensson \\ Department of Chemistry, Carlsberg Laboratory, Gamle Carlsberg Vej 10, DK-2500 \\ Copenhagen Valby, Denmark
}

Proteome analysis of barley seeds has been initiated to acquire a new tool for assessing quality with regard to malting and to monitor temporal and spatial changes in protein profiles. Extracts of developing, mature, and germinating barley seeds show highly. dynamic 2D-gel electrophoresis protein patterns. Proteins appear with different timing during the stages of grain filling. Gradually during germination, arising protease activities causing protein degradation combined with de novo synthesis of many hydrolases involved in degradation of cell walls and mobilisation of endosperm storages for the growing embryo, change the protein pattern enormously. Dissection of embryo, aleurone, and endosperm prior to extraction obviously highlights tissue differences. Among 1200 and 500 spots of silver-stained proteins separated by 2D-gel electrophoresis in the $\mathrm{pH}$ ranges 4-7 and 6-11, respectively, more than 200 have been identified using ingel digestion with trypsin and mass spectrometry (MALDI-TOF-MS, nano-ESI MS/MS) coupled with database searches. Certain proteins occur in several spots due to the presence of isozymes, post-translational modifications, or fragmentation. Identified as well as unidentified proteins constitute cultivar characteristic spot patterns. We give special attention to different forms of $\alpha$-amylase and $\beta$-amylase, the endogenous barley $\alpha$-amylase/subtilisin inhibitor (BASI), CM-proteins including inhibitors of endogenous and exogenous amylolytic enzymes and proteases, and protein $Z$ a serpin associated somehow with $\beta$-amylase. New $\beta$-amylase fragments appear and show allele segregation in the $\mathrm{pH}$ 4-7 2D-gel pattern. During germination $\alpha$-amylase isozymes appear and undergo extensive degradation, CM-proteins are decreasing, while three forms of BASI remain. Affinity fishing has led to new discoevries of target enzymes and inhibitors.

In extreme contrast to global protein profiles, investigation in structure/function relationships and protein engineering was pursued by using mutational analysis on individual proteins related to starch breakdown. Guided by three-dimensional structures several substrate binding subsites were altered in barley $\alpha$-amylase isozyme 1 (AMY1) resulting in modification of relative activities for starch, maltodextrin, and maltooligosaccharides as well as of the substrate binding modes which affected product profiles. Moreover, a newly established expression system for BASI allowed investigation of roles of specific side chains by site-directed mutagenesis followed by determination for BASI mutants and wild-type of $\mathrm{K}_{i}$ from the inhibition of activity and $\mathrm{K}_{\mathrm{d}}$ as well as $\mathrm{k}_{\text {on }}$ and $\mathrm{k}_{\text {off }}$, the rates of the AMY2 complex formation, by surface plasmon resonance (BIAcore) measurements. Both $\alpha$-amylase and subtilisin recognition by BASI were investigated. Special emphasis was given to characterize the role of the completely hydrated calcium ion at the protein interface that forms the center of a network of interactions between the proteins. Reduced affinity of BASI mutants for AMY2 was primarily due to increased $\mathrm{k}_{\mathrm{off}}$ and the AMY2/BASI complex formation was found to depend on the calcium ion concentration in accordance with the hydrogen bond contacts AMY2-water-calcium ion-water-BASI that stabilise the complex. 


\title{
二國賞 1 酥素法によるデンプンの高度変换利用技術の開発
}

\author{
福山大忘生科 小卷利章
}

この技術開発は1951年長瀬産業株式会社尼崎工場に入社以来，会社業務の一部として先 輩・同僚・仲間の技術者たちと協同で，また澱粉糖製造産業技術陣の方達のご協力による成果 である。

1, デンプンの工業的液化法の開発と難溶性デンプンについて。

澱粉の利用法の 1 つて加水分解による甘味料製造がある。酸糖化法によるグルコースの製 造法には副反忘生成物が伴、分離精製に難点があった。酵等分解については麦芽水飴に応用さ

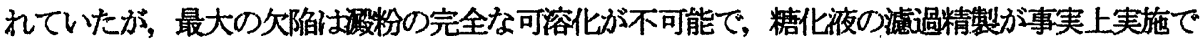
きなかった。この原因を追求し、従来の逐次昇温加熱法による液化工程の加熱過程で難溶性渐 粉が新生することを見いだし， $\alpha$ ーアミラーゼ含有デンプン乳液を瞬時に一定以上の高温度に 均一に加熱する瞬間高温加熱液化法(1956)を考案した。甘暜デンプンには $88^{\circ} \mathrm{C}$ 以、原料中 に難溶性デンプン含有量の高いコーンスターチの場合は90〜92 $2^{\circ} \mathrm{C}$ て㖡化後圧力下で再加熱 後再ひ酵素添加する2段液化法を応用し解决した (1968)。現在では超而熱性の $\alpha$ ーアミラーゼ が開発され，アミラーゼ含有デンプン乳液と加圧蒸気とを直接混合し $100 \sim 110^{\circ} \mathrm{C}$ で液化 できるようになり解決された。液化法の解决は次の酵素糖化法の開発を導いた

2, グルコアミラーゼの生産と䤂糦化法によるブドウ糖生産技術の開発。

デンプンから直接ブドウ糖を生産する酵素の存在は早くから知られていた。当初 Rhizopus niveus Yamazaki を酵素生産菌として選び，子すま教式固体培養で生産を開始したが，多量生産 及ひ糖化中の雑菌污染を防ぐため，醇素の耐熱性などの観点から，Aspergillus niger に属す る菌株を用いる深部培養法に切り替えた。この場合は転移活性を持った醭素の混在を避けなけ ればならなかった。醭桾化法の利点は稦化液中に，不都合な副生産物を含有しないため糖化 液液全量を固形化して製品とする事ができることであった (全糖方式精製プドウ糖)。低浱度の デンプン溶液では殆ど $100 \%$ 分解できるが, 高濃度の場合は生成したブドウ糖から，マルト 一ス、イソマルトースなどを逆合成するために液化のDEを低くして、糖化してもグルコース 生成率は9 2〜93\%であった。今日ではプラナーゼの併用で9 5 96\%に達している。

3, グルコースイソメラーゼの固定化と連䌇異性化反応の開発。

さらに甘味度の強い果糖への異性化の為の酳素の生産と, 固定化による連続異性化反応が実 用化(された。Streptomayces phaeochromogenesに属する生産菌は培養菌体内に酵が蓄積さ れるが、まず $60^{\circ} \mathrm{C} に$ 加熱し、自己消化に関係する酳を失活させ酵素を菌体内に安定化させ た生菌体を酵素源として回分式の異性化反応を試みた。 $65^{\circ} \mathrm{C} て ゙ 反$ 応中にp Hが著しく低下し、 中和することを繰り返すが、反応終了までに水酸化ナトリウムの消費量は対渥粉当り0１１か ら0. $15 \%$ に達し、着色も甚だしい、最全の策は酰を固定化し連続異性化反応を行なうこ とであると判断し固定化と取り組んだ。菌体内に酵素を安定化した菌体をアニオン交換樹脂の 1 種 (DAC) を用いて凝集・顆粒化・ダルタールアルデヒィト架橋・乾燥・節別の工程をえ て固定化した醇素を填型反応層に充填しカラムとし，このカラム内をを糖液を層流て流下さ せ、果楉含有率 $42 \%$ 異性化反応液を得るように流束を制御した。反忘温度と反応速度との

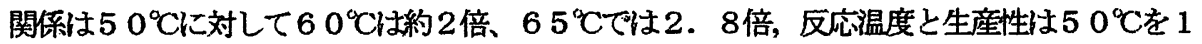
00 とすると、6 $00^{\circ} \mathrm{C}$ C $75 、 65^{\circ} \mathrm{C}$ 5 5 3を示した。これを利用し生産量を均一する力法と して使用初期には5 2〜 $54^{\circ} \mathrm{C} 、$ 後期には60〜6 $5^{\circ} \mathrm{C}$ て操作するよう勧めた。

現在酻加工法による澱粉糖の製造に用いられている溉粉の量は約 165 万トンと推定される。 


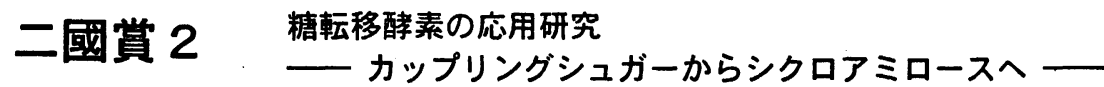 （江崎グリコ生物化学研究所）岡田 茂孝}

アミラーゼは一般的に加水分解作用の他に榶転移反応や縮合反応を示し、色々なオリゴ糖 を作りこの副反応が醉素の産業利用の上で欠点と考えられてきた。演者はこの転移作用に 着眼し、この作用を積局的に利用し応用する事を目的に研究を展開し、今日広く知られる ようになつた機能性オリゴ糖の先駆けとなるカップリングシュガーの開発に成功した。そ のほか各種配糖体の改良や、シクロアミロースと呼ばれる大型環状デキストリンの発見な どの研究を行つた。、

1) CGT-ase の開発と利用

激粉分解酥素の中で最も強力な糖転移作用を示すシクロデキストリングルカノトランス フェラーゼ (CGTase) に注目し 有望醳素生産菌を分離し、その醉素を研究したところ、㴬 粉から主として $\beta$ 一サイクロデキストリン $(\beta-C D)$ を生産する醳素であつた。䣼素の一 般的性質のほかに、どのような糖質に転移作用を示すか受容体特異性について克明な研究 を行なつた。

砂糖と浅粉の混合液に䤉素を作用させるとマルトオリゴシルスクロースが生成する。この 糖質は虫菌の原因である Streptococcus mutansによるグルカンの形成量が蔗糖に比べて 少く、虫㐘になりにくい糖質と予想された。国立予防衛生研究所雪科衛生部（現感染症研 究所口腔科学部）を中心とする大規模な研究会が数年にわたつて展開され、虫菌になりに くい糖質として カップリングシュガーの名前で発売された。本研究会の組織や研究の進 め方はその後開発された各種のオリゴ糖の研究にも同様に踏襲され機能性オリゴ糖開発の 原形となつた。

2) 配糖体の改良

糖転移醉素はオリゴ糖だけでなく各種の配糖体にも糖転移を行う。ヘスペリジン系甘味 用の溶解度の改良を目指した研究が最初に行われた。その他菊科植物の葉から取れるステ ビオール配榶体に糖転移を行うと特有のエグ味が減少する事が発見され、広く食品甘味都 として使われるようになつた。また糖転移を行つて可溶化したヘスペリジンを利用してミ カン缶詰のシラップ液の白濁を防止する事など各種の配糖体の可溶化およびその利用をお こなつた。

3) シクロアミロース（CA）の発見

各種の糖転移酵素の研究を実施中 D-酵素 (Disproportionating enzyme) がアミロース から葡萄糖 17 個以上が環状になつた CA を形成する事を発見した。更に同様な CA は洀粉 やアミロースを $\alpha$ ーアミラーゼや CGTase で分解した時反応の初期から中期に現れる事も 証明された。

C A 構造はベルリン自由大学のX一線解析グループで研究中であるが CA26（26 個の葡 萄糖が環状になつている）はメガネ状の搆造を示す事が判明している。現在量産化と利用 途の開拓が進んでいる。

\section{4) 環状デキストリンの開発}

枝作り醭はアミロースに作用し $\alpha-1,6$ 結合を含むデキストリンを作る酥素と考えら れて来たが、アミロペクチンに作用させるとアミロペクチン中の直鎖部分だけを選択的に 切り、葡萄糖 1000 個程度からなるクラスター構造のデキストリンを選択的に生成する。 出来たデキストリンは老化が痋く新しい用途が期待される。 


\section{学会賞 1 澱粉質食品素材の調理·加工適性に関する理化学的研究}

\section{（共立女子大学家政学部）高橋 節子}

調理学の教育現場で抱いた疑問や食素材との出会いから, ブラマンジェやパール状澱粉の調理 緑 豆·峑豆など物性に特徵のある澱粉を中心に利用特性の研究を行った. ハルサメに関する研究では八 ルサメ製造の原理を科学的に解明し，澱粉の老化度と者崩れなどによる澱粉の溶解との関係を明らか にした. 熱帯性澱粉の代表であるサゴ澱粉は，葛・ワラビ澱粉に似た物性をもつことを明らかにして種々 の調理，和菓子製造などに用いた結果を 1985 年第 3 回国際サゴシンポジウムで報告した. 1989 年か らは, 農林水産省が進めている国家プロジェクト「新形質米プロジェクト」に参画し, 調理·加工の面から 稲の育種の方向を判断するための指針作成の一端を担った. 1986 年カンサス州立大学に客員研究員 として滞在期間中には, Seib 教授と共同でヒドロキシプロピル化澱粉誘導体の物性に関する研究を進 めた.

これら澱粉質食品素材を中心として各種澱粉の理化学的特性や機能性の解明に魅せられながら，実 際の調理にその特性を利用して, 食物の嗜好性を高めることを目標にするという，調理の科学的解明と 調理技術を密接に結びつけた研究に心を注いできた。

\section{I 新形質米の調理·加工適性}

新しい素材開発を目的とした「新形質米の研究」では, 世界の米がもつ豊富な品質変異を日本の稲に 導入し多様な新形質素材が開発されている. また、「次世代稲作技術構築のための研究」では直播適性 が高く, 高品質多収の新品種の創出を中心とする開発が進められてきた. これらの新形質米について 炊飯や食味特性，理化学的性質などを明らかにすることにより各種の調理や加工食品への利用が期待 できることから，新形質米およびその米粉，米澱粉の調理·加工適性について研究を行った.

米の食味の違いが何に起因するかを澱粉の構造的特徴から検討する目的で, ゲル滤過法によりアミ ロース含量およびアミロペクチンの鎖長分布を求めた. またアミロペクチンの平均単位鎖長を，檜作が 改良した迅速スミス分解法により非還元末端基の測定から求めた. 米の食味之米港粉の構造との関連 から、ゲル濾過法により得られたみかけのアミロース含量が低く、アミロペクチンの長鎖長区分(Fr. II) の值が高く、平均単位鎖長の小さい米ほど柔らかく粘りのある飯であり，これらの飯は嗜好性が高いこ とから，米の食味は米澱粉の構造と深い関係のあることが明らかに認められた. 一方, 米飯の食味評価 には，食感としての硬さ·粘りなどが重要視されており，各種の米について迅速·簡便で精度の高い食味 測定法が要求されている. そこで米飯の食感を評価するために西澤が開発した新測定法について, 改 良型テンシプレッサーを用いて低·高圧縮2バイト法から硬さ·付着性の他に, こし·しなやかさを求める 方法について研究し、物性と官能評価による食味特性との関連について明らかにした.

\section{II 殸粉誘導体の調理·加工適性}

ヒドロキシプロピル化澱粉(Hydroxypropylated starch)は米国において FDA で使用が許可されてお り原料としてワキシーコーン澱粉が広く用いられている。しかし小麦澱粉に関する研究は緒についたと ころであることから, 研究室で調製した小麦・コ一ン澱粉およびその誘導体を用いて、糊化・膨潤・ゲル 化などの性質に対する化学処理の影響、脂質の影響などについて, Seib 教授と共同で研究を行った。 またこれらの誘導体を日本の食品に加えた際の効果などについて研究した。試料は米国 Midwest Grain Product 社製のヒドロキシプロピル小麦澱粉を用いて、うどんやパイフィリング・焼売の皮などに 加えた場合の物性ならびに食味特性について、米国で広く使用されている National Starch and Chemical Co. 製のヒドロキシプロピルワキシーコーン澱粉と比較した。ヒドロキシプロピル化小麦澱粉 を各種調理に用いることにより、小麦澱粉に比べて軟らかいゲルを形成し、物性の改良や調理時間の 短縮、食味の向上に寄与し、さらに低温保存性のある製品が得られるなどの効果が認められた。これら の結果は澱粉誘導体の利用が，調理食品の品質改良に顕著な効果を与えることを示したものである。 


\section{学会賞 2}

\section{セルロースの構造と醳素分解に関する研究 （信州大学 工学部）神田鹰久}

近年、セルラーゼのタンパク質構造の解析が急激に進み、立体構造が明らか になり、セルラーぜの分子レベルでの研究が進んでいる。しかしながら、個々 のセルラーゼ成分のセルロース分解に関わる役割については未解決の部分が多 い。一方、セルラーゼの基質からみた場合、セルロースは高度に発達したミク ロフィブリル(MF) の結晶構造のため水に不溶性であり、酽素反応の場は不均一 反応となり、水溶性基質に対する臲素反応と比較して挙動が異なる。ここでは 主に、白色腐朽菌の一種である Irpex lacteus のセルラーゼについて、他の起 源の異なるセルラーぜと対比し、セルロースの構造面からみた作用挙動を考え てみたい。

1. 結晶化度の異なるセルロースに対する作用 ${ }^{1 \sim 3)}$

エキソおよびエンド型酵素について、相対結晶化度、平均重合度および粒径 の明確な一連のセルロース（全てセルロース I 型）を用いて、吸着挙動および 加水分解挙動を調へ、両酵素の違いを明らかにした。また、コットンまたはバ ロニアのセルロースを用いて電顥䚁察をし、さらに DSC による非晶領域の変動 を測定し、加水分解挙動を検討した。これらの結果から両酵素は高結晶性セル ロースに対して、エキソおよびエンド機作を明確に示し、その結果両酵素に特 徵的なセルロースの結合水量の変動や MF の形態的変化が明白に観察された。こ の現象は、セルロースの結晶性の低下と共に瞹昧になる傾向を示した。これら の結果から、天然セルロースの超分子構造における変化は主に結晶領域で起こ り、個々のセルラーゼによる作用特性は高結晶性セルロースを用いた時にのみ 観察されることが明らかになった。これらのデータをもとにセルロース䄉維の 酵素分解機構を提示した。

\section{2. セルラーゼ成分間の相互作用と関連醉事 4)}

従来からの相乗作用は、主に生成する還元桾量によって論じられているが、 これはセルロース分解のある一面を見ているに過ぎない。我々は検出可能な還 元糖が生成する前に、すでにダイナミックな結晶構造の変化が生じていること をコットンを用いて観察しており、実際の相乗作用は基質の構造変化から生じ ることをバクテリアセルロースを用いて実証した。一方、これとは別に $I$. lacteus が生産するセロビオース脱水素酳素を用いて、セルロース分解における その挙動と役割についても検討を加えた。

3. その他 ${ }^{5,6)}$

今後の方向として、セルロースの酳素分解機作について、セルロースの構造 面からみたセルラーゼの作用をセルロースの分子鎖、セルロース MF およびセル ロース䋞維 (分子から集合体) に分け、酵素の立体構造を含めて進めてみたい。

1) J. Appl. Glycosci. 41, 273 (1994). 2) Cell. Commun. 2, 2 (1995). 3) J. Appl. Glycosci. 44, 87 (1997). 4) TIGG 14, 27 (2002). 5) J. Appl. Glycosci. 45, 155 (1998). 6) 瀻維学 会誌 55, 193 (1999). 
桨励賞糖質加リン酸分解酵素に関する基礎および応用研究

（独立行政法人食品総合研究所・醭素譏能研究室）

北岡 本光

グリコシド結合の消長に関与する䤃素として、主に加水分解醉素、合成酳素（糖核酸エ ステル転移酳素)、加リン酸分解醳素の 3 種類の存在が知られている。加リン酸分解酵素 は唯一実質的な可逆反応を示す酔素であり現在 13 種類報告されている。これらはその反 応の可逆性から基礎・応用両面への興味が持たれる醉素であるが、研究に着手した時点に おいてスターチホスホリラーゼ以外の加リン酸分解醭素の研究例は極めて少なかった。そ こで、酥素の作用の理解とオリゴ糖合成への応用を目指してセロビオースホスホリラーゼ を中心に数種の加リン酸分解䤃素に関する研究を行った。以下に主な成果を示す。

1. セロビオースホスホリラーゼの逆反応における新規阻害形式の発見

セロビオースホスホリラーゼの逆反応はグルコースー1 -リン酸 (G-1-P) とグルコース からセロビオースを合成する反応である。Cellvibrio gilvus 由来醭素の逆反応の速度解析を 行ったところグルコースによる強い基質阻害が見られた。この現象を速度解析の手法を用 い詳細に検討したところ、基質グルコースのもうー方の基質 G-1-P に対する拮抗阻害であ ることを示し、この阻害を拮抗基質阻害と名付けた。拮抗基質阻害は現在まで調べたすべ てのセロビオースホスホリラーゼおよびグルコニ糖加リン酸分解䣼素に見られ、普遍的な 現象であることが示唆された。

2.ミドリムシ由来ラミナリビオースホスホリラーゼに関する研究

Euglena gracilis $\mathrm{z}$ 培養細胞よりラミナリビオースホスホリラーゼを精製を試みた。うミ ナリビオースホスホリラーゼは等電点がわずかに異なるが、SDS-PAGE およひ免疫学的に 区別のできない3 種類のタンパクとして精製された。他の E. gracilis 株ではラミナリビオ 一スホスホリラーゼは 1 種類のタンパクしか存在しなかった。ラミナリビオースホスホリ ラーゼを含む $E$. gracilis 細胞抽出液を触媒として G-1-P とグルコースから種々の平均重合 度のラミナリオリゴ糖混合物を調製した。

3.スクロースのセロビオースへの高収率変換法の開発

セロビオースは新規食品素材として期待されているが、有効な生産法が知られていなか つた。そこで、スクロースをセロビオースに一段階で直接変換する方法について検討を行 つた。触媒量のリン酸の存在下スクロースに、スクロースホスホリラーゼ、キシロースイ ソメラーゼ、セロビオースホスホリラーゼの 3 醉素を同時に作用させることにより、セロ ビオースを反応収率 $90 \%$ で調製できた。高濃度のスクロースを出発原料とすることによ り、生成したセロビオースが反応系に析出する現象を利用し、反応を半連続的に行うこと により単離収率 $92 \%$ でスクロースから純度 $98 \%$ 以上セロビオース無水結晶を調製する ことに成功した。 


\section{高圧処理による食品加工の研究と米飯開発}

\section{技術開発賞 （越後製菓株式会社・総合研究所） ○山㠃 樹，杵淵美倭子}

「熱」と「圧力」とは、それぞれ独立した物質の状態変換因子でありながら、 近年まで食品の加工には圧倒的に「熱」が利用されてきた。高圧処理は、食品の 成分を構成する共有結合を開裂させず、安全性を劦かす異常物質が生じない。ま た、熱に比べて、栄養素の破壊、異臭の発生、エネルギーの消費が小さく、さら に容器中の全ての部位で、均一な処理が保証できることも未来の食品加工に適し ている。ここでは、新しい付加価値のある質的変化を得る手段として、以下に示 した種々の効果を確認したので紹介する。

（1）気泡の排除効果 : 10 100MPa 程度の比較的低い圧力で、固体内の気泡を、加圧 した液媒に溶かし込み、急速に減圧して外部に排除できる。これを利用して「湯 溶け率を $1 / 6$ に減少させた餅」や「10 分で加工できる低塩漬物」などを開発した。

(2) 液体の含浸、成分の抽出効果 : $50 \sim 300 \mathrm{MPa}$ 程度の加圧と減圧操作により、固体 内に液体の流路を形成し、固体内部への溶液の含浸、および成分の抽出効率を上 昇させた。これにより、アレルゲンを含有するタンパク質を抽出し、「低アレルゲ ン米」や吸水性に優れた「普通に炊ける玄米」などを開発した。

（3）酵素反応の制御、細胞壁や細胞膜の破壊効果 : $200 \sim 600 \mathrm{MPa}$ の処理により、生 体の細胞壁や細胞内の核膜が破壊され、細胞液の漏出が生ずる。また一部の酵素 は失活する。これを利用して酵母細胞内のトレハラーゼ（トレハロースの分解酵 素）を失活させながらトレハロースを抽出した。また産業廃棄物である余剩污泥 を加圧し、自己消化で分解性が向上できることを示した。

(4)デンプンの圧力変性効果 : 200 600MPa 程度の圧力処理により、デンプンは結 晶構造が崩れて偏光十字が消失し、熱による糊化と類似した粘性が生じ、アミラ 一ゼ消化性が高まる。各種デンプンに対し、高圧処理による水の存在状態の変化 を比較し、基礎データを得た。また、加圧処理を施した米が末処理の米より美味 しく炊飯できる原因を探り、食感の特性を明らかにした。特に高圧処理米飯では、 炊飯後の保存で老化した米飯も電子レンジで加温(調理)すると、炊きたて直後の 糊化度を越える米飯に復元することなどを見出した。さらに、この米飯を工業的 に生産する高圧製造ラインの開発と省エネルギー生産方式を確立した。

(5) 高圧処理による殺菌効果 : 400〜 700MPa の圧力処理で、多くの栄養摄取型の菌 は死滅する。しかし耐熱性芽胞菌に対しては $40 \sim 70^{\circ} \mathrm{C}$ の温度、 $\mathrm{pH}$ の調整、水分含 有率、加圧や減圧の速度、などの条件を組み合わせる必要がある。各種食品に対 し、この複合処理条件を追求し、実用化の観点から殺菌条件を示した。これにより、 自然の風味を生かした各種副材料を無菌化し、蓬餅、豆餅、海苔餅、玄米餅、多 種穀物食品などを開発した。

さらに、高圧処理では物理的、化学的、生物学的な変化が複合して生ずるので、 これを利用して「新しい米菓の製造方法」冷凍食品の低菌化」「緑色野菜の低菌化」 「液状タンパク質の固形化」食品中の有用成分の富化」など、巾広い範囲で産業界 に高圧処理が利用できることを紹介する。 


\section{Aa-1 白䞤菌キシラナーゼの好酸性機構 \\ （'東大·農生科・応生工, ${ }^{2}$ 食総研, ${ }^{3}$ 青森大 $・$ 工・生物工） \\ ○伏信 進矢 ', 宇野武生 ', 北岡 本光 ${ }^{2}$, 林清 ${ }^{2}$, 祥雲 弘文 ', 若木 高 善1,昖澤 洋3}

【目的】白錫菌 Aspergillus kawachii 由来酸性キシラナーゼ $\mathrm{C}(\mathrm{XynC}$ : 至適 $\mathrm{pH}$ 3.0)および中 性キシラナーゼ $B(X y n B:$ 至適 pH 5.0)はいずれも glycosyl hydrolase ファミリー11 に属して いる. 我々はこれまで XynC の立体構造を決定し, 酸・塩基触媒残基と水素結合している Asp37(XynB では Asn43)が好酸性に重要であることを示している. 本研究では, キシラナー ゼCの好酸性機構をさらに詳細に解析することを目的とした.

【方法】これまでの実験では水溶性キシランを基質として用いてきたか, 今回は, o-nitrophenyl $\beta$-xylobioside(ONPX2)等、各種の合成基質を作成して, 活性測定の基質に用いた.

【結果】ONPX2 に対する活性 $\left(k_{\mathrm{cat}} / K_{\mathrm{m}}\right)$ の pH 依存性プロファイルは, 水溶性キシランの結果 と若干異なっていたが, XynC D37N 变異体では至適 pH が 3.0 から 5.5 に上昇し, XynB N43D 変異体では 4.2 から 3.6 へと低下しており, この残基の至適 $\mathrm{pH}$ における重要性か確認された. また, 野生型 XynC の pH 3.0 での $K_{\mathrm{m}}$ は $19 \mathrm{mM}$ であったのに対し, pH 5.0 では $100 \mathrm{mM}$ 以上に增大することにより活性が低下していることが分かった. 一方, XynC D37N 变異体, 野生型 XynB とその D43N 変異体では, いずれの pH においても $K_{\mathrm{m}}$ は 13〜23 $\mathrm{mM}$ 程度と大 きな変化はなく, $k_{\text {cat }}$ の変化により $\mathrm{pH}$ 依存性が現れていた. これらのことから, 野生型 XynC は, $\mathrm{pH}$ の違いにより $K_{\mathrm{m}}$ が大きく異なるという特殊な性質を持っていることが分かった.

\section{Aa-2}

Bacillus halodurans C-125 株由来キシラナーゼ A のアルカリ領域で の活性発現に関与するアミノ酸残基の探索

（食総研、“三重大 生資）

○西本 完、北岡本光、粟冠和郎*、大宮邦雄*、林 清

[目的] Bucillus halodurans C-125 株由来キシラナーゼ(XynA)は pH5.8-8.8の範囲で最 大活性を示すアルカリキシラナーゼである。一方、Clostridium stercorarium F9 株由来 キシラナーゼ(XynB)は XynA とアミノ酸レベルで 73\%の相同性を有するが、その至適 $\mathrm{pH}$ は 6.0 付近である。また、 $\mathrm{pH}$ 活性曲線から計算される $\mathrm{p} K_{\mathrm{a} 1} 、 \mathrm{p} K_{\mathrm{a} 2}$ 值はそれぞれ 4.1, 9.4 (XynA)および 3.9, 7.8(XynB)であり、pK $K_{\mathrm{a} 2}$ 值に大きな違いが認められる。そこでXynA のアルカリ領域での活性発現に関与するアミノ酸残基を同定するため、XynB をもとに 変異酵素を作製し、それらの $\mathrm{pH}$ 活性相関について検討した。

[方法および結果] 一般にベル型 $\mathrm{pH}$ 活性曲線におけるアルカリ側での活性の低下はプ ロトンドナーからのプロトンの解離により説明される。そこで、XynA および XynB の モデル構造情報をもとに、プロトンドナー近傍で違いの認められる 2 つのアミノ酸残基

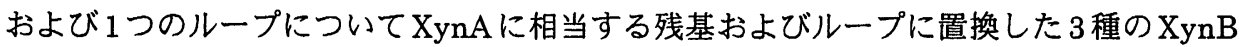

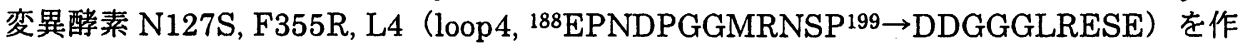
製した。精製した変異酵素の $\mathrm{p} K_{\mathrm{a} 1}$ 值はいずれも 4.0 付近、 $\mathrm{p} K_{\mathrm{a} 2}$ 值は N127S 8.2, F355R 7.4，L4 8.4 であり、 N127S および L4 変異酵素の $\mathrm{p} K_{\mathrm{a} 2}$ 值が XynB のそれに比ベアルカ リ側にシフトしていた。さらに、二重変異醳素 N127S-L4の $\mathrm{p} K_{\mathrm{a} 2}$ 值は 8.8 であった。こ れらの変異によりプロトンドナーの $\mathrm{p} K_{\mathrm{a}}$ の上昇が認められ、置換したセリン残基および loop4 が XynA においてプロトンドナーの $\mathrm{p} K_{\mathrm{a}}$ をアルカリ側に保持するために重要であ ることが示唆された。 
（食総研）○小林 厚志、Jun-Seong Park、北岡 本光、林 清

【目的】我々は今までに好熱性細菌 Thermotoga maritima 由来キシラナーゼ $\mathrm{B}(\mathrm{XynB})$ がエンド型キシラナーゼであるにも関わらず、単糖の pNP-グリコシドを 切断することを報告してきた。しかしながらその反応機構の詳細については不明で あった。本報告では pNP グリコシド分解機構の解明のために、 pNP 化糖を基質と したときの生成物の構造を同定した。

【結果と考察】XynB の基質として $\mathrm{pNP}-\beta-\mathrm{D}$-キシロシド( $\mathrm{pNP}-\mathrm{X})$ のみ反応させる

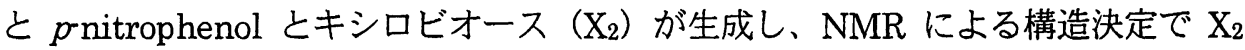
の結合様式は $\beta-1,4-\mathrm{X}_{2}$ と同定した。また、1-propanol 存在下で同様の反応を行うと、 propyl-X と $\mathrm{X}_{2}$ が生成したが、propyl- $\mathrm{X}_{2}$ は生成しなかった。このことから $\mathrm{X}_{2}$ は

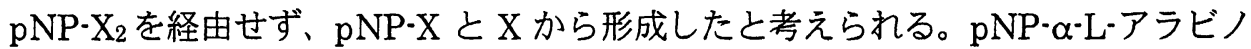
シド(Ara) と pNP- $\beta-\mathrm{D}$-フコシド(Fuc)を基質としたとき反応は二糖 $\mathrm{pNP}$ グリコシド である $\mathrm{pNP}-\mathrm{Ara}_{2}$ と $\mathrm{pNP}-\mathrm{Fuc}_{2}$ の蓄積が見られるが、最終的には $p$ nitrophenol と 単糖に分解した。中間体である二糖 pNP グリコシドの結合位置はともに 1,3 結合 であった。また、1-propanol 存在下で同様の反応を行うと、propyl-単糖が生成し た。以上のことから XynB による糖転移反応はアクセプターの水酸基の立体配座の 影響を受けることが示された。

\section{Fusion of substrate-binding domains increases substrate- Aa-4 binding capacity of a heat stable xylanase from Thermotoga maritima}

(National Food Research Institute) ${ }^{\circ}$ Farooqahmed S.Kittur, Selanere Mangala, Satoru Nirasawa, Motomitsu Kitaoka and Kiyoshi Hayashi

Family 2b XBDs from Streptomyces thermoviolaceus Xyn I and Xyn II, and Thermomonospora fusca Xyn A were fused to the C-terminus of $T$. maritima Xyn B using overlapping PCR. The chimeric genes, designated as TM XynB-STX I, TM XynB-STX II and TM XynB-TFXA were expressed as His-tag fusion proteins under the control of $T 7$ promoter of pET 28b. The hybrid proteins were purified to homogeneity by affinity and ion-exchange chromatographies. Chimeric enzymes showed $\mathrm{pH}$ and temperature-activity profiles similar to that of parental enzyme, indicating that artificial connection of binding domain do not alter the integrity of catalytic domain. Polysaccharide-binding studies showed increase in the capacity of Xyn B to bind insoluble birchwood and oat spelt xylan, and that the binding was significantly enhanced in the presence of $\mathrm{CaCl}_{2}$. Details of hydrolytic activities of these chimeric enzymes towards both soluble and insoluble substrates will be discussed in this presentation. 


\title{
Aa-5 $\begin{aligned} & \text { Addition of family VI cellulose binding domains } \\ & \text { (Clostridium stercorarium) to the catalytic domain of }\end{aligned}$ Bacillus halodurans xylanase enhanced the affinity towards insoluble xylan
}

(National Food Research Institute) OSelanere L. Mangala, Farooqahmed S. Kittur, Satoru Nirasawa, Motomitsu Kitaoka and Kiyoshi Hayashi

The two CBDs of Clostridium stercorarium Xyl A were fused to carboxy terminus of catalytic domain of the Bacillus halodurans Xyl A using overlapping PCR. The hybrid protein with a tag of six histidine residues at C-terminus was expressed in Escherichia coli. By using affinity (Ni-NTA) and Q-Sepharose column chromatography, the chimeric enzyme was purified to homogeneity. Except of optimum temperature which had shifted to $60^{\circ} \mathrm{C}$, chimera resembled the parental enzyme in other characters. It had thermal stability up to $50^{\circ} \mathrm{C}$, most active between $\mathrm{pH}$ 6-10.0 and retained $50 \%$ activity even at $\mathrm{pH} 12.0$. Binding studies showed that the addition of $\mathrm{CBDs}$ increased the catalytic activity of the chimera towards insoluble xylan. Desorption studies indicated that the chimera has an affinity for soluble saccharides in addition to insoluble polysaccharides.

Aa-6 Characterization of an Endo- $\beta$-1,4-glucanase of Thermotoga maritima Expressed in Escherichia coli (National Food Research Institute) OShakhawat Hossain Bhuiyan, Md. Majibur Rahman, Satoru Nirasawa, Motomitsu Kitaoka and Kiyoshi Hayashi

\begin{abstract}
A gene (TM1751, Swissprot Q9X273, GenBank AAD36816) of Thermotoga maritima encoding endo- $\beta$-1,4-glucanase was cloned and expressed in $E$. coli. The recombinant protein was purified by combination of Ni-NTA and Q-Sepharose FF column chromatography. SDS-PAGE analysis of Q-Sepharose active fractions showed a homogeneous protein band with expected molecular mass of $38 \mathrm{kDa}$. The optimal temperature of the enzyme was found to be $90^{\circ} \mathrm{C}$ while that of $\mathrm{pH}$ was 6.6 . The enzyme was active over a wide $\mathrm{pH}$ range (4-9.5) and stable up to $85^{\circ} \mathrm{C}$. Kinetic studies showed that the PNP- $\beta$-D-cellotetraoside and PNP- $\beta$-D-cellopentaoside had similar $K_{\mathrm{m}}$ values of 0.25 and $0.24 \mathrm{mM}$ respectively. However, maximum catalytic efficiency $\left(k_{\mathrm{cat}} / K_{\mathrm{m}}\right)$ was observed with PNP- $\beta$-D-cellopentaoside. Hydrolysis of PNP-oligosaccharides (DP up to 5) yielded a range of products with cellobiose and cellotriose being the major products. CMC hydrolysis also predominantly produced cellobiose and cellotriose. The enzyme hydrolyzed mixed linked $\beta-1,3 / 1,4$ soluble substrates such as barley glucan and lichenan more strongly than CMC.
\end{abstract}




\section{Characterization of a unique lichenase: An in vitro Aa-7 investigation of synergistic involvement of two neighboring recombinant endoglucanases from Thermotoga maritima}

(National Food Research Institute) $\bigcirc$ M. A. Sattar Khan, Satoru Nirasawa, Motomitsu Kitaoka and Kiyoshi Hayashi

A putative endoglucanase (1,3-1,4 $\beta$-glucanase) gene, lic5, corresponds to locus TM 1752 of thermophylic eubacterium Thermotoga maritima was cloned and characterized. The cloned enzyme hydrolyzed glycosidic bonds in mixed 1,3-1,4- $\beta$ linkages of lichenan and barley $\beta$-glucan efficiently in endo-fashion to produce tri-, tetra- and oligosaccharides as end products, but very low hydrolysis was observed with CMC and negligible activity was found with laminarin, curdlan, avicel, pustulan, starch, brich wood arabinoxylan and oat spelt xylan. Characters of this enzyme indicated that it is a peculiar lichenase. This Lic5 is least homologous $(\leq 18 \%)$ to lichenases of other origins and it lacks PCD block, a common feature of Bacillus lichenases of family 16 . Apart from this, Lic5 shared $29 \%$ of amino acid identity with Cel5A, encoded by neighboring upstream gene. Both Lic5 and Cel5A enzymes belong to family 5, existence of Asn-Glu-Pro motif is a characteristic of all 1,4 $\beta$ endoglucanases, of glucosyl hydrolases. A hypothesis to explain the mechanism of synergism between two endo-acting endoglucanases, an evidence is presented in the form of simultaneous and sequential hydrolysis of lichenan involving Lic5 and Cel5A enzymes. To best of our knowledge, this data suggested that 1,3-1,4 $\beta$-glucanase represents the first novel Lic5 in order thermotogales.

\section{Aa-8 Pectate Lyase from a Thermophilic Bacterium, Thermotoga maritima: Cloning, Expression and Characterization.}

\section{(National Food Research Institute) O Ahmed Abu Rus'd, Motomitsu Kitaoka and Kiyoshi Hayashi}

The gene encoding pectate lyase of the hyperthermophilic bacterium Thermotoga maritima was cloned and expressed in $E$. coli. The enzyme belongs to the polysaccharide lyase family- 1 that cleaves pectic acid by $\beta$-elemination and generates products with a 4,5 unsaturated residue at the nonreducing end. The recombinant enzyme was purified to apparent homogeneity and showed an approximate molecular mass of $43 \mathrm{kDa}$ on SDS-PAGE. The enzyme showed an optimum temperature of $80^{\circ} \mathrm{C}$, indicating its thermostability. The $\mathrm{pH}$ optimum of the enzyme was 10.0. The enzyme was dependent on calcium for its activity. Further characterization of the enzyme is in progress. 


\section{Aa-9 Characterization of M-1 lysozyme produced by} Streptomyces globisporus by analyzing cell wall hydrolyzate

(National Food Research Institute ${ }^{1}$, Mie university ${ }^{2}$ ) $\bigcirc$ Hyo Jin Seo ${ }^{1,2}$, Kunio Ohimiya ${ }^{2}$ and Kiyoshi Hayashi ${ }^{1}$

M-1 of Streptomyces globisporus possesses both $N, O-$ diacetylmuramidase and $\mathrm{N}$-acetylmuramidase activity in contrast to hen egg white lysozyme possessing only $N$-acetylmuramidase activity. The aim of this study is to characterize the difference of the two enzymes by analyzing the hydrolyzate of the cell wall. Cell walls prepared from Micrococcus luteus and Staphylococcus aureus were used as substrates. The hydrolyzate of the cell wall was analyzed by thin-layer chromatography, gel filtration column chromatography and HPLC. In case of hydrolyzate of $M$. luteus cell wall by lysozyme, main peak was identified as disaccharide (GlcNAcMurNAc) while this disaccharide peak was not detected in the hydrolyzate by $\mathrm{M}-1$. The analysis of hydrolyzate of $S$. aureus cell wall is also discussed.

\section{Aa-10 大豆由来可溶性食物纎維のアラビナナーゼ活性誘等因子について \\ （鹿児島大裳・生资化） \\ ○西雅仁、菅沼俊彦、北原兼文}

【目的】土燷より分離したバチラス属 M 6 菌の生産するアラビナナ一ゼは、アル カリ側に作用領域をもち、可溶性大豆食物瀻維で顥著にその生産性を上界するこ とを見い出している。今回は、大豆食物錶維のうち活性誘透に関与している部分 槽造を探るため、67\%アルコールで沈殿しない低分子画分と、粗醉絫により分 解され生成する禟の糖組成とを比較した。

【方法】可溶性大豆食物織維としてフ踣油製市販ソヤファイブS-DNを用いた。

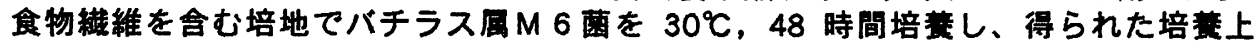
澄み液を粗臯素液とした。可溶化䌅の糖組成は加水分解後、PA10 カラムを用いる HPAEC-PAD 法で単糖分析を行った。末端糖の分析は、通元後加水分解して禟了 ルコールの種類をMA1 カラムを用いる HPAEC-PAD 法で決定した。

【結果】M 6 菌の粗酷素は、アラビナナーゼ活性を主体に、 $\beta$ ーグルカナーゼ、 キシラナーゼ、ガラクタナーゼなどの活性を合む。M 6 粗酻素を、可溶性大豆食 物戥維に作用させたところ、ガラクトースを主成分とするオリゴ絠を生成するこ とが分かった。また、その末端榶はガラクトースであった。一方、可溶性大豆食

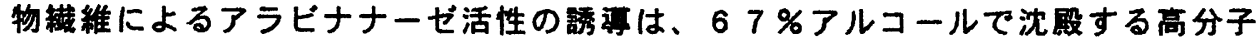
画分ではなく、上澄みの低分子画分の方が顕著に高いことが分かった。その糖組 成の主体はアラビノースであった。単糖のアラビノースでは活性誘等が起きない ので、アラビノースを主成分とするオリゴ榶が誘等活性を持つと考えられた。 
ß-Glucosylamidine をリガンドとする $\beta$-グルコシダーゼのアフィニティー Aa-11 精製 一チャ炗由来 2 種の $\beta$-グルコシダーゼの精製と性質—

(京大化研 ${ }^{1} 、$ 安徽農業大学・ 中国 ${ }^{2}$ )

○平竹 潤 1 、張 正竹 ${ }^{1,2}$ 、水谷正治 ${ }^{1}$, 井上和子 1, 宛 暁春 ${ }^{2}$ 、坂田完三 1

【目的】 $\beta$-グルコシダーゼを選択的かつ強力に阻害するテーラーメードな阻害剤とし て開発した $\beta$-glucosylamidine をリガンドとしてアフィニティー吸着体を作製し、チャ葉 から 2 種の $\beta$-グルコシダーゼをアフィニティー精製、その醉素学的性質を調べた。

【方法】Amino Toyopearl 650M を担体とし、適当なスペーサーを介して、末端にリガ ンドである $\beta$-glucosylamidine をワンポットで固定化したアフィニティー吸着体を作製し た。チャ葉から調製した粗酥素をアフィニティーカラムに供し、buffer および $1 \mathrm{M} \mathrm{NaCl}$ で洗浄後、D-glucose で溶出させることにより、2 種の $\beta$-グルコシダーゼ | および ॥ を 精製した。

【結果】同じアフィニティー吸着体を用いて、それぞれ pH 6.0 および 5.0 でクロマ トを行うことにより、2 種の $\beta$-グルコシダーゼ I, II を、それぞれ電気泳動的に単一な 62 および 84 kDa のタンパク質として精製した。pNP-Glc を基質としてそれぞれの酵素の

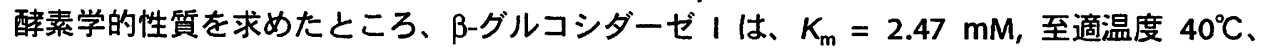

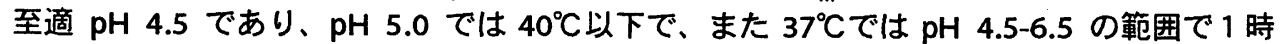

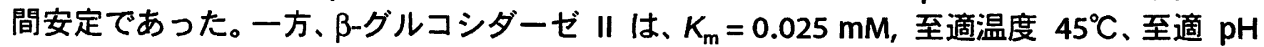

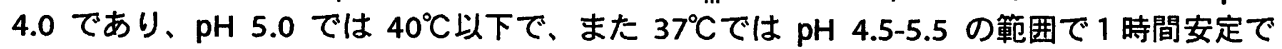
あった。

\section{Molecular anatomy of $\beta$-glucosidase; \\ Aa-12 Co-refolding of the two proteins coded by the genes split in the middle resulted in catalytically active form}

(National Food Research Institute) OBong-Jo Kim, Satoru Nirasawa, Motomitsu Kitaoka, Kiyoshi Hayashi

Family $3 \beta$-glucosidase from Agrobacterium tumefaciens is a monomeric enzyme consisted with 721 amino acid residues. Based on the amino acid alignment, the enzyme is consisted with three parts; $\mathrm{N}$-terminal domain containing catalytic nucleophile/base of D222, non-homologous region and C-terminal domain containing catalytic proton donor of E616. The four sites at $351,421,466$ and 533 were selected in the gene of the non-homologous region in order to separate the catalytic residues. When these fragmented 8 genes were expressed separately in $E$. coli, they were obtained as inclusion body. No enzyme activity was detected when these proteins were refolded separately. However, catalytically active protein was obtained when the two proteins (1- 421 protein and 422-721 protein) were refolded together. The values of $K \mathrm{~m}$ and $k$ cat for the co-refolded protein were $0.129 \mathrm{mM}$ and 6.26 $\mathrm{s}^{-1}$ while those of the native enzyme were $0.012 \mathrm{mM}$ and $95.4 \mathrm{~s}^{-1}$. 
Thermotoga maritima由来Family $4 \alpha$-グルコシダーゼに相同性の高い遺 伝子のクローニング : 新規 $\alpha$-グルクロニダーゼの発見

（食総研）○北岡本光, Cuddapah Suresh, Ahmed Abu Rus'd, 林 清

【目的】Thermotoga maritima $\alpha$-グルコシダーゼ (AglA)はpNP- $\alpha-G l c$ 分解活性を指摽にク ローニングされた䤃素であり"、他の $\alpha$-グルコシダーゼと異なり (Family 13，31）アミノ酸 配列上唯一Family 4 に分類された。後に本菌の全ゲノム配列が報告され、AglA遭伝子

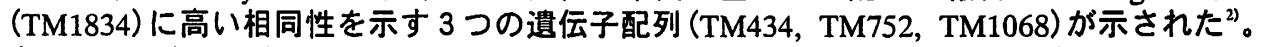
今回はこれらの遭伝子産物の酥素活性について報告する。

【方法】TM434とTM0168はアミノ酸レベルで99\%の相同性を示し、ほぼ同一のタンパク と考えられた。そこで今回はTM434, TM752遺伝子をクローニングし、大腸菌に発現させ た。得られた酵素の活性をスクリーニングするとともに、酥素化学的諸性質を調べた。

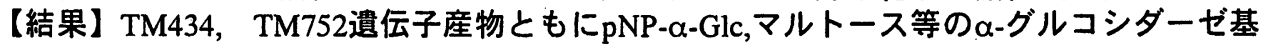
質を分解しなかった。またFamily 4 䤃素に含まれる、 $\alpha$-ガラクトシダーゼ、6-ホスホ- $\alpha-$

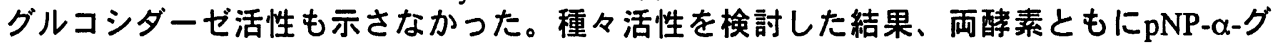
ルクロニド水解活性を有する $\alpha$-グルクロニダーゼであることが示された。しかしながら、

グルクロノキシランおよびそのフラグメントオリゴ糖は水解しなかった。両醳素ともに活 性の発現にチオール化合物および $\mathrm{Mn}^{2+}$ 要求した。また、TM752醉素はNAD+の存在下に 活性化が見られた。これらの性質はFamily 4 酵素に一般的に見られるものである。TM434

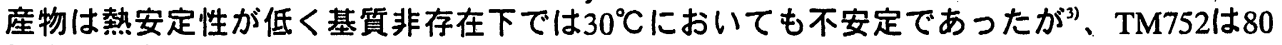
${ }^{\circ} \mathrm{C}$ まで安定であった。

1) Bibel et al., FRMS Microbiol. Lett., 158, 9 (1998); 2) Nelson et al., Nature, 399, 323 (1999)

3) Suresh et al., FEBS Lett., 517, 159 (2002).

\section{Aa-14}

アスパラガス葉由来 $6^{G}-\beta$-D-fructosyltransferase 遺伝子のクローニング

(酪農大院・食品科学、北農研・越冬ストレス*)

○上野敬司、小野寺秀一、川上顕 *、吉田みどり*、塩見德夫

【目的】我々はアスパラガスより1-kestoseから $1^{F}, 6^{G}$-di- $\beta$-D-fructofranosylsucrose (4c) の生成を触媒する6 $6^{G}-\beta$-D-fructosyltransferaseを初めて見い出し、精製し、諸性質を検討 した ${ }^{1)}$ 。本研究ではアスパラガス葉CDNAライブラリーより、6 $6^{G}-\beta$-D-fructosyltransferaseをコードするcDNAの単離、塩基配列の決定、醭母 Pichia pastoris によるコー ドタンパク質の発現を試みた。

【方法と結果】アスパラガス葉より調製したmRNAから二本鎖cDNAを合成した。この二 本鎖CDNAをPCRの鋳型として用い、fructosyltransferaseとinvertaseとの間に相同性があ るという既報に基づき、既知の植物由来のフルクタン代謝関連酥素で高く保存されている 領域のアミノ酸配列をもとに合成したdegenerate primer を用いPCRを行い、フルクタン 代謝関連酥素と高い相同性を持つ767bpのPCR断片を得た。この断片をプロープとしてア スパラガス葉より搆筑したcDNAライブラリーからスクリーニングした結果、2201bpから なるCDNAを単離した。

このCDNAは610のアミノ酸からなるタンパク質をコードしており、植物由来フルクタン 合成酵素と高い相同性を示した。さらにこのcDNAを醉母 Pichia pastoris で発現させた組 み換えタンパク質の酵素活性の解析から、このcDNAは6 ${ }^{G}-\beta$-D-fructosylitransferaseをコー ドしていることを確認した。

1) N. Shiomi, Carbohydr.Res. , $96: 281-292$ (1981) 
放線菌 Thermobifida sp. MBL10003 由来マンノースイソメラーゼの精製、

$\mathrm{Aa}-15$ クローニングと大腸菌による発現

( ${ }^{1}\left(\right.$ 独) 食総研、 ${ }^{2}$ 明治製菓(株)ヘルス・バイオ研)

1 春見隆文、O ${ }^{1}$ 森 澄子、年佐藤右一、 ${ }^{2}$ 西澤耕治

【目的】マンノースイソメラーゼは遊離のヘキソースに作用する唯一の酵素であり、Dマンノースと D-フルクトース間のケト・エノール互変異性化反応を触媒する。これま で本䣼素に関する知見は少なく、均一にまで精製された報告例は極くわずかであり、ま た遺伝子解析が行われているのは Agrobacterium radiobacter 及び E.coli の醭素のみで ある。我々は、土壤中より単離された好熱性放線菌 Thermobifida sp. MBL10003 のマン ノースイソメラーゼを電気泳動的に均一になるまで精製し、その $\mathrm{N}$ 末アミノ酸配列を基 にして本酵素遺伝子をクローニングし、大腸菌による大量発現を試みた。

【方法と結果】培養菌体抽出液を各種の疎水、陰イオン交換及びゲル滤過クロマトグラ フィーにより精製し、SDS-PAGE で 41kDa の単一バンドを得た。本精製酵素及びその 消化断片を PVDF 膜にブロッティングし、N 末アミノ酸を決定した。これを基にプライ マーを作成し、PCR, TA クローニングを行って部分配列を決定した。次に5'及ひ3 側未 知領域を解析するため TAIL-PCR を行い、全塩基配列を決定した。本醭素遺伝子は 1221 塩基対、 407 残基アミノ酸をコードしており、72.1\%と高い GC 含量を示した。そのた め、通常の PCR では増幅断片を得ることができず、プライマー、温度条件、ポリメラ 一ゼ等の条件検討を必要とした。本遭伝子を発現ベクターpET30に組み込み発現用プラ スミドを調製し、大腸菌(E.coli BL21Gold)に導入し形質転換した。得られた大腸菌体破 砕可溶画分の酵素活性は 7550U/ wet cell であり野生株のそれの約 750 倍を示した。

\section{Aa-16 サッマイモ ADP グルコースピロフォスフォリラーゼ ラージサフユニット通伝子の RT-PCR 解析 \\ （鹿児岛大甞・生物资源化学）○有留友洋・北原英文・菅沼俊彦}

【目的】ADP クルルコースピロフォスフォリラーゼラージサフユニット (AGPaseL)

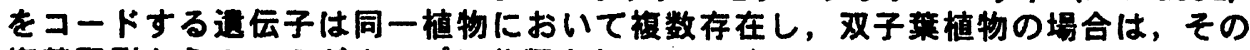
熄基配列から 3 つグループに分積されているい。サッマイモではそのうちの一 つ(グループ1)か報告されている゙のみであるため，本研究では，他の AGPaseL 这伝子を梌索するとともに，各运伝子の轱写についてRT-PCR 解析を行った。

【方法】サッマイモは普及品種のコカネセンガンを用いた。3つのグループの AGPaseL 通层子について，それぞれサッマイモまたはジャカイモの既知通伝子を 考にしてプライマーを作成した。枟写量は RT-PCR 法により調ペ, 錆型にはカ ルス，塊根，葉から調慗したトータル RNAを用いた。

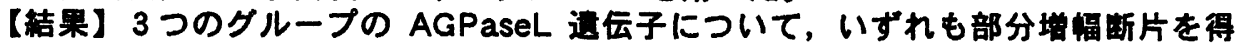
ることができた。グループ 1 に后する迹层子は，いずれの器官でも予湘断片長の 增幅産物が得られたか，その塩基配列はカルスでのみ異なっていた。また，双方 で相同性の低い部分から改めてプライマーを作成して分別增媪を試みたところ， 両者は各器官における発現吾が異なることが示唆された。さらに,グループ 2 と グループ 3 の部分塩基配列を得ることに成功した。グループ 3 AGPaseL 造伝子 は葉でのみ增崰産物が得られ，ここでも器官特異的発現が示睃された。これら4

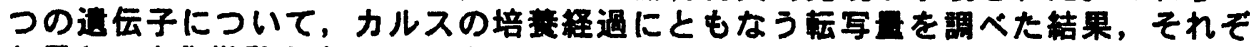
れ異なる変化挙動をすることが分かった。

1) Harn et al., Plant Cell Physiol., 41, 1235-1242 (2000). 


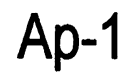

$\mathrm{X}$ 線結晶構造と部位特異的変異法を用いた好熱性放線菌 $\alpha$-アミラ 一ゼ (TVA I 、TVAII) のシクロデキストリン認識機構の研究 (農工大生命工、*農工大応生科)

○大滝証、“水野正浩、井口晃弘、*殿塚隆史、*坂野好幸、神鳥成弘

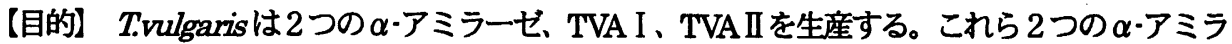
一ゼのうち、TVAII は通常の $\alpha \cdot$-アミラーゼが加水分解することのできない、環状オリコ糖であるシ クロデキストリン(CD)を加水分解できる。一方、TVA I は CD をほとんど加水分解できない。TVA I 、TVA II 及ひ不活性型 TVA II / $\beta-\mathrm{CD}$ 基質複合体の X 線結晶解析の結果、TVA I の活性部位に おいて Phe313が CD 結合阻害に、Trp398 が直鎖状基質認に関与し、TVAIIにおいては Phe286、 Tyr45 がCD 認識に関与していると考えられた。そのため本研究では、部位特異的変異道入法を用 いてこれらの残基を他のアミノ酸に置換し、その反応動力学的パラメータの測定を行うことで、こ れらの残基の役割を明らかにし、両醭素間で基質特異性の異なる理由について考察を行った。

方法】部位特異的変異法を用いて、TVA I の Phe313 を Ala (F313A)、Trp398 を Ala (W398A)、 Val (W398V) に、TVAIIの Phe286 を Ala (F286A)、Tyr (F286Y) に、Tyr45 を Ala (Y45A) にそ れぞれ置換し、反応動力学的パラメータの測定を行った。

【結果】反応動力学的パラメー夕の測定結果、TVA I の変異型醭素 F313A は $\alpha-\mathrm{CD} 、 \beta-\mathrm{CD}$ に対 する醭素活性の上昇が、W398A、W398Vにおいてはデンプンに対する活性の低下がみられた。一 方、TVA IIの変異型酳素はF286A、Y45A は CD に対する活性の低下がみられ、これらの残基か唡 醭素間の基質特異性の相違に起因する残基であると考えられた。

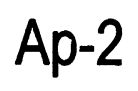

Thermoactinomyces vulgaris $\mathrm{R} \cdot 47 \boldsymbol{\alpha}$-amylase II (TVA II) $の$ Pullulan model oligosaccharide を用いた複合体 X 線結晶構造解析

（農工大応生科、*農工大生命工）○水野正浩，“大滝証、田辺義拓、 *安部晊美、殿塚隆史、神鳥成弘、西河淳、坂野好幸

【目的】T. vulgaris R-47 の生産する $\alpha$-アミラーゼ II(TVA II)は、デンプンのみならずプ

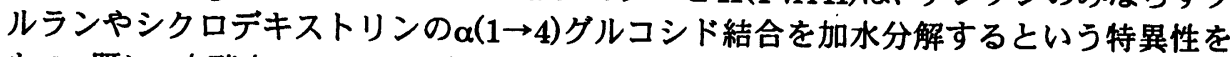
もつ。既に、本酳素の及・シクロデキストリンとの複合体構造は明らかにされており、様々

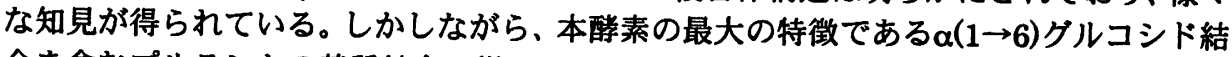
合を含むプルランとの基質結合の様子は明らかにされていない。そこで、本研究ではプ ルランの部分加水分解産物である 6 糖のパノシルパノースを用いて、触媒残基に変異を 導入した D325N 変異型醭素との複合体構造の X 線結晶構造解析を試みた。

【方法・結果】プルランを TVA により部分加水分解させ、HPLC により分取、精製し たパノシルパノースの $10 \mathrm{mM}$ 溶液に対して、D325N の結晶を 12 時間ソーキングさせ た。その後、シンクロトン放射光(PF, BLi8B)を用いて反射強度測定を行った。テータ 解析により、分解能 $2.2 \AA$ にて明瞭な基質の電子密度が得られた。その結果、取り込ま れた基質の加水分解点よりも還元末端側のグルコース(+1)残基の C-1,C-4, C-6 位の水酸 基は、全てグルコシド結合が観測され、枝分かれてしていることが分かった。これは、 パノシルパノースが分解された後に、別のパノースに転移させ生じた糖転移産物である と考えられる。現在、更なる解析を行っているところである。 


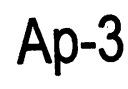

\author{
ネオプルラナーゼの立体構造と基質特異性 \\ （'阪大·蛋白研、 ${ }^{2}$ 江崎グリコ·生化研） \\ ○本同宏成
}

【目的】ネオプルラナ一ゼは $\alpha-1,4$ 及び $\alpha-1,6$ グルコシド結合を共に加水分解可能な酵素である。ま た本酽は、アミロース、シクロデキストリン、プルランなど様々な基質に対して作用することが出来 る。これまで X 線結晶構造解析により立体構造上ダイマ一を形成していることが判明している。本研 究では様々な基質複合体の結晶構造解析を行い、ネオプルラナーゼの基質特異性を明らかにする ことを目的とする。

【方法】ネオプルラナーゼ単体、及びパースとの複合体、また变異体とマルトテトラオース、イソパ 一スとの複合体の計4種の結晶について構造解析を行つた。デー夕収集は SPring8BL40B2 で行い、 それぞれ 1.9、2.4、2.8、3.0A分解能で構造を決定した。

【結果】構造解析の結果、4つのサブサイトが明らかとなつた。立体構造上、活性部位の非還元末端 側には2つのサブサイトが存在する(-1、-2)。またサブサイト-3に対応する位置には近接する醉素 の構造はなく、活性クレフトは外に大きく開かれていた。このことによりプルランのような $\alpha-1,6$ 結合 を含む基質が立体障害なしに酵素に結合できることが分かった。またマルトテトラオース複合体の 構造では、サブサイト+1のグルコ一スに対して水素結合は一対しかなく、疎水的な環境であることが 分かった。イソパノース複合体の構造ではサブサイト+1の糖結合位置が若干異なっており、このよう な基質結合部位の㖟昧さには疎水的な環境が影響していると考えられる。またマルトテトラオース が結合する際、ダイマーを形成している相手分子のループが約 $5 \AA$ 動き、induced fit していることが 明らかとなった。

\title{
Ap-4 \\ Crystal structure and oligomeric state of Cyclomaltodextrinase (CDase) from alkalophilic Bacillus sp. I-5 \\ (Dept. of Food Science \& Technology, Seoul National University, and 1Dept. of Life Science, Pohang University of Science and Technology) \\ H.S. Lee, M.S. Kim1, J.H. Choi, B.H. Oh1, and K.H. Park
}

The three dimensional structure of CDase from alkalophilic Bacillus sp. I-5 revealed that this enzyme forms a dodecamer which is a hexamer of the dimeric form observed for maltogenic amylase from Thermus strain and other related enzymes. Oligomeric state of CDase I-5 was modulated by salt concentration and $\mathrm{pH}$ of the reaction buffer. Gel permeation chromatography and analytical ultracentrifugation analysis showed that dodecameric CDase I-5 dissociated to dimeric form at $\mathrm{pH} 6.0$ and the dimeric CDase I-5 associated to dodecamer at $\mathrm{pH}$ 7.0. The formation of the supramolecular assembly resulted in $\sim 10$ fold increase in the catalytic efficiency compared with dimeric unit of the enzyme. To investigate $\mathrm{pH}$-dependent dissociation/association process of CDase I-5, four His residues in the $\mathrm{N}$ - and $\mathrm{C}$-terminal regions were substituted with Val by site-directed mutagenesis. The mutant enzymes exhibited greater dissociation constants than those of CDase wild-type at $\mathrm{pH}$ 6.0. The wild-type enzyme did not dissociate to dimer at $\mathrm{pH} 7.0$ whereas the mutant enzyme, H49V/H89V/H539V/H547V existed in dimer-dodecamer equilibrium. 


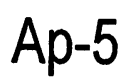

カルシウムを含まない $\alpha$-アミラーゼの耐熱化

萩原浩、五十嵐一暁、○林康弘、北山香織、遠藤圭二、 小澤忠弘、尾崎克也、川合修次、*伊藤進

(花王（株）生物科学研究所、*海洋科学技術センター)

【目的】好アルカリ性 Bacillus sp. KSM-K38 株由来のカルシウムを含まない新

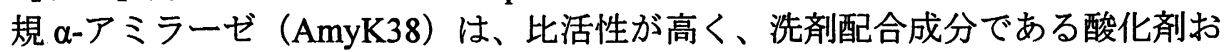
よびキレート剂に対して非常に安定な酵素である ${ }^{1,2)}$ 。しかし、本酵素は熱に 対しては比較的不安定であったので、工業的応用面を拡充する目的で、蛋白質 エ学による耐熱化を試みた。

【方法および結果】AmyK38 と Bacillus 由来 $\alpha$-アミラーゼ（AmyK）の耐熱性 変異酵素（dRG）との間で数種のキメラ酵素を構筑したところ、AmyK38 の N 末端側 19 アミノ酸配列を $\mathrm{dRG}$ の配列に置き換えたキメラ酵素に耐熱性の向上 が認められた。その結果、AmyK38 は Tyr11 $\rightarrow$ Phe 変異によって耐熱性を獲得す ることが判明した ${ }^{3)}$ 。一方、AmyK38 のドメイン B 中の $\beta$ ターン部位に

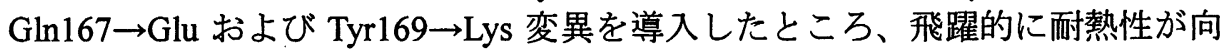
上した。これら二つの変異と $\mathrm{N}$ 末端置換変異を組み合わせ、優れた酵素特性を 失うことなく、耐熱性を更に向上させることに成功した。

1) H. Hagihara, et al., Appl. Environ. Microbiol., 67, 1744-1750 (2001)

2) H. Hagihara, et al., Eur. J. Biochem., 268, 3974-3982 (2001)

3) H. Hagihara, et al., J. Appl. Glycosci., in press

\section{Ap-6

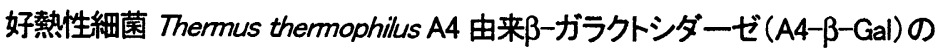 高活性型酵素の X 線結晶構造解析}

('東大院農·応生工, ${ }^{2}$ よつ葉乳業(株)・リサーチセンター, ${ }^{3}$ 青森大·エ) O日高將文 ${ }^{1}$, 伏信進矢 ${ }^{1}$, 大津奈穂美 $^{2}$, 元島英雅 $^{2}$, 松澤 洋 ${ }^{3}$, 祥雲弘文 ${ }^{1}$, 若木高善 ${ }^{1}$

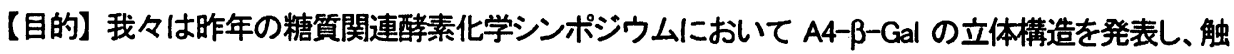
媒ドメインとして TIM バレル構造を持つ酵素であることを報告した。本醭素は薬剤を用いたランダム 突然変異誘起処理により、プロリン 317 番がセリン、ヒスチジン323番がチロシンに変異し、比活性が 2 倍以上に高〈なった高活性型酔素が得られている ”これらの変異は活性中心ポケットを形成する $\beta-7 、 \alpha-7$ 間のループの付け根に導入されている。本研究では活性の上昇と立体構造の相関を調へ るため、高活性型 A4- $\beta-$ Gal のX 線結晶構造解析を行つた。

【方法】高活性型 A4- $\beta-$ Gal は大腸菌を用いて発現し、野生型 A4- $\beta-$ Gal と同様の条件で精製、結晶 化を行つた。X 線回折データ測定は、シンクロトロン放射光(KEK-PF)で行つた。

【結果】高活性型A4- $\beta-G a l$ の立体構造は、現在分解能 $2.8 \AA$ で明らかにしている。野生型醭之構 造を比較したところ、主鎖構造に大きな違いは見られなかったが、基質結合ポケットが広がっていた。 また、基質結合ポケット入りロに存在する $\alpha$-ヘリックスが動いており、これらが活性の上昇に関わっ ていると考えられる。現在、より高分解能の構造、および基質複合体構造の解析を目指している。

1) 大津奈穗美ら；農芸化学会 2001 年大会講演要旨集 (p. 313) 


\section{Ap-7 \\ 新規サイクロデキストラン生産菌の特性 \\ （独法・食総研, 翔南製糖(侏) \\ O冓根和美，寺瀑和惠，宮城䞟 ', 宮城貞夫'，小林幹彦}

【目的】サイクロデキストラン(CI)は, グルコ一スが $\alpha-1,6$ 結合でつながつた渨状オリゴ榶で, 強い 抗う蝕作用を有する。これまで Cl生産菌は, Bacillus circulans T-3040 株およびし155 株の 2 種 類のみが報告されており, これらの苜株はいずれも $\mathrm{Cl} 7, \mathrm{Cl}-8, \mathrm{Cl}-9$ の 3 種類を中心に生産する。

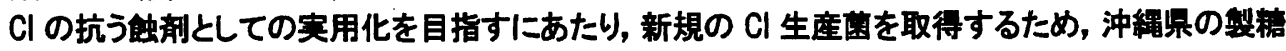
エ場内よりスクリーニングを行った。

【方法】サンプルを $0.2 \%$ ブルーデキストランを含む固体培地に染抹し, ハロ一を形成する图を分

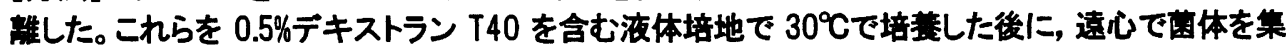

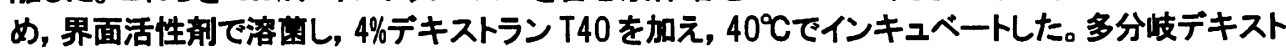
ラン水解䤑素て直鎖オリゴ糖を分解した後に TSK gel Amide-80 カラムを用いて HPLCにより残存

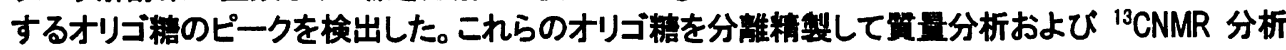
により檴造を決定した。

【結果】多分吱デキストラン水解醉素で分解されないオリゴ糖を生産する图株を4株分離したが, すべて Cl-9 よりも分子量の大きいオリゴ糖を中心に生産した。これらの图株のうち, オリゴ糖生産 量が多い 860K 株および 350K 株について图の同定を行った結果, いずれも Bacillus 属图であっ た。筫量分析および ${ }^{13} \mathrm{CNMR}$ 分析により, 860K 株はグルコース 10 個, 11 個および 12 個の環状才 リゴ榕 Cl-10, Cl-11， Cl-12を生産していることが明らかりなった。 Cl-10およびCl-11は, Cl-7, Cl-8, Cl-9 同様 Leuconostoc 属のデキストランスクラーゼ, Streptococcus 属のグルコシルトランスフェラ 一ゼに対する阻害効果が認められ，抗う蝕作用を有することが示唆された。

\section{$\begin{array}{ll}\text { Aporosarcina globispora N75 株由来の環状四糖生成酵素 } \\ \text { Ap-8 } & \text { (林原生化研) O丸田和彦, 仲田哲也, 山下 洋, 久保田倫夫, }\end{array}$ \\ 福田恵温, 栗本雅司, 辻阪好夫}

【目的】新たに単離したSporosarcina globispora N75 株由来の環状四糖生成に関与する 2 種類 の酵素 1,6- $\alpha$-glucosyltransferase (6GT)と $\alpha$-isomaltosyltransferase (IMT)をそれぞれ精製し諸 性質を調へること、また両酵素遗伝子の塩基配列決定し、一次構造を明らかにすること。

【方法および結果】N75 株の培養上清を硫安塩析、各種クロマトグラフィーに供して両酵素を電 気泳動的に単一まで精製し諸性質を調べた。6GTは反応至適 pH 6.0 6.5、pH安定性 5.5 9.0、 反応至適温度 $50^{\circ} \mathrm{C}$ であり、既報の $\mathrm{C} 11$ 株由来 $6 \mathrm{GT}^{1)}$ の反応至適温度 $45^{\circ} \mathrm{Cl}$ 比へ $5^{\circ} \mathrm{C}$ 高かった。 IMT は反応至適 $\mathrm{pH} 6.0 \sim 6.5 、 \mathrm{pH}$ 安定性 4.5 10.0、反応至適温度 $50^{\circ} \mathrm{C}$ であった。両酵素の温 度安定性はC 11 株の両酵素よりいずれも $5^{\circ} \mathrm{C}$ 高く、50ํまで安定であった。両酵素遗伝子を含む 8627 bp DNA 断片をクローニングし全塩基配列を決定した。6GT は分泌シグナル 35 残基を含む 1286 アミノ酸残基(分子量 $138,409 \mathrm{Da}$ )、IMT は分泌シグナル 29 残基を含む 1093 アミノ酸残基 (分子量 119,800 Da)であることがわかった。アミノ酸配列は、C11 株由来酵素の配列 ${ }^{2)} に$ 対して $82 \%(6 \mathrm{GT}), 85 \%$ (IMT) と高い相同性を示し、 $\alpha$-glucosidase family II $の$ 共通配列も保存されて いた。両酵素遺伝子は N75 株のゲノム上で近接して配置されており、直ぐ上流の未知遺伝子と 共にオペロン様構造を形成しており、C11 株の cts(環状四糖関連)オペロンの構造と類似してい た。N75 株の酵素を用いた、液化澱粉からの環状四糖製造についても併せて報告する。

1) Nishimoto, T., et al. Biosci. Biotechnol. Biochem., (in press).

2) Aga, H., et al. Biosci. Biotechnol. Biochem., 66, 827-838 (2002). 


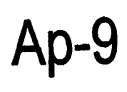

Bacillus sp. NRRL B21195 が分泌する cyclo-alternan(環状 4 糖) 合成に 関与する 2 つの酵素に関する研究

（食総研, ' USDA）○金 然桂、北岡 本光、林 清,

Jeffrey A. Ahlgren ${ }^{1}$, Gregory L. Cote ${ }^{1}$

[目的] Bacillus sp. NRRL B21195の分泌する cyclo-alternan forming enzyme (CAFE)は alternan $[p o l y\{\rightarrow 6)-\alpha-D-G l c p-(1 \rightarrow 3)-\alpha-D-G l c p-(1 \rightarrow\}]$ よ $り$ cyclo-alternan (CA) $[c y c 10\{\rightarrow 6)-\alpha-D-G|c p-(1 \rightarrow 3)-\alpha-D-G| c p-(1 \rightarrow 6)-\alpha-D-G \mid c p-(1 \rightarrow 3)-\alpha-D-G I c p-(1 \rightarrow\}]$ を合 成する酵素として発見された ${ }^{1)}$ 。また、本酵素パノースから i somal tosyl panose の中間体 を経て、al ternanから合成するよりも早い速度でCA を合成することが報告された ${ }^{2)}$ 。CAFE は isomal tose-agarose によるアフィニティークロマトグラフィーにより培養上清から一 段階で SDS-PAGE 上二本の蛋白バンド(DE，140 kDa；CAFE，120 kDa)まで容易に部分精製す ることができる。本研究の初期において、この部分精製酵素がマルトオリゴ糖から直接 CA を合成することを見いだした。そこで、CA 合成に関与する両タンパクの役割を解析した。 [万法及び結果]濃縮培養上清から 2 つ酵素（DE, CAFE）を精製し、両酵素の基質特異性を 調べた。CAFE 単独ではマルトオリゴ糖には作用しなかった。DE 単独ではパノースには作用 しないが、マルトオリゴ糖に対して非還元末端グルコシル基を分子間 1.6 転移する活性を 示し、非還元末端にパノース構造を持つオリゴ糖を合成した。CAFE はパノースだけでなく DEにより合成されるオリゴ糖を基質としてCAを合成する活性を示した。以上の結果から、 CAFE は本質的には al ternan からCA を合成する酵素ではなく、DE-CAFE の共同作用により デンプンからCA を合成する酵素系のひとつであることが示唆された。

1) Gregory L. Cote and Peter Biely, Carbohydr. Res. 226, 641-648 (1994).

2) Gregory L. Cote and Jeffrey A. Ahlgren, Carbohydr. Res. 332, 373-379 (2001).

\section{Ba-1 ニホンミツバチ (Apis cerana Japonica) 由来 $\alpha$-Glucosidase I の精製と諸性質 ('北大院農·応生科、 ${ }^{2}$ 日本食品化工(侏)、 ${ }^{3}$ 福島県立博物館) \\ O山本 健 ${ }^{1.2}$ 、Jintanart Wongchawalit ${ }^{1}$ 佐治 靖 $^{3}$ 、森 春英 ${ }^{1} 、 千$ 葉 誠哉 ${ }^{1.2}$ 、 木村 淳夫 ${ }^{1}$}

【目的】これまで、セイヨウミツバチ(Apis mellifera L.)には、3種の $\alpha$-glucosidase アイソザイム ( HBG I, II, III ) が存在し，その構造と諸性質について検討してきだ。今回，トウヨウミツバチの

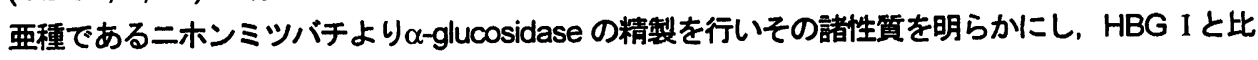
較することを目的とした。

【方法と結果】福島県山中に生息するニホンミツバチ $1 \mathrm{~kg}$ を緩衝液中で破砕し，遠心分離で得 られた上清を粗醇素抽出液とした。本抽出液を 95\%飽和硫安沈殿後，塩析クロマトグラフィーを 行い, maltase 活性を高濃度硫安に可溶な画分と低濃度硫安に可溶な画分の2つの画分に分離した。 以後，高濃度画分に可溶なものを $\alpha$-glucosidase I として，陽イオン交換クロマトグラフィーそして ゲルろ過を用いて電気泳動的に単一になるまで精製した。本酵素の分子量は, SDS-PAGEにおいて 約 $82 \mathrm{kDa}$ であり, HBG I の分子量約 $98 \mathrm{kDa}$ より小さな值であった。本醭を endoglycosidase H にて処理したところ.7 kDaの分子量低下が見られたため, 糖タンパク質であることが示唆された。 現在，本醭の諸性質について検討を行っている。

* Nishimoto, M. et al. : J. Appl. Glycosci., 49, 191 - 197 (2002). 

Ba-2 Purification and Properties of $\alpha$-Glucosidase II from Japanese Honeybee, Apis cerana Japonica.
( ${ }^{1}$ Graduate School of Agr., Hokkaido Univ. , ${ }^{2}$ Nihon Shokuhin Kako Co., Ltd., ${ }^{3}$ Fukushima Prefectural Müseum)

\section{OJintanart Wongchawalitt, Takeshi Yamamoto ${ }^{1,2}$, Osamu Saji ${ }^{3}$, Haruhide Mori ${ }^{1}$, Seiya Chiba ${ }^{1,2}$, and Atsuo kimura ${ }^{1}$}

We have been reported that there were three kinds of $\alpha$-glucosidase isozymes (HBG I, II and III ) in European honeybee ( Apis mellifera L. ). In this study, $\alpha$-glucosidase II (JBG II ) from Apis cerana J. was isolated and characterized to be compared with HBG II. JBG II was purified as homogeneous protein through the steps of a salting-out chromatography, where the JBG II was eluted at the low concentration of ammonium sulfate, anion and cation exchange columns, Sephacryl S-100 and hydrophobic chromatographies. The last step gave the total protein of $162 \mathrm{mg}$, the total activity of 1400 unit, the specific activity of 8.6 unit/mg and the purification fold of 55.4. The molecular weight of purified enzyme was estimated to be $86 \mathrm{KDa}$ on SDS-PAGE. Deglycosylation of the enzyme with endoglycosidase $\mathrm{H}$ gave $71 \mathrm{kDa}$ on SDS-PAGE, indicating that the JBG II was a glycoprotein. The $\mathrm{N}$-terminal amino acid sequence was similar to HBG II. The further, properties, such as the effects of $\mathrm{pH}$ and temperature, and substrate specificity of JBG II will be reported.

\section{Ba-3 セイヨウオオマルハナバチ由来の $\alpha$-Glucosidase II の精製と諸性筫 (北大院農·応生科) \\ O高橋 有志、鳥羽瀬 輝、森 春英、千葉 誠哉、木村 潡夫}

【目的】我々はこれまでに、セイヨウミツバチ (Apis mellifera L.) に3種の $\alpha$-glucosidase アイ ソザイム (HBG I, II, III) の存在を確苑し、その機能と構造を明らかにしてきた。本研究ではセイヨ ウオオマルハナバチ (Bombus terrestius L.) の $\alpha$-glucosidase (BBG) について機能と構造を調へ、 HBG との比較を目的とした。BBG I はHBG Iに相当することが明らかになった。今回、新たにBBG Пの諸性筫を調べたので報告する。

【方法と結果】成虫の抽出液を salting-out chromatography に供した際、2 2 つ活性画分に分離 した。このうち低濃度硫安に可溶な画分より、DEAE-Sepharose CL-6B、CM-Sepharose CL-6B、 Bio-Gel P-100 およびBUTYL-TOYOPEARL 650M を用いて精製し、電気泳動的に単一な醉素標品 (BBG II) を得た。精製醭の分子量は65,000、至適 pHは5.1、pH および温度に対する安定域は それぞれ pH4.9-9.5 (5ㄷ、24 時間)、37゚ Cまで (pH5.1、15 分間) であった。 maltooligosaccharide、 p-nitrophenyl $\alpha$-glucoside、sucrose に対する $K_{m} や k_{0}$ はBG III比べて極めて高いか、 反応効率 $\left(k_{0} / K_{m}\right)$ はほぼ同等の值であった。HBG II の N 末端配列の相同性はHBG I、II および且に対して それぞれ 59、88、47\%であった。以上の結果から精製したマルハナバチa-glucosidase II はミツバ チ $\alpha$-glucosidase IIに対応する酻素であると判断された。 
Ba-4

赤米 $\alpha$-Glucosidase 一発芽および末発芽種子中の酔素の比較一

(北大院農·応生科)

○中井 博之、森 春英、千葉 誠哉、木村 淳夫

【目的】我々は、イネ品理(新雪、オンネモチ、日本晴、黑米、赤米)の未発芽種子より $\alpha$-glucosidase を精製し、それらの諸性質を明らかにしてきた。今回、赤米発芽種子で発現する $\alpha$-glucosidase を 見出し、醇化学的諸性質を解析した。未発芽種子中の酻と比較を行つたのて報告する。

【方法と結果】赤米種子を $30^{\circ} \mathrm{C} 、$ 暗所て発芽させた。 $\alpha$-glucosidase 活性は吸水後直ちに上昇し、 3日目には未発芽時の約 10 倍まで増加した。この発芽時における活性の経時変化は、他のイネ品 種では確認されなかった。赤米発芽種子から酻素を抽出し、各喠カラムクロマトグラフィー (CM-Sepharose CL-6B、Sephadex G-100) に供し、電気泳動的に単一な酻桑標品を得た。精製醇 絜の分子量は $94 \mathrm{kDa} 、 \mathrm{pH} 4.0 、 45^{\circ} \mathrm{C} て ゙$ 最大活性を示し、 $\mathrm{pH}$ およひ温度に対する安定域はそれそれ $\mathrm{pH}$ 3.5-10.5 (4 $\left.{ }^{\circ} \mathrm{C} 、 24 \mathrm{~h}\right) 、 50^{\circ} \mathrm{C}$ 以下 $(\mathrm{pH} 4.0 、 15 \mathrm{~min})$ であった。末発芽璉子中の $\alpha$-glucosidase と比較して、maltose、isomaltose、phenyl $\alpha$-glucoside、soluble starchに対する親和性および分子 活性か高く、等電点、内部アミノ酸配列およひイ゚プチドマップにおいても莩いが見られた。以上の 結果から、発芽およひ失発芽種子中の酥素が異なる遺伝子産物であることが分かった。

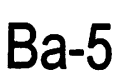

Study on two active forms of $\alpha$-glucosidase from yellow dent corn.

OMee SON, Haruhide MORI, Seiya CHIBA, Atsuo KIMURA

Division of Applied Bioscience, Graduate School of Agriculture, Hokkaido University

[Purpose] A several plant $\alpha$-glucosidases have been studied until now and some of them shch as rice and spinach enzymes have been reported to have several active forms. We found that two active forms (ydcg-l, ydcg-lt) of $\alpha$-glucosidase were also in yellow dent corn and some characteristics were examined to compare them each other.

[Results] Change of $\alpha$-glucosidase activity in corns was traced through developing and germination stages. In the com growing up in the field, $\alpha$-glucosidase activity was rapidly produced as the corn had reached over $20 \mathrm{~cm}$ and kept increasing as the fruit got ripe. During germination, the activity got reached the highest after 2 days of imbibition and decreased while $\alpha$-amylase was produced. Ydcg-t and ydcg-H were purified from dried seeds. The two active forms were seperated on CM-Sepharose and Butyl-TOYOPEARL chromatographies. The moleular weights of $y d c g-l$ and ydcg-ll were estimated to be 86,000 and 92,500 , respectively, by SDS-PAGE. The hydrolytic activities on various substrates were examined. Both of ydcg-I and II showed high activities toward maltose, nigerose and kojibiose but low activity toward isomaltose. Transglucosylation was investigated. The both enzymes catalyzed the formation of panose, kojibiose and predominantly maltotriose from $58.5 \mathrm{mM}$ of maltose. This result suggests that these enzymes act as an $\alpha-1,4$-transglucosidase. $N$-terminal sequences of the two active forms were the same. The structural difference will be expected and examined. 
Ba-6

系状菌 Acremonium implicatum IFO30538 由来 $\alpha$-Glucosidase の精製と諸性質

('日本食品化工(侏)、'北大院農·応生科)

山本 健 ${ }^{1,2}$ 、海野 剛裕 ${ }^{1} 、$ O渡息 純未 1 、山本 幹男 ${ }^{1}$ 、森 春英 ${ }^{2}$ 、

千葉 絾哉 ${ }^{1,2}$ 、木村 淳夫 $^{2}$

【目的】 $\alpha-1,3-$ グルコシド結合を有するニゲロースやニゲロシルマルトオリゴ糖は，免疫賦活作 用*などの生理機能を有する有用オリゴ糖の一つである。今回, 本オリゴ糖生産能をもつ系状菌 Acremonium implicatum IFO30538 由来の $\alpha$-glucosidase の精製を行い，その諸性質を明らかにする ことを目的とした。

【方法と結果】培養上清より，菌体外に分泌される $\alpha$-glucosidase を陰イオン交換およひ柾水ク ロマトグラフィーそしてゲルろ過を用いて，native-PAGE で単一になるまで精製した。本酽素は， SDS-PAGEにより $51 \mathrm{kDa}$ および $60 \mathrm{kDa}$ のへテロ 2 量体であることが明らかにされ，ゲルろ過に おいて $440 \mathrm{kDa}$ のため, ヘテロ8量体であることが示唆された。本酵素の至適 $\mathrm{pH}$ は 7.0 であり， p Hおよび温度安定域は，それぞれp H6.0-11.0，45 ํ以下であった。本醭素の各種基質に対す る加水分解能をその V max により評価すると，ニゲロースに対し最も効率的に作用し，次いでマル トース、コージビオースの順であった。トレハロースやスクロースに対しては加水分解能を示さな かった。

*S. Murosaki, et al. : Biosci. Biotechnol. Biochem., 61, 439 - 442(1997)

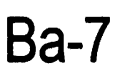

部位特異的变異 $\alpha$-グルコシダーゼの基筫特異性変化について （日大生猡科・湿化）

○中島康介、松石 紫、北川其衣、西郷紀行、小川其弘、星野重樹、 河内 隆、西尾俊幸、奥 忠武

【目的】我々は数種の $\alpha$-グルコシダーゼがデオキシ化基留や、水酸基の立体配置が異 なるジアステレオマー基筫に対しても作用できることを見い出し、報告してきた ${ }^{1}$ 2)。

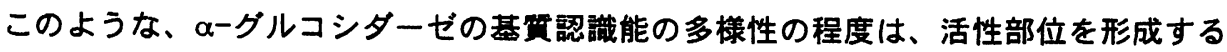
アミノ酸の種類に起因するものと考えられる。我々はこの部位のアミノ酸を特異的に变 換することにより、 現させることができるのではないかと考えた。

【方法及び結果】Bacillus stearothermophilus 由来 $\alpha$-グルコシダーゼをクローニング し、さらにメガプライマー法により数種の部位特異的变異酵素を作成した。これらの酻

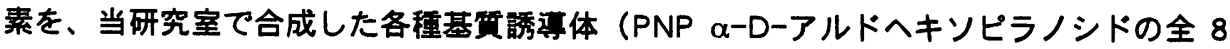
種類のジアステレオマー、モノデオキシ体、及びメトキシ体）に作用させ、变異醉素の 基䀧特異性の変化を調へた。酥素活性は、反応により遊離した $p$-ニトロフェノールの $405 \mathrm{~nm}$ における吸光度を測定することにより求めた。その結果、リコンビナント醉素 と変異醇素の間には活性や特異性に変化がるれた。

1)W. Hakamata, T. Nishio and T. Oku, Carbohydr. Res., 337, 629-634 (2002).

2)西尾俊幸、日本応用糖供科学会誌, 49, 45-55 (2002). 
Ba-8

大腸菌の Glycoside hydrolase family 31 様タンパク質の機能 （北大院農・応生科）

○奥山 正幸、森 春英、千葉 誠哉、木村 淳夫

【目的】大腸菌ゲノム上には glycoside hydrolase family 31 の酥菜とホモロジーのあるオ ープンリーティングフレーム (yicl、yihQ) が存在するが、その機能は明らかにされていな い。family 31 には a-glucosidase をはじめとして a-xylosidase や a-1,4-glucan lyase などが 含まれるが、大腸菌ではこれまでこれらの酥索は同定されていない。今回、我々はこれら 2 つの yicl、yihQのクローニングと発現を行い、その機能について調べた。

【方法と結果】 PCRにより yicl、yihQ 寈伝子をそれぞれ増幅した。これらの逪伝子産物

（Yicl、YihQ）の生産には大腸菌を宿主とし、pTrc99A 由来の発現プラスミドを用いた。 LB 培地中で $0.1 \mathrm{mM}$ IPTG により組み換え酥素の誘道を行った。超音波破砕により得られ た無細胞抽出液にはいずれの遺伝子の発現系でも $\alpha$-glucosidase 活性は検出されなかった。 Yicl は tamarind gum cellulase により処理した xyloglucan oligosaccharide mixture を基 質とした際に xylose を遊離することを確認し、a-xylosidase であることが解った。そこで Yicl 酵素を陰イオン交換、ゲル濾過、疎水の各種カラムクロマトグラフィーにより精製し、 醉素化学的な性質を調べた。分子量 88,000 (SDS-PAGE) 、反応の最適 pH は 7.1、醉素 は pH 4.7 から $10.1 、 47^{\circ} \mathrm{C}$ までの範囲で安定であった。xyloglucan oligosaccharide に高い 特異性を示し、p-nitrophenyl a-xyloside にもわずかに作用した。a-glucosideにはほとんど 作用しなかった。一方 YihQ は a-xylosidase および $\alpha-1,4-$ glucan lyase 活性も有さず、機能 は不明である。

\title{
Ba-9
}

\author{
紅趐菌グルコアミラーゼのマルトオリゴ榶に対する作用 \\ （鹿児島大湜・生瓷化） \\ ○小牧重文、营沼俊彦、北原兼文
}

【目的】紅趐菌（Monascus 属）は中国において古くから酒類、食品製造に広く用

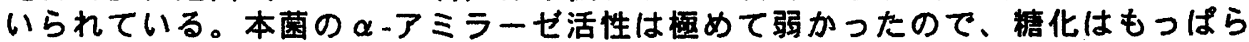
グルコアミラーゼによると考えられる。今回はグルコアミラーゼを精製し、重合 度 2-7までのマルトオリゴ糖に作用させた時の生成物と生成速度を調へ、マル チプルアタック並びにサブサイト親和カに関する情報を得た。

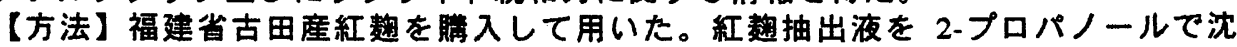
殿させ、DEAE-Toyopear1650M カラム、Superose-12 カラムでクロマトを行い、部 分精製紅靝グルコアミラーゼを得た。分解速度はグルコース・オキシダーゼ法で 生成物分布は HPAEC-PAD 法で測定した。

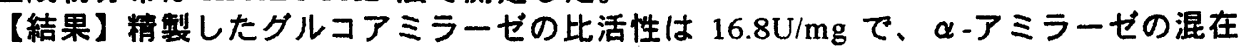

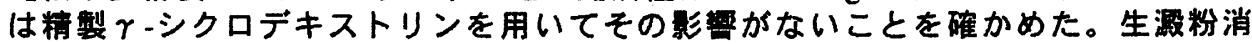
化性は他起源の市販グルコアミラーセにに比へ著しく低かった。G 5，G6，G 7 では重合度が元より 2 つ小さいオリゴ糖が反応初期から模出されマルチプルアタ ックが観測された。速度パラメータは経時変化を 2 次関数として処理した初速度 を用い、ノンリニアの最少自乗法で求めた。得た速度パラメータを用いることに より、サブサイト親和カ A1〜A7 は、-0.46、4.91、1.18、0.49、0.33、-0.09、0.24kcal $/ \mathrm{mole}$ と評価された。 


\section{Costridium thermoamylolyticum グルコアミラーゼ遺伝子のクローニング \\ およひ大腸菌発現}

（北大院・農·応生科）

○森本奈保喜、早瀬友美、安川嘉敬、磯野值人、平賀勧、伊藤浩之、松井博和

【目的】グラム陽性土壤細菌である Arthrobacter globiformis 142 は、デキストランを唯一の炭 素源として培食すると、菌体外にグルコデストラナーゼを誘導的に生成する。本研究室ではこれ までに A. globiformis 142 の生産するグルコデキストラナーゼをコードする遺伝子の全塩基配列 を決定した。推定されるアミノ酸配列は Costridium sp.およひ Thermoanaerobacterium thermosaccharolyticum 由来のグルコアミラーゼと約 37\%の相同性を示した。また、その配列 中にはグルコアミラーゼの活性中心に保存されている配列が見られ、両醭素間には何らかの類緑関 係があることが示唆された。そこで、両酵素を複合的に解析することを目的として、C thermoamylolyticum グルコアミラーゼ遺伝子のクローニングおよひ大腸菌発現を行ったので報 告する。

【方法および結果】既知の Clostridium 属由来グルコアミラーゼ遺伝子の配列を基にプライマー を作製し、PCR により本酵素をコードする遺伝子を取得した。推定アミノ酸配列は前述の Costridium 属グルコアミラーゼと $82 \sim 84 \%$ 、Arthrobacter 属グルコデキストラナーゼと 39\%の相同性を示した。大腸菌における発現酵素を電気泳動的に均一に精製し、醭素特性を調べ た。マルトースを基質に用いた場合、至適 $\mathrm{pH}$ は 4.5、安定域は pH $3.5 \sim 9.0$ 、至適温度およ び温度安定性はそれぞれ $65^{\circ} \mathrm{C} 、<60^{\circ} \mathrm{C}$ であった。また、 $K_{\mathrm{m}}$ および $V_{\max }$ の解析から、本醥素 は糸状菌由来グルコアミラーゼに比ベイソマルトースにより強く作用することがわかった。

\section{$\mathrm{Ba}-11$}

\section{系状菌の産生する生玢分解 $\alpha$-アミラーゼの一次構造の解析}

(大阪市立大・理学研究科 1 福山大・生命工学部 2 )

O松原孝宜 ${ }^{1}$ Ben Ammar Youssef ${ }^{1}$ 山本 覚 ${ }^{2}$ 伊藤和央 ${ }^{1}$ 飯塚 勝 ${ }^{1}$ 南浦能至 ${ }^{1}$

【目的】Aspergillus awamoriKT-11 株は生港粉分解能を有する $\alpha$-アミラーゼ（AmyliII）を産 生する。そこで, 本菌株の産生する 2 種類の $\alpha$ ・アミラーゼ (Amyl I およびAmylIII) および 1 種類 のグルコアミラーゼ（GA I ）のクローニングを行い，タンパク質の全一次構造を明らかにした。

【方法】本菌株の産生する Amyl I , Amyl一I]および GA I の 3 種類のアミラーゼの一次構造は, A awamoriKT-11 から mRNA を調製し RT-PCR 法によりクローニングを行い，その塩基配列と ともにコードされるタンパク質の全一次構造を決定した。

【結果】Amyl I の cDNA は全長 1,638 bp で，499 残基のアミノ酸をコードする ORF を含み, その一次構造は Aspergillus 属の $\alpha$-アミラーゼと高い相同性を示した。また, GA I のcDNA は全 長 2,113 bp で, 638 残基のアミノ酸をコードする ORF を含み, その一次構造もAspergillus 属の グルコアミラーゼと高い相同性を示した。Amylm/ $\mathrm{cDNA}$ は全長 2,087 bp で, 634 残基のアミノ 酸をコードする ORF を含み, その一次構造は $\alpha$-アミラーゼの活性中心を形成する 4 ヶ所の保存領 域，そしてセリン，トレオニンを多く含む領域が存在していた。また，Amyl I およびGA I と比 較すると, AmyliIIのタンパク質一次構造は N 末端則に Amyl I に類似する $\alpha$-アミラーゼドメイン を，そして架橋として働く TS 領域ののち，C 末端側には GA I の生揤粉吸着ドメインと高い相同 性のある領域が存在している，ハフブリット構造をしていた。 


\section{Ba-12}

アミロースとアミロペクチンに対して異なる特異性を示す $\alpha$-アミラーゼファミリー の䣼について

（江崎グリコ・生化研）

○釜阪 寬、杉本和久、大段光司、高田洋樹、西村隆久、栗木 隆、岡田茂孝

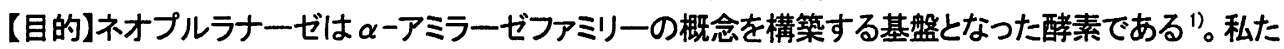
ちは、本酵素がアミロース及びアミロペクチンに対して異なる特異性を示すことを報告してきた2。。今回、 $\alpha$-アミラーゼフアミリーに属する幾つかの醅素についても同様の特異性を見出したので報告する。

【方法·結果】ネオプルラナーゼをアミロースあるいはアミロペクチンに作用させ、還元カの上昇および 反応生成物を調ベた。その結果、ネオプルラナーゼはアミロ一スを効率良く分解してマルトースを主に 生成したが、アミロペクチンを基質にした場合の還元力の上昇は殆ど見られなかった。馬鈴著澱粉に ネオプルラナーゼを作用させた場合、生成物中にはアミロペクチン画分のみが残存した。更に、この アミロペクチン画分の重量平均分子量変化を光散乱法で分析した。その結果、1 $0^{8} \mathrm{Da}$ 以上であった分 子量が、ネオプルラナーゼ処理により僅かに減少し、107Da程度になっていることが解った。アミロペク チンの鎖長には変化が認められなかったことよ以、澱粉のクラスター単位は変化していないと考えら れた。同様の特異性が cyclomaltodextrinase 及び maltogenic amylase についても認められたが、 $\alpha$ アミラーゼや $\boldsymbol{\beta}$ ーアミラ一ゼ等の醭素では全〈認められなかった。アミロース及びアミロペクチンに対し て異なる特異性を有する䣼素は、 $(\beta / \alpha)_{8}$ ーバレル構造からなる触媒ドメインのN末端側に約 120 アミ酸 残基からなるN-ドメインが共通して存在しており 当、このドメインの存在と上記特異性との関与が推定 される。

1) Takata, H. et al. 1992. J. Biol. Chem. 267: 18447-18452.

2) Kamasaka, H. et al. 2002. Appl. Environ. Microbiol. 68: 1658-1664.

3) Hondoh, H. et al. 2002. Biologia Cell. Mol. Biol.. in press.

\section{Ba-13 \\ 起源の異なる洀粉に対するネオプルラナーゼの作用について \\ （江崎グリコ・生化研） \\ O杉本和久、釜阪 寬、高田洋樹、西村隆久、栗木 隆、岡田茂孝}

【目的】演者らは先に Bacillus stearothermophilus 由来ネオプルラナーゼ"が澱粉を構成するアミロー スとアミロペクチンに対して異なる特異性を示すことを明らかにした ${ }^{2)}$ 。今回、種々の起源の澱粉に ネオプルラナーゼを作用させた際の各澱粉の变化および反応産物の特性について明らかにしたの で報告する。

【方法·結果】起源の異なる 6 種の澱粉にネオプルラナーゼを作用させ、反応生成物中のアミロース およびアミロペクチン含量変化をヨウ素比色法で測定した。またSEC-MALLS 法により反応生成物の 重量平均分子量の変化についても確認した。さらにウルチ種澱粉の代表として馬鈴薯澱粉、モチ種 澱粉の代表としてワキシーメイズ澱粉を基質としてネオプルラナーゼ処理を行った。ウルチ種の澱 粉においてはネオプルラナーゼの作用により澱粉中のアミロースが速やかに分解したがアミロペク チンは大きく分解されることなく残存した。一方、モ于種の澱粉ではネオプルラナ一ゼの作用により 若干の還元糖の増加がみられたが澱粉の大部分は未分解のまま残存していた。また全ての澱粉に おいてネオプルラナーゼの作用の進行にともない重量平均分子量は $10^{6} \sim 10^{7} \mathrm{kDa}$ に収束した。さら に冷蔵保存および冷凍解凍における澱粉の老化の進行を確認したところワキシーメイズ澱粉はネ オプルラナーゼによる作用の進行に伴い老化耐性が向上した。一方、馬鈴著澱粉は分解の初期段 階では未分解の澱粉よりも老化しやすい性質へと変化したが、さらに分解が進むと老化耐性が向上 した。ネオプルラナーゼを充分に作用させた馬鈴薯澱粉、ワキシーメイズ澱粉は 6 日間の冷蔵保存 あるいは冷凍·解凍を行ってもほとんど老化がおこらないことが確認された。

1) Kuriki, T. et al. 1996. J. Biol. Chem. 271: 17321.

2) Kamasaka, H. et al. 2002. Appl. Environ. Microbiol. 68: 1658. 
Ba-14 Klebsiella pneumoniae 由来プルラナーゼにおけるカルシウムイオンの役割

（福山大·生命工学・応生科）

○岩本博行、加茂靖史、尾上健、廣瀬順造

【目的】Klebsiella pneumoniae 由来プルラナーゼは、 $\alpha$-アミラーゼファミリーに属する分 子量約 12 万のデンプン枝切り酵素である。三上らによるX線結晶構造解析では、本酵素 1 分子 中にカルシウムあるいはマグネシウムと考えられる電子密度が5 個観察された" ${ }^{1}$ 。そこで本研 究では、まず酵素中に含まれるカルシウムイオンの数を定量し、次に 1 部のカルシウムイオン を抜き取った酵素を作製し、その熱安定性、至適温度などについて調べた。

【方法】実験には、(株)林原生物化学研究所社製の酵素を精製して用いた。カルシウムイオン の定量は、フレームレス形原子吸光分光光度計により測定した。酵素を $10 \mathrm{mM}$ EDTA を含む トリス塩酸緩衝液（pH 8.5）に対して透析することにより、カルシウムイオンの抜き取りを行 つた。酵素活性は、プルランを基質とし、還元力の増加を Park-Johnson 法により求めた。

【結果】原子吸光分析により、酵素 1 分子中に 5 つのカルシウムイオンが含まれることが分 かった。またEDTAに対して pH 8.5 で透析することにより、5つのカルシウムのうち約3つ が除去された。このカルシウム部分除去酵素は、Native 酵素に比べて至適温度、熱安定性とも に 5 10C低下した。次に、このカルシウム部分除去酵素に新たにカルシウムを加えると、熱 安定性、至適温度が Native 酵素と同程度まで回復した。

1) Mikami et al. (未発表)

\section{B 15 -アミラーゼとCGTaseから創成した2種類のキメラ醉素の性筫および權造との 関係（江崎グリコ・生化研、*日本大学·文理）}

O大段光司、"金子寛生、栗木 隆、岡田茂孝

【目的】 $\alpha$-アミラーゼの糖転移反応を利用して糖転移産物を得る際、糖供与体として生デンプンを用 いることは、転移効率およびエネルギ一効率の面から好ましいと考えられる。我々は、糖転移反応 を強力に触媒する $\alpha$-アミラーゼの C 末端領域にCGTase 由来生デンプン吸着ドメインを導入し、糖 転移活性を保持しつつ生デンプン吸着および分解活性を有するキメラ䤃素 2 種類を構築した1)。今 回、本キメラ䤃素の可溶性ならびに不溶性デンプンに対する作用特性の違いについて、䣼素の構造 面から考察を行つた。【方法·結果】生デンプン吸着能を有する Alkalophilic Bacillus sp. A2-5a 由来 CGTase ${ }^{2)}$ の各ドメインの境界位置を構造既知の CGTaseの詳細な構造情報をもとに決定した。 C 末 端欠失型 $\alpha$-アミラーゼ(Ba-S) の C 末端にA2-5a CGTase のEドメイン(生デンプン吸着ドメイン) ならびにD(機能未知)+Eドメインそれぞれを結合させたキメラ䣼素(Ch1 AmyならびにCh2 Amy)は、 Ba-S で観られなかった生デンプン吸着能および分解能を獲得し、それらはともにCh2 Amy の方が Ch1 Amy よりも高かった。また、可溶性デンプンを基質とした Ch2 Amy の触媒活性は Ch1 Amy およ び Ba-S の約 8 分の 1 であった。CGTase の立体構造と Ba-S の立体構造モデルから、Ch1 Amy お よびCh2 Amy の構造を予測した結果、Ch2 Amy では触媒ドメインから突き出たループと導入した ドメインとの間に立体障害が钼察され、これがCh2 Amy の触媒活性低下の原因であると予想された。 さらに、A2-5a CGTase の D+Eドメインが本来フレキシブルに立体的に配置され得る構造であること が、Ch2 Amy の生デンプンへの作用特性に影響していることが示唆されだ。

1) Ohdan, K. et al. 2000. Appl. Environ. Microbiol. 66: 3058-3064.

2) Ohdan, K. et al. 2000. Appl. Microbiol. Biotechnol. 53: 430-434.

3) Ohdan, K. and Kuriki, T 2002. Carbohydrate Bioengineering : Interdisciplinary Approaches pp. 99-105. 
ピーマンの成熟における $\beta$ ーガラクトシダーゼに関する研究 Bp-1

（東北大院・農・応生科）○小笠原諭、山形洋平、阿部敬悦、中島佑

【目的】ピーマン (Capsicum annuum) は成熟するにつれて緑色から赤色に変化し、そ れに伴って果実も軟化する。この硬さの変化は、糖質加水分解酵素による細胞壁多糖の 構造変化によるものと考えられる。果実成熟におけるグリコシダーゼ活性の変化を経時 的に調べたところ、ß-ガラクトシダーゼ活性だけが果実の成熟に伴い上昇することが明 らかになった。そこで、 $\beta$-ガラクトシダーゼの精製とクローニングを行い、ピーマンの 成熟における $\beta$-ガラクトシダーゼの機能を明らかにすることを本研究の目的とした。

【方法】緑色と赤色のピーマン果実からイオン交換、疎水、ゲルろ過のカラムクロマ トグラフィーより $\beta$-ガラクトシダーゼを精製した。トマト (Lycopeersicon essculentum) の 队-ガラクトシダーゼファミリーの遺伝子配列から PCR プライマーを設計し、ピーマン果 実由来 cDNA ライブラリーに対して PCR を行い増幅断片を得た。これをプローブとして ß-ガラクトシダーゼのクローニングを行った。ピーマンの各部位から total RNA 調製し、 先に得られた断片をプローブとしてノーザンブロットによる遺伝子発現の解析を行った。

【結果】精製より緑色では 4 種類、赤色では 3 種類の $\beta$-ガラクトシダーゼ活性を有す る画分を得た。このうち最も $\beta$-ガラクトシダーゼ活性の高かった赤色のピーマンの画分 $\mathrm{RB} 1$ の $\mathrm{N}$ 末端アミノ酸配列を決定した。この RB1の N 末端アミノ酸配列は、ピーマン 果実由来 cDNA ライブラリーよりクローニングした $\beta$-ガラクトシダーゼ PBG1 の推定ア ミノ酸配列の N末端側と一致した。またノーザンブロットによる PBG1 の遺伝子発現の 解析により、PBG1 は果実の成熟に特異的に発現していることが明らかとなった。

\section{$\mathrm{Bp}-2$ \\ 醉母Cryptococcus albidus の $\beta$-galactosidaseについて \\ (1（独）食総研、2筑波大学・応用生化) \\ ○北村義明1、真岩里江 ${ }^{1,2}$ 、松尾勝? 春見隆文 ${ }^{1}$}

【目的】高い糖転移活性を持つ $\beta$-galactosidaseの構造並びに糖転移機能の構造機能相関 を明らかにし、進化分子工学的手法等による糖轱移醉素の機能改良のための新しい醉素 分子素材を得ることを目的とし、土垷から分離したガラクトース転移活性の高い醉母 Cryptococcus albidus B-14a株の $\beta$-galactosidaseのCDNAクローニング並びに過剩発現 を行った。

【方法並びに結果】ガラクトース含有培地に生育させたC. albidus B-14a株のmRNAよ り、大腸菌/ac関連遺伝子を含まないプラズミドベクターpCorrectClone上にcDNAライ ブラリーを作成し、X-galの分解を指標にして $\beta$-galactosidaseのcDNAを選抜した。得 られた1455bpのORFを発現プラズミドpET23-dを用いて大腸菌内で過剩発現を行った ところ、培養 $1 \mathrm{ml}$ あたり約 66 U、粗抽出上清での比活性 $40.6 \mathrm{U} / \mathrm{mg}$ と、高いONP- $\beta-$ galactosidel分解活性の発現が得られた。塩基配列情報から推定された酵素タンパク質 のホモロジー検索では、他の $\beta$-galactosidase には相同性が高いものは検索されなかつ たが、Humicola grisea 並びにTrichoderma reesei 等の $\beta$-glucosidase と $40 \%$ 程度の相同 性が見いだされた。各種glucosideの分解活性を測定してみたところ、pNP- $\beta$ galactoside分解の約 2 倍程度のpNP- $\beta$-glucoside分解活性が検出された。 2 糖類の分解 性においても、cellobiose>>lactose > gentiobioseであり、本ORFは上記糸状菌の醉素と 同様に $\beta$-galactosidase 活性を有する $\beta$-glucosidaseであると考えられた。本醉母菌株中 には、糖転移活性の高い $\beta$-galactosidaseの他に、糖転移能が低く、aryl- $\beta$-galactoside 分解活性が高い分子種の存在が確認されているが、本ORFの発現タンパク質はこれと諸 性質が類似していた。 


\section{Bp-3 cyclodextrin の合成 \\ （横浜国際パイオ研, ")大阪市工研, ${ }^{2)}$ 食総研）○濱保健一, 伊藤哲也, 藤田孝輝, 原 耕三, 1) 北㚼寿美雄, ${ }^{21}$ 小林秀行}

【目的】グルコース以外の糖質を分岐側鎖として結合させたへテロ分岐サイクロデキストリ (CD)は，従来の CD に比較して溶血性や包接能が異なることが見出されてきた"．その中で も, Galactosyl-CD(Gal-CD) は, 従来の分岐 CD に比較して，溶血性が低く，その高い安全 性から医薬品などの付加価値の高い分野への用途が期待できる. 醭素反応によって CD 環 に直接 galactosyl 基を導入する方法としては, コーヒ一豆由来の $\alpha$-galactosidase の糖転移 反応がある.この場合は, 転移率が高い利点もあるが, コ一ヒ一豆からの酵素の生産性は低 く, 粗醭ではポリフェノール由来の着色のために精製が困難であり, 工業的生産には至って いない. 系状菌 M. vinacea は $\alpha$-galactosidase I 及び II の基質特異性の異なる 2 種類の 酵素を生産するが 2)，このうち $\alpha$-galactosidase II は糖受容体として CD を利用することがて きる. 本研究は本醭素の諸性質と糖転移反応を用いた Gal-CD の合成について報告する.

【方法と結果】糖供与体としてラフィノースまたは, ガラクトマンナン加水分解物を使用し， $\alpha$ ， $\beta C D$ を糖受容体に $M$. vinacea 由来の $\alpha$-galactosidase 剂を反応させ, 糖転移反応によっ て, Gal-CD の合成を行った. その結果, コーヒ一豆由来の $\alpha$-galactosidase と同様に主生成 物として, 6- $\alpha$-D-galactosyl-CD と, 副生成物として 2- $\alpha$-D-galactosyl-CD を生成した. さら に, 珪藻土に吸着させた $\alpha$-galactosidase 剂を用いて, キログラムスケールで Gal-CD を合 成した.

1) Chem. Pharm. Bull., 47, 1564, (1999)

2) Biosci. Biotech. Biochem., 63, 1096, (1999)

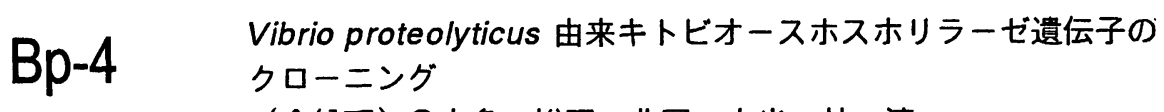

（食総研）○本多 裕司、北岡 本光、林 清

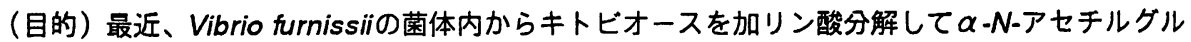

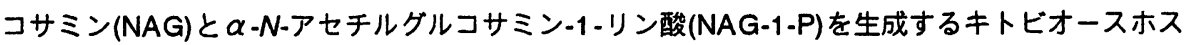
ホリラーゼ (ChBP)が発見された(1)。ChBPはアミノ酸配列上、セロビオースホスホリラーゼ

(CBP) と共に糖転移䣼素ファミリー36に分類されている。本研究では、Vibrio proteolyticus由 来ChBP遺伝子をクローニングして、大腸菌を用いた発現を試みた。

(方法および結果) CBPおよびChBPに保存されていたアミノ酸配列をもとにしてプライマーを設 計した。V. proteolyticus のゲノムを鋳型にして作成したプライマーを用いたPCR法によって、 $2.1 \mathrm{kbp}$ 增幅遺伝子断片を得た。得られた增幅断片の遺伝子配列を決定した後、さらにTAILPCR法を用いてChBPをコードする遉伝子の全堨基配列を決定した。得られたV. proteolyticus 由 来ChBPの推定アミノ酸配列を糖転移醇素ファミリー36に属する糖貿加リン酸分解醅素のアミノ 酸配列と比較すると、V. furnissii由来ChBPとは82\%、V. chorelaeのCBPと推定されている通伝 子と83\%の相同性を有していることが判った。大腸菌で発現させたChBPはSDS-PAGE上で単一 のバンドになるまで精製し、加リン酸分解反応と合成反応（逆反応）を調べた。本醅素はキトビ オースを加リン酸分解したが、セロビオースを加リン酸分解しなかった。また本䣼素はNAGと NAG-1-Pからキトビオースを生成したが、グルコースと $\alpha$-グルコース-1-リン酸に対して反忘性 がみられなかった。

(1) Park, J.K. et al. (2000) J.Biol. Chem. 275 pp.33077-33083 


\section{Bp-5 コージビオースホスホリラーゼによるヘテロオリゴ糖の調製とその機能 \\ (林原生化研) \\ ○山下 洋、西本友之、栢野真由美、久保田倫夫、福田恵温、栗本雅司、辻阪好夫}

【目的】コージビオースホスホリラ一ゼ(KPase)を用いて $\alpha-1,2$ 結合を含むへテロオリゴ糖を調製し、そ の物性や機能性を調査すること。

【方法】Thermoanaerobacter brockii ATCC35047 由来 KPase の組換え体を大腸菌に発現させ、酔素剂 とした。ßーグルコース 1ーリン酸( $($-G1P)をグルコシル供与体とし、D-キシロース、マルトース、スク ロースをそれぞれグルコシル受容体として $\mathrm{pH} 5.5,60^{\circ} \mathrm{C}$ でKPaseを作用させた。反応液を脱塩、カラム分 画して目的のオリゴ糖を調製した。これらについて各種物性·生理的機能性を試験した。

【結果】受容体D-キシロース、マルトース、スクロースへの転移生成物のうち Glc $\alpha 1 \rightarrow 2 X y l(G X), G l c \alpha 1$ $\rightarrow 2 \mathrm{Glc} \alpha 1 \rightarrow 4 \mathrm{Glc}(\mathrm{KG}), \mathrm{Glc} \alpha 1 \rightarrow 2 \mathrm{Glc} \alpha 1 \rightarrow \beta 2 \mathrm{Fru}(\mathrm{KF})$ をそれぞれ目的オリゴ糖とし、オリゴ糖生成反応に おける KPase 作用量および $\beta$-G1P 濃度、 $\beta$-G1P 対受容体比率を最適化した。93.1g の原料( $\beta$-G1P と受 容体)から 16.0gの GX(純度 99.5\%)を、同様に原料 77.3g から 16.1gの KG(純度 97.9\%)、13.1gの KF(純度 97.7\%)をそれぞれ調製した。反応液中に残存する未反応の受容体は、スクロースとマルトースについて は酵母処理により、D-キシロースについては活性炭力ラムによりそれぞれ効率よく除去できた。GX, KG は還元力が低かったが、ポリペプトンに対する GX のメイラ一ド反応性は高かった。KF は非還元性でメ イラード反応性も示さなかった。KF は酸性側、GX はアルカリ性側で不安定であったのに対し、KG は幅 広い pH 域で安定であった。KG とKF はグリコシダーゼや小腸粘膜酵素による分解をほとんど受けず、 難消化性糖であることがわかった。いずれのオリゴ糖も、う蝕原性細菌による酸醗醭を受けなかった。 腸内細菌資化性についても報告する予定である。

(本研究は生研機構「新事業創出研究開発事業」による)

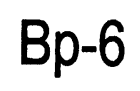

ランダム変異による新機能性コージビオースホスホリラーゼ

（林原生化研）○山本拓生、向井和久、仲田哲也、久保田倫夫、

福田恵温、栗本雅司、辻阪好夫

【目的】コージビオースホスホリラーゼ (KPase) はコージビオースの $\alpha-1,2$ 結合を加リン酸分解 する。また、可逆的に $\alpha-1,2$ 結合を生成しコージビオースやオリコ糖をつくる醰素である。本研究 では、KPase 遺伝子にランダム変異を導入して、新しい機能性を獲得した変異 KPase 䤉素を取得し、 有用糖質生産に活用することを目的とした。

【方法】Thermoanaerobacter brocki i ATCC35047 株由来のKPase 遺伝子を用い、ランダム変異を行 った。変異導入した遺伝子をプラスミドベクターpKK223-3に連結後、大腸菌 JM109に形質転換し

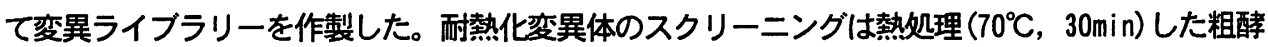
素液の残存活性を指標として行った。粗酵素夜にグルコースと $\beta$-グルコース 1-リン酸（ $\beta-G 1 P ）$ とを作用させ、生成物を TLC 分析して特異性変異体をスクリーニングした。

【結果】1330 株をスクリーニングした結果、而熱化変異体が 1 株、反応生成物の TLC パターンか野

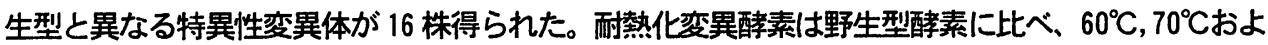
び 75Cにおける活性半減期がそれぞれ 1.6 倍, 7 倍, 6 倍に長くなっていた。DNA 配列を決定したと ころ、本変異酵素はAsp513Asn 変異体であることがわかった。この変異酔素を精製して比活性を測 定したところ、64.1U/mg であり、野生型䤏素のそれと比べて約 90\%の值であった。特異性变異体の いずれもか野生型酵素に比べ、DP5〜7 の生成比の増加が顕著であった。これら変異醉素のうち 2つ について置換アミノ酸を特定したところ、それらはSer676Asn 变異体、Asn6871/ e 変異体であった。 (本研究は、生研機構「新事業創出研究開発事業」による) 
セロビオースホスホリラーゼによるグルカールへの付加反応は

可逆である

(1 食総研、2 東理大院・生物工)

○野村 圭 1,2 、北岡 本光 1 、山登 一郎 2、吉田 充輝 2、林 清 1

【目的】Cellvibrio gilvus 由来セロビオースホスホリラーゼ(CBP)の基質としてグルカール を用いることにより二糖合成反応、リン酸付加反応が触媒され、2'・゙オキシ・セロビオース

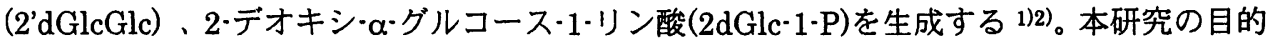
は、これらの生成物に対する CBP の反応特性を明らかにすることである。

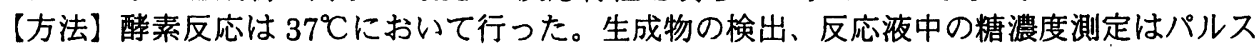
ドアンペロメトリー検出器を装備したイオンクロマトグラフィー装置を用いて行った。

【結果】2'dGlcGlc とリン酸を基質として CBP による加リン酸分解反応について検討を行 ったところ、予想された生成物である $2 \mathrm{dGlc}-1 \cdot \mathrm{P}$ とグルコース以外に、グルカールの生成 が確認された。グルカールを基質とした二糖合成反応の可逆性について検討を行ったとこ ろ、CBP は 2'dGlcGlc をグルカールとグルコースに分解する脱離反応を触媒することが明 らかとなった。また、この反応は二糖合成反応を加速する働きを持つリン酸を添加するこ とによって加速した。

一方、リン酸付加反応の生成物である $2 \mathrm{dGlc}-1 \cdot \mathrm{P}$ を CBP の基質として用いたときにも同 様にグルカールの生成が確認された。また、リン酸付加反応の加速因子であるグルコース の添加によって反応速度が増加した。

本研究の結果は、非天然型糖質であるグルカールの醳素的生成を初めて示すものである。 1)野村 圭ら：日本応用糖質科学会 2000 年度大会講演要旨集 $p .64$

2)野村 圭ら：日本応用糖質科学会 2001 年度大会講演要旨集 p.54

\section{Bp-8 \\ Synthesis of Cellobiose Coated PAMAM Dendrimers: As Substrate for the Enzyme Cellodextrin Phosphorylase (National Food Research Institute) OAmbar K. Choudhury, Motomitsu Kitaoka and Kiyoshi Hayashi}

Phosphorylase mediated enzymatic synthesis in carbohydrates is well documented. Cellodextrin phosphorylase (CDP), a phosphorylase group of enzyme has found very effective for the synthesis of cello-oligosaccharides and required cellobiose as a smallest substrate for the elongation of sugar chain. Polyamidoamine (PAMAM) dendrimers of generations $0,1,2,3,4$ are highly branched macromolecules having $4,8,16,32,64$ amino groups on its surface respectively. To elaborate the effectiveness of the enzyme cellodextrin phosphorylase towards multivalent cellobiose coated glycoconjugates, chemically synthesized cellobiose dimmers, cellobiose trimers, as well as cellobiose coated PAMAM dendrimers of generations $0,1,2,3$ and 4 having 4, 8, 16, 32 and 64 cellobiose unit at the outer surface of the PAMAM dendrimers respectively, have been used as substrate. It was found that compounds upto 16 cellobiose units were good substrate for the enzyme CDP. The substrate specificities were determined by measuring OD at $700 \mathrm{~nm}$ followed by determination of the rate of phosphate transfer $(\mu \mathrm{mol} / \mathrm{min})$. However, for compounds having 32 and 64 cellobiose units, substrate specificities could not be determined due to the precipitation before the measurement of OD at $700 \mathrm{~nm}$. 


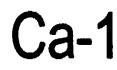

示差走查熱測定によるグルカンの水和水量の測定 （阪府大院·農生科）

○鈴木志保、深田はるみ、小川宏藏、北村進一

【目的】アミロースとカードランについて、水分含量の異なる条件下で示差走查熱測定 (D SC)を行い、それらのグルカンの水和水量を測定した。

【方法】酳素合成アミロース(平均分子量 820,000)およびカードランをDSC装置のサンプ ルセルに入れ、異なる量比で水を加え、 $120^{\circ} \mathrm{C}$ ま昇温した後、 $-45^{\circ} \mathrm{C}$ ま冷却した。これ を $0.5 \mathrm{~K} / \mathrm{min}$ で $20^{\circ} \mathrm{C}$ まで昇温し、凍結水の融解に伴う融解熱を測定した。測定値から凍 結水の融解熱が 0 になる時の相対水分量を求め、水和水量とした。

【結果】多糖-水系の凍結水の融解に伴う吸熱ピークは、水分量の減少に伴い低温側へ シフトし、相対水分量 $0.43\left(\mathrm{~g}\right.$ 水 $/ \mathrm{g}$ 多糖の絶乾重量)のアミロースでは、 $-5.9^{\circ} \mathrm{C}$ 、相対水分 量 0.39 のカードランでは-22.9 ${ }^{\circ} \mathrm{C}$ あった。アアミロースおよびカードランの水和水贯はそれ ぞれ $0.40 、 0.31$ であり、グルコース 1 残基当たりでは $3.65 、 2.79$ の水和水分子が存在し ていることがわかった。カードランの水和水量が少ないのは、カードラン分子鎮の一部が 三重らせんで存在しており、多糖の水酸基が相互作用するためと考えられる。

\section{Ca-2 \\ 逆相カートリッジを用いたでん粉の鎖長分布の簡便測定法

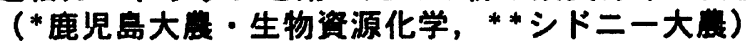 \\ O北原兼文*・菅沼俊彦* - Les Copeland**}

【目的】枝切りでん粉のゲルろ過分析は，見かけのアミロース含量やアミロペク チンの単位鎖欈成などの重要な構造情報を与えるが, オープンカラムによる分析 は長い時間と煩雑な検出を要し, 液ク口による分析は高価な機器を要する。ここ では，逆相カートリッジを用いて简便な鎖長分布測定法を開発したので報告する。

【方法】逆相カートリッジはSep-Pak C18 カートリッジを用いた。アミロース (AM) またはアミロペクチン (AP) ，直鎖グルカン，イソアミラーゼによる枝切 りでん粉溶液をカートリッジに通し，溶出液の全轄量はフェノール硫酸法により 測定した。また，枝切りでん粉と溶出画分のゲルろ過には SephadexG75 を用いた。 【結果】AMとAPはC18 カートリッジに吸着され，メタノール水溶液を通すこと によりー部が回収された。最も効果的な溶出溶媒は $10 \%$ れタールであった。グ ルコースやマルトースはほとんど吸着されなかったが, 直䍻アミロースは完全に 吸着され, 10\%メタノール溶液による回収量は重合度が大きくなるにつれ減少した。 このように直鎖グルカンの吸着性には重合度依存性が認められた。枝切りデンプ ンとカートリッジ画分のゲルろ過分析により，技切りデンプンの負荷と $3 \%$ タノ 一ル溶出画分はA鎖とB 1 鎖を主体とするアミロペクチンの短鎖単位䍻画分に対 応すること，8\%メタノール浴出画分はB 2 鎖以上のアミロペクチン長鎮単位镍画 分に対応すること，10\%メタノール浴出画分は一部のアミロース成分に対応し，こ の画分と回収不可能な吸著画分の合計は見かけのアミロース含量に対応すること が分かった。これらの検証を 13 種のテンプンで行い, 本研究での C18 カートリッ ジ分画法の結果は, 従来のゲルろ過分析法のものと䭪めて良好な相関を示した。 


\section{C 蛍光標識法によるアミロペクチン分子の分岐構造の解析 \\ （鹿児島大・農・生資化） \\ ○田川正高 ${ }^{1)}$ 、花城 勲、竹田靖史}

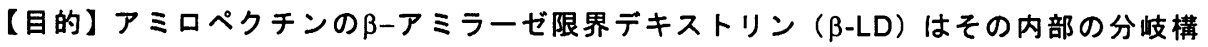
造を保持している。その構造解析により、アミロペクチン分子の解析からは得られない 分岐構造に関する情報が得られる。本研究では $\beta-L D の$ 単位鎖の分布を蛍光標識法により 調ヘ、枝の数について考慮した分岐構造モデルの構築を試みた。

【方法】コムギ、コメ、トウモロコシ、ジャガイモ、サッマイモ、ナガイモのアミロペ クチンの $\beta$-LD を調製し、その単位鎖とC 鎖の数分布を測定した。 $\beta$-LD の単位鎖は、 イソアミラーゼ、プルラナーゼにより順次枝切りして調製した。蛍光標識とゲルろ過 HPLCによる分析は既報 ${ }^{2)} に$ 準じて行なった。

【結果】 $\beta$-LD 単位鎖のモル比 $(A+B 1) /(B 2+B 3)$ の值から求めた、1つのクラスターを構 成するA および B1 鎖の数は、A 型の結晶型を示す澱粉で 7.8 12.2、B 型の澱粉で 3.6 〜6.0であった。B1 鎖 1 本に結合する $A$ 鎖の数は、A 型の澱粉で 1.4 2.0、B 型の澱粉 で 2.1〜2.3となり、アミロペクチン単位鎖を分析して得られた結果とは若干異なった。 また、C 鎖上の分岐結合は、非還元末端基側から 10 残基付近、還元末端基側からは短 いもので 4〜 5 残基の部位に多いことが示唆された。これらの結果をもとに、アミロペ クチン分子の分岐構造およびC 鎖近傍の構造モデルを提案する。

1) 現 日本澱粉工業株式会社 2 ) Hanashiro et al., Carbohydr. Res., (2002) in press.

\section{Ca-4 物牲が異なるモチ米の澱粉構造研究 \\ (三重大·生資、*北海道立中央農試) \\ ○渡辺雅子、陳 潔梅、*中森朋子、三島 隆、久松 眞}

目的 はくちょうもち(北海道産)のモチ生地はヒヨクモチ(佐賀県産)と比べ柔らかい。この物性 の違いはアミロペクチン分子を構成している短鎖アミロースの鎖長特性に起因していると推察し 両澱粉の鎖長分布を比較した。

方法 脱タンパク、脱脂処理した澱粉 $30 \mathrm{mg}$ をアルカリで糊化後中和し $50 \mathrm{mM}$ 酶酸爱衝夜(pH3.5)

を加えて $30 \mathrm{ml}$ とし、イソアミラーゼで完全枝切り処理(150mU、3 時間)と約 15\%程度の部分枝 切り処理 (15mU、2-3 時間) を行った。加熱失活後両試料をトヨパール HW50S にかけ、分子量 の大きさから f1、f2、f3 の画分に分けた。アミロペクチン分子の外層部の短鎖アミロースである $A$ 鎖やB1 鎖が溶出する部分枝切り試料の $\mathrm{f} 3$ 区分はタイオネクスて鎖長分布を分析した。

結果 モチ澱粉であるため完全枝切りした試料の $\mathrm{f} 1$ 区分はほとんど溶出されなかった。また、こ の試料の $\mathrm{f} 2 、 \mathrm{f3}$ 画分の比はいずれも類似していた。一方、約 15\%枝切り反応試料からアミロペク チン分子の外側を構成している鎖長特性を比較した。その結果、はくちょうもちはヒヨクモチと 比べ重合度 11 以下の鎖長が多く分布していることが分かった。これらの結果から推察すると、短 鎖乃ミロースが比較的多いはくちょうもちは、モチ生地にした時の澱粉分子間のネットワークが ヒヨクモチより構築しにくいため、柔らかい生地となることが推察された。 


\section{Ca-5 マングローブ胚軸の成熟と実生への過程における \\ 溊粉の構造と性質の変化 \\ （鹿児島大・農・生資化、“琉球大・熱生研）

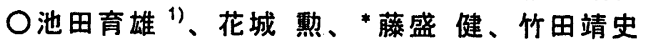

【目的】昨年度の本大会においてヒルギ科のマングローブ 3 種類について、完熟した胚 軸の澱粉の分子構造と性質について報告した。本研究では、メヒルギについて、胚軸の 成熟と実生への過程における澱粉の分子構造と性質の变化を調べ、胚軸澱粉の合成と消 失について考察した。

【方法】胚軸重量が $2 \mathrm{~g}$ 以下のものを未熟、9 11 g のものを完熟、また、発芽、発根し たもの（8 12 g) を実生とし、水曲出法で澱粉を調製した。ブタノール法の改良法によ ってアミロース (AM) とアミロペクチン (AP) を分別調製し、それらの分子構造を営 光標識法 ${ }^{2,3}$ その他の手法により解析した。

【結果】未熟から完熟、実生への過程で、それぞれ澱粉含量 (\%)が 23.9、28.9、25.1、 溊粉の平均粒径 $(\mu \mathrm{m})$ は 9、19、18、最高粘度 (RVU) は 63、334、377で、成熟の過 程で大きく増加した。AM 含量（\%）は26.2、24.5、21.8に変化した。AM、AP の基本 構造には大きな変化は認められなかったが、いずれも数平均重合度は增加した。従って、 マングローブ胚軸澱粉の合成は、まず AM 含量の高い小粒ができ、その後 AP の合成が 盛んになり、粒の成長に従いAM 含量の低い大粒に合成されると推測した。一方、実生 の皮層部にアミラーゼ活性が強く認められたことから、分解に際しては皮層部のAM 含 量が高く重合度の小さいAM、APからなる粒が優先的に分解されると推測した。

1) 現 熊本製粉株式会社 2) I. Hanashiro and Y. Takeda, Carbohydr. Res., 306 (1998) 421-426. 3 ) I. Hanashiro et al., Carbohydr. Res., (2002) in press.

\section{Ca-6 \\ Physicochemical properties and molecular structures of starches \\ from millet and sorghum species in Nigeria \\ (Dept. Biochem. Sci. Technol., Fac. Agric., Kagoshima Univ.) \\ OTerna Gaffa, Yashushi Yoshimoto, Isao Hanashiro, Yasuhito Takeda}

Some physicochemical properties and molecular structures of starches from millet ('doro' and 'gero') and sorghum (Sorghum bicolor and S. vulgare) species in Nigeria were examined. The starches were isolated from the grains by an alkaline steeping method. The starch was defatted by repeated dissolution in hot dimethyl sulfoxide solution and precipitated with ethanol, then fractionated into amylose and amylopectin. The actual amylose content (\%) based on iodine affinity (IA) determination ranged from 20.1-21.4 for sorghum and 21.3 for millet. The amylose IA (g/100g) for 'doro' was 18.6 and 'gero' 19.1 while 19.3 and 20.3 were obtained for $S$. bicolor and $S$. vulgare respectively. The amylopectin IA $(\mathrm{g} / 100 \mathrm{~g})$ were 1.27-1.29 for sorghum and 1.37-1.42 for millet with blue values of 0.18 and 0.19 respectively. The $\lambda \max$ was from $569-574 \mathrm{~nm}$ and chain lengths were $20-21$ with $\beta$-amylolysis limits of $56 \%$. Pasting properties differed with the samples except for millet species that had almost same peak viscosities (204 and 206 RVU), and also minimum viscosities for sorghum species showed nearly same (152 and 153 RVU) values. The thermal behavior of the starches on differential scanning calorimetry (DSC) showed gelatinization temperature $\left({ }^{\circ} \mathrm{C}\right.$ ) range of 66-67 for millet and 67-69 for sorghum with enthalpy change of $13.3-14.7 \mathrm{~J} / \mathrm{g}$. The X-ray diffraction pattern displayed by the starches was the A-type crystallinity common with cereals. Examination of other molecular structures is in progress. 


\section{酒米の澱粉搆造特性について \\ Ca-7 (三重大・生資、*愛知県食品工業技術センター) \\ O陳 潔梅、*西田淑男、TitiC.Sunarti、三島 隆、久松 畺}

目的 清酒用米澱粉の特長、特にアミロペクチンの構造に関する知見はほとんどない。我々はア ミロースとアミロペクチンを分別せずにアミロペクチン分子の鎖長分布情報を得る手法を開発し てきたので、酒米の特性の一端を明らかにする目的で、この簡便去を適用し炊飯米と比較した。

方法 酒米としては山田錦、五百万石、美山錦、北錦、若水を、比較する米としてコシヒカリ、 日本晴、キララ 397 を使用した。脱タンパク・脱脂処理した澱粉 $30 \mathrm{mg}$ を溶解 $(30 \mathrm{ml})$ し、イソ アミラーゼで完全枝切りした試料(CH) と約 15\%程度枝切りした試料(PH)を調製した。いずれもト ヨパール HW50S にかけ分子量順に f1、f2、f3 の 3 画分に分けた。 CH の f1 からアミロース含量 を推定し、PH の $\mathrm{f} 3$ 区分はタイイオネクスで分析しアミロペクチン分子の外部を構成している鎖長 特性を調べた。一方、澱粉の糊化特性はRVAで分析した。

結果 調へた米澱粉いずれもアミロース含量は 14-17\%で極端な違いはなかった。PH の f3 区分 に集められた短鎖アミロースの鎖長分布をコシヒカリと比較すると、いずれの酒米も重合度 10-11 以下の短鎖アミロースが少なく、それ以上の短鎖アミロースが多かった。この結果、酒米のアミ ロペクチンは外部鎖長が長めの短鎖アミロースで構成されている米と判断でき、酒米は老化しや すい米と推察した。RVA で則定した最大粘度とセットバックの值でも酒米の特長が得られた。若 水と日本睛は酒米の特長を一部有していることも分かった。

\section{Ca-8 西表島産イモ類の澱粉の構造と性質 \\ ○徐萌、小西洋太郎、米盛重友*、藤盛健*、井ノ内直良**（大 阪市大院・生活科学、*琉球大・熱帯生物圏研究センター、** 福山大・工）}

【目的】未利用・低利用資源植物の開発の一環として、西表島に自生する数種の イモ類から澱粉粒を調製し、その構造と性質について調べた。

【方法】分析したイモは、キールンヤマノイモ2 種（やまのいも科）、ニガカシュ ウ (同)、クワズイモ（さといも科）、タイモ（同）、アロールート（くずうこん科） ササバサンキライ (ゆり科) である。このうちタイモのみ食用とされている。澱 粉粒は Schoch らの方法に準じて調製した。

【結果】調製した澱粉はすべてウルチ性であった。試料のうち、キールンヤマノ イモ澱粉は、ジャガイモ澱粉と同様に、アミロース含量は約 $22 \%$ 、X線回折図は B 型を示し、ダビアーゼによる分解性も低かった。しかし、以下の点で特徵的で あった。(1) HPAEC-PAD によるアミロペクチンの短鎖(DP = 6〜12)の割合が分 析試料の中で最も少なく、10\%前後であった。（2）糊化開始温度、糊化ピーク温

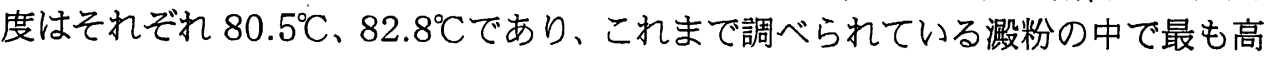
い值を示した。 


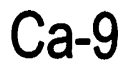

ソ八㮔子澱粉の分子構造と糊化特性

（鹿児島大・農・生資化，“長野県食工試，"*霧島酒造侏）

○吉元 窑，江頭玲美，花城 勲， ${ }^{*}$ 大日方 洋， **高瀬良和，竹田靖史

【目的】ソバは雑穀の一つで，国内では古くから食用として栽培されている. 主成分は約 $70 \%$ を占める澱粉で， これまでその物理化学的性質は調べられているが，分子構造は詳細に調へられていない，本研究では，できる だけ多くのソハ品種について，澱粉をアミロースとアミロペクチンに分別し，その分子構造と澱粉の糊化特性 を調べた.

【方法】試料として普通ソパ7品種とダッタンソバ 1 品種を用いた. 澱粉はアルカリ浸漬法により調製し，ア ミロースとアミロペクチンはブタノール法の改良法により分別調製した．澱粉の糊化特性はラピッドビスコア ナライザーで調べ，分子構造の分析は既報りに準じて行ない，分子量分布は巣光ラベル法で測定した.

【結果】糊化特性では，糊化開始温度は品種間で約 $70^{\circ} \mathrm{C}$ ほほほ同しであったが，ブレ一クダウン (37-98RVU) やセットバック (180-226 RVU) に相違か認められた. 大麦やトウモロコシ澱粉と比較して、ソ八澱粉は $40^{\circ} \mathrm{C}$ における粘度とセットバックが高く，ゲル化しやすい性質を持つことが示唆された．澱粉粒の結晶型はいずれ も A 型であった. 真のアミロース含量は 15.6-17.9\%，アミロペクチンのヨウ素親和力を考慮せずに求めた見か けのアミロース含量は 25.5-26.5\%で, 真と見かけのアミロース含量の差が 8.6-10.5\%と大きいことがわかった. アミロースのヨウ素親和力 $(\mathrm{g} / 100 \mathrm{~g})$ は 19.3-20.2 で, アミロペクチンでは2.21-2.48 と高かった. アミロペク チンの鎖長分布では，いずれも超長鎖画分が重量で約 10\%と特に多いことを認めた．また，短鎖画分 (B1+A 鎖) は数分布，重量分布ともに2 つの明膫なピークを示し，小麦と類似していたが，1つのピークを示すトウ モロコシやジャガイモとは異なっていた．その他，アミロースの分子量分布などについても報告する.

1)竹田靖史 : 澱粉科学, 40，61-71（1993）。

\section{Ca-10}

\section{アマランスA.cruentusとA.caudatus 澱粉の性啠}

(福山大・生命工'、信州大・農”、大阪市大院 ${ }^{3}$ ) ○井/内直良'

根本和洋 ${ }^{2}$ 、田口恭平 ${ }^{1}$ 、前田祐里 ${ }^{\prime}$ 、小西洋太郎 ${ }^{3}$ 、不破英次

【目的】アマランスはヒユ科の植物であり、主な栽培種はAmaranthus cruentus ( $A$. cruentus), A.hypochondriacus, A.caudatus の三種である。今回、世界各地で栽培さ れているA.cruentusとA.caudatus の種子中の潵粉の性澌を調べた。

【方法】世界各地（アメリカ合衆国、メキシコ、グアテマラ、ボリビア、ネパール、ア ルゼンチン、ペルー) で栽培されているA.cruentusとA.caudatus の種子を2000年秋 に信州大学農学部農場で栽培したアマランスの種子から泠アルカリ浸漬法により試料殿 粉を調製した。種子切片のヨウ素染色性の観察、および澱粉のヨウ素吸収曲線、GPCカ ラムによる枝切りした淑粉のアミロース含量とアミロペクチンの側鎖長分布、HPAECPAD法によるアミロペクチンの短鎖領域の側鎖長分布、殸粉のMicro DSC IIIIよる糊化 ·老化特性などの測定は常法により行った。

【結果】種子切片のヨウ素染色性、ヨウ素吸収曲線、GPCカラムの溶出曲線のいずれの 結果からも、A.cruentusとA.caudatus のそれぞれの種子中の㨽粉にはモチ性、低アミ ロース性、ウルチ性のものが存在していた。今までにA.caudatus にモチ性の報告がな く、今回はじめてA.caudatusにモチ性激粉が見い出された。アマランス澉粉のアミロ ペクチン側鎖は通常の植物激粉に比べて短いが、A.caudatusのアミロペクチン側鎖は A.cruentusよりさらに有意に短く、㳶粉の糊化温度が低い傾向がみられた。 


\section{Ca-11}

インディカ米およびその関連品種の米胚乳洀粉の性得

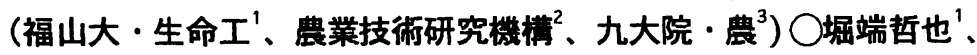

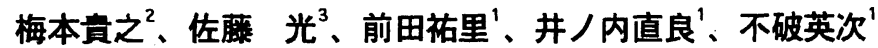

【目的】アミロースを合成するWx遗伝子産物(結合型激粉合成醉素；GBSSI)、もしくは Alk (アルカリ崩壊性) 候補遺伝子産物(激粉合成醉素 lla : SSlla ) がアミロペクチンの非 常に長い側鎖(SLC)の生成に関与している可能性を検討するために、SLCをもつインデ ィカ米およびその関連品種の米胚乳溜粉の性䓄を調べた。

【方法】試料米としてIR36(インディカ米)、EM1 109(IR36の糯変異体米)、Kasalath (インディカ米)、SL-23(日本晴遺伝子型背景でWx座、Alk座を含む第 6 染色体の約 3 分の 2 がKasalath遺伝子型に置き換わった系統)の精白米から冷アルカリ浸清法により

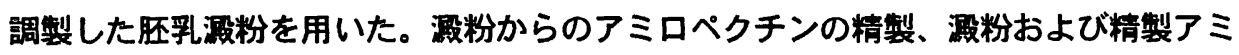
ロペクチンのヨウ素吸収曲線、酔素・クロマト法による溶出曲線、HPAEC-PAD法に よるアミロペクチンの短鎖領域の側鎖長分布、肧乳娍粉のMicro DSCIII による糊化と 老化特性、胚乳敏粉のRVAによる粘度特性などの測定は常法により行った。

【結果】IR36の精製アミロペクチン中にはSLCが約11\%存在しており、EM1 109には SLCの存在は認められなかった。従って、Wx座の逼い、すなわちGBSSがSLCの有無 に関与している可能性が考えられた。アルカリ崩壊性が難であるKasalath、SL-23と もにアミロペクチンにSLCが存在していたので、Alk座の逜いがSLCの存在に何らかの 影響を及ぼしている可能性についてもさらに検討が必要である。

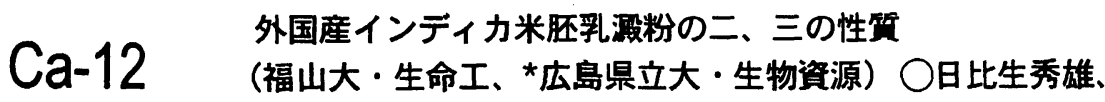

*猪谷富雄、堀端哲也、前田鿆里、井ノ内直良、不破英次

【目的】我々は農水省の新形筑米プロジェクト(現在、21世紀プロジェクト)の一環と して日本で品種化されたホシユタカなどのインディカ米の肧乳洀粉の性筫を調へてき

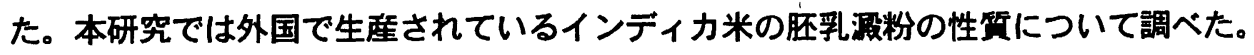

【方法】試料として、外国で生産されているDella (米国)、Labell (米国)、IR28(フィリ ピン)、Basmati370 (パキスタン)、Surjamkhi(インド)の 5 種のインディカ米を2000 年に厷岛県立大水田で栽培し、その精白米から泠アルカリ浸漬法により調製した肧乳晸 粉を用いた。濑粉からのアミロペクチンの精製、泚粉および精製アミロペクチンのヨウ 秦吸収曲楾、醥・素・ロマト法による溶出曲線、HPAEC-PAD法によるアミロペクチン の短鎖領域の側鎖長分布、䀝潤力·溶解度曲線などの測定を行い、肧乳酒粉及び精白米 のmicroDSC IIIIよる秙化·老化特性、RVAによる肧乳晸粉の粘度特性を調へた。

【結果】いずれのインティカ米肧乳洒粉の見掛けのアミロース含量も、通常のジャポニ カ米よりも高く、特にIR28とSurjamkhiは高い值を示した。IR28とSurjamkhiのアミロ ペクチンには非常に長い側鎖が存在しており、高いRVAのsetback值を示した。試料米 の中で、アミロペクチンの短い側鎖(DP6〜12)の割合が最も高いのはIR28であり、そ のIR28の晸粉粒は最も低い糊化温度を示した。 


\section{新形䓄米の精白米および肧乳滑粉の糊化・老化特性 （福山大・生命工）○中元詖亮、武元麻友美、前田祐里、 井ノ内直良、不破英次}

【目的】農林水産省がスーパーライス計画で育成した多数の新形得米の中で、アミロー ス含量とアミロペクチンの側鎖長分布に特徽のある精白米および胚乳源粉の糊化・老化 特性を明らかにすることを目的とした。

【方法】実験試料として、1999年に各地農業研究センターで栽培された新形犋米（ス ノーパール、ミルキークイーン、アケノホシ、ホシユタカ、夢十色）および比較粳米

（コシヒカリ）、比較糯米（ヒヨクモチ）のそれそれれの精白米、精白米粉末、および精

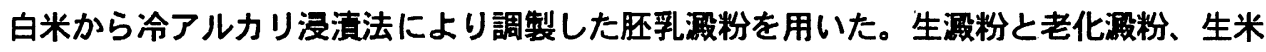
と老化米のMicro.DSC IIIIよる糊化特性、Micro DSC IIII試料容器内で $5^{\circ}$ Cで7日间老化 させた米 (老化米) のX線回折図形、およびBAP法による老化度の測定を行った。

【結果】老化米のBAP法による老化度はヒヨクモチ(21\%)、スノーパール(34\%)、ミル

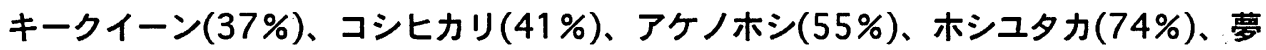
十色(77\%)であった。これらの結果と、老化米のX線回折図形の結果、および既に報告 したRVAのセットバック值、真のアミロース含量、アミロペクチンの非常に長い側鎖含 量と短鎖領域の側鎖長分布などの結果" 2) との間には密接な関係が存在していた。 1) 中元ら 農化講演要旨集, p.32 (2001)，2) 内海ら 農化講演要旨集, p.32 (2001)

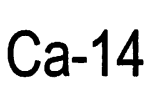

近交系トウモロコシ Oh43のamylose-extender(ae)遺伝子を含む 二重、三重変異体の胚乳洀粉の構造と物理化学的特性 （福山大·生命工、*Purdue Univ.)

○内海好規、“David V. Glover、井ノ内直良、不破英次

【目的】 amylose-extender遗伝子(ae)をもつトウモロコシ胚乳激粉は難消化性娍粉、 フイルムなどの原料晸粉として幅広い利用適性をもっている。本実験ではaeの他に、 dull (du)、sugary2(su2)などの少性道伝子をもつ二重、三重変異体トウモロコシ潵粉 の構造とその物理化学的特性を調へた。

【方法】Purdue大学農学部農場で栽培されたトウモロコシ穀粒からSchochの方法によ り肧乳溜粉を調製し、激粉の分子量分布をTSK gel Toyopearl HW75S - HW65S HW55S連結カラムで、イソアミラーゼで枝切りした側鎖長分布をTSK gel Toyopearl HW55S - HW 50S連結カラムで測定した。またHPAEC-PAD法によるアミロペクチン の短鎖領域の側鎖長分布、生㴲粉および老化晸粉のmicro DSC IIIKよる糊化特性、粗 グルコアミラーゼを用いた澱粉粒の分解率、X線回折図の測定を行った。

【結果】ae䄍粉はnormal 激粉に比べ、アミロース含量、糊化温度が高く、醇素によ る分解率が低い傾向がみられた。ただしae遺伝子を含む二重、三重変異体源粉の場合、 $a e$ 以外の遺伝子の影響により、湢粉の分子量分布、側鎖長分布、糊化温度、糊化熱、 酥素による分解率、結晶図形などが多様に異なっていた。 


\section{Ca-15 突然変異米の酵素変異と理化学特性 \\ (独法食総研、*九大遗伝子資源七多-) \\ ○大坪研一、岡留博司、中村澄子、 $*$ 佐藤 光、*熊丸敏博}

【目的】本研究の目的は、米デンプンの生合成機構の解明を図り、米の特性を広げて新 用途適性を付与することである。特に、本発表では、デンプン合成関連酵素の品質特性 への影響を解明することを目的とした。

【方法】インディカ（IR36）、ジャポニカ（金南風、台中 65 号）及びそれらの化学的突 然変異系統を試料とした。糊化特性は RVA 法、米飯物性はテンシプレッサーによるー 粒法によって米飯表層部及び粒全体の硬さ、粘り、バランス度等を測定した。米から CTAB 法により DNA を抽出し、各種プライマー存在下で PCR を行い、電気泳動によって増幅 DNA を検出した。

【結果】GBSS の欠損または減少によるモチ及び低アミロース系統は、米飯が軟らかく、 粘りが強かった。枝付け酵素 I の欠損では米飯表層がやや硬くなり、粒全体の粘りが増 加したが、GBSS 欠損が重なると、対照より軟らかくなった。枝付け酵素 II b の欠損に よる $a e$ 系統では、糊化 BD が小さく、最終粘度が高かった。米飯の粘りが著しく減少し: 硬くなったが、GBSS 減少によりこれらの変化は抑制された。イソアミラーゼ欠損のシ ユガリー系統においては、糊化粘度が著しく低く、米飯の粘りが減少した。枝付け酵素 II 欠損の共存により、米飯粘りの減少は強調された。台中 65 号の心白・フォスフォリラ 一ゼ欠損系統は対照に比べて軟らかく、粘りが強くなったが、その傾向は、米飯表層部 でさらに顕著であった。インディカのモチ系統は対照のIR36より軟らかくて粘りが強い が、ジャポニカモチよりは粘りが弱かった。米飯物性に影響を与える枝付け酵素や GBSS の欠損を検出可能な PCR 用プライマーが作成され、これらの突然変異を、一粒の試料に よって検出することが可能となった。

\section{Cp-1 小麦澱粉の老化機構}

\section{( ${ }^{1}$ 琉球大 $\cdot$ 生資、 2 鹿大 ·生資) $\bigcirc$ 田幸正邦 ${ }^{1}$ 、宮里苗子 ${ }^{1}$ 、 花城 勲 2 、竹田靖史 2 、檜作 進 2}

[目的] 演者らは先に小麦澱粉の糊化機構を検討した(1)。ここでは、小麦 澱粉を加熱溶解させ、一定温度で保存した後、動的粘弾性を測定して老化 機構を検討した。

[万法] 小麦澱粉はハルバードとロ一ゼラを使用した。両者のアミロース 含量はそれぞれ23.0および23.9\%であった。澱粉は100ㄷで30分間加熱溶解 後、 $25^{\circ}$ および $4^{\circ} \mathrm{Cで} 24$ 時間保存を行い、実験に供した。澱粉溶液の動的 粘弾性はレオゴニオメータ一を使用して測定した。

[結果] 小麦澱粉糊化溶液を $25^{\circ} \mathrm{C} て 224$ 時間保存した後動的粘弾性を測定する

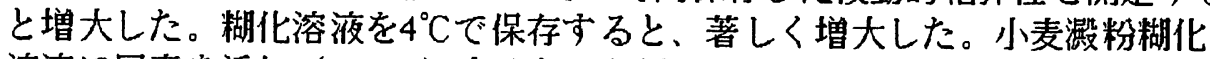
溶液に尿素を添加 $(4.0 \mathrm{M})$ すると、無添加に比較して動的粘弾性が増大し、 $70^{\circ} \mathrm{C}$ で転移温度が認められた。アルカリ溶液 $(0.05 \mathrm{MNaOH})$ に溶解した後、 同様に保存すると、動的粘弾性が增大した。以上の結果から、小麦澱粉の 老化機構を分子レベルで提出した。

1) 田幸、檜作、日本応用糖質科学会大会講演要旨集、2001、p. 416. 


\section{Cp-2 ( (独) 東京文化財研究所・修復技術) (“岡䍜光堂) \\ ○早川典子、川野邊渉、“岡岩太郎}

【目的】古糊は、コムギ澱粉糊を翌に入水水を張り、木蓋と和紙で目張りした後に約10年保存したものであけ 一般のデンプン糊よりも乾燥後の仕上がりが柔らかいため、文化財修復において伝統的に用いられてきている。 製造法としては、保存期間中に毎年糊の上部の水を取り替える方法と、そのまま静置しておく方法とがある。保 管場所は床下が多く、その温湿度環境は通常の人間生活環境に近い、もしくはそれよりもやや緩和された環境で ある。古糊については、激粉に比べて分子量の低下が指摘されており、その要因は凍結融解による浿粉の極端な 老化であるとの報告”もある。本研究では製造環境やロット (湏) の異なる複数の古糊サンプルを、GP C測定 と有機酸分析を用いて分析し、古糊の物質特性を究明することを目的とした。

【方法】古糊を、製造方法、保管年数、保存環境、サンブリング箇所の4条件により分類し、試料とした。G PC 分析には、試料を前処理せず0.1mmoLiCl/DMSOの溶媒に溶かして用いた。有機酸分析には、試料をイオン

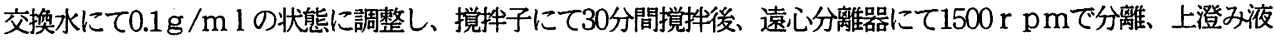
を $0.45 \mu \mathrm{m}$ フィルターで濾過して測定試料とした。

【結果】 GPC測定により得られた結果では、同じ装内の古糊でも、上部数cmから採取した試料は2〜3万程 度の分子量、30cmほどの深さから採取した試料は10万を超える分子量であった。この傾向は製造方法が異なっ

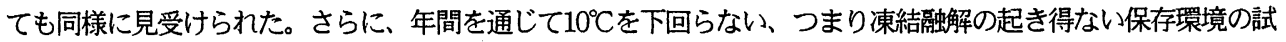
料でも同様の傾向か確認された。また、保管し始めて1年ほどの試料からはブドウ糖と推定される180程度の分 ピークが大きく検出されるが、10年経った試料では検出されず、古糊生成に生物分解の寄与の可能性が示され た。有機酸分析では、乳酸や酶酸と思わ㧈るピ一クが大きく検出さ㧈、加えて水替えをせずに保管したものでは マレイン酸ピークが他と比較して大きく検出されており、微生物関与を示唆している。

1）山田哲也ら : 応用糖質科学43 (2)、pp137-142 (1996)

\section{Cp-3（株マスヤ、*三重大·生資）○西谷 偉、布目知広、*久松 嘪}

目的 高齢化が進むにつれてソフトタイプの粳米菓（煎餅）の需要が期待される。煎餅の食感は 生地の脰化と関係するが、グルテンや添加㓮のない煎餅の膨化は、実際に使用されている特定米 款（くず米）の澱粉の違いに影響されると推察される。本研究では、鼔化性の異なるくず米を用 い、潵粉主成分のアミロペクチン構造特性と膨化性の関係を調べた。

方法 産地別特定米穀 2 種類（北海道産:H、中部産:C）について、製粉-生地-乾燥-焼成の各工 程を経て煎餅を作成した。煎餅の臌化（ウキ）は単位重量に対する容積の割合(比容積)で評価した。 有坂の方法をもとにし、煎餅生地の 0.04\%SDS に対する溶解性(分散度)を測定した。アミロペク チン外層部の鎖長分布は最近開発された久松らの方法に従って分析した。

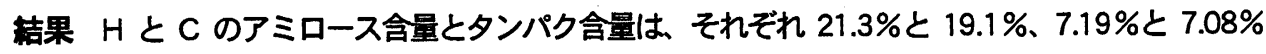

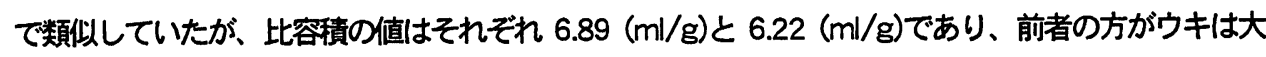
きかった。生地工程から乾燥工程へ粳米菓生地が加工されていく間の澱粉物性変化を、分散度で 調べたところ、H は 29.8\%から 28.0\%とわずかな变化であったのに対し、C は $32.9 \%$ から $20.4 \%$ と大きく変化し、後者の方が老化性か高いと考えられた。H のアミロペクチン外層部の鎖長分布 は、キララと同様 DP12-13 より短い鎖長が C やコシヒカリと比べかなり多く、H の生地は老化 しにくいと推察された。 以上の結果より、乾燥工程で殿粉の絡みか緩やかで柔らか目のH生地は、 焼成工程で生地内の水分が気化するときに膨化しやすく、高いウキ值か淂られると考えられた。 


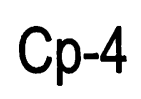

高度分岐澱粉の添加が澱粉製品の物性に及ぼす影響について

('大阪樟蔭女大·食物栄養, ${ }^{2}$ 江崎グリコ’生物化学研, ${ }^{3}$ 秋田総食研)

○川端康之 ${ }^{1}$, 高田洋樹 ${ }^{2}$, 戸枝一喜 ${ }^{3}$, 北尾悟 ${ }^{1}$, 高橋徹 ${ }^{3}$, 柴本憲夫 ${ }^{3}$

【目的】Neurospora crassa 由来のグリコーゲン枝作り酵素を澱粉湖化液に作用させることに より，高度な分岐構造を持ち糊化液がほとんど老化しない水溶性の澱粉 (高度分岐澱粉. HBS) を調製できる1)。HBS の用途開発への知見を得る目的で, 澱粉糊化液などにHBS を添加し，そ の物性変化について検討した。

【方法】溊粉糊化液に HBS を添加したときの粘性挙動の变化はB型粘度計を用いて検討した。 HBS の添加が澱粉の糊化過程に与える影響についてはラピッドビスコアナライザーを用いた。 HBS を添加した上新粉だんごを調製し，冷蔵保存後の硬化度をテンシプレッサーで測定した。 【結果】澱粉糊化液に HBS を添加した場合，固形分の増加にも関わらず粘度低下が認められ た。また, 米粉港粉にHBS を共存させて糊化過程をRVA で追跡したところ, 最高粘度と最終粘 度の低下が認められた。上新粉だんごを調製し冷蔵保存後の老化による硬化の度合いを測っ たところ, HBS を添加すると硬化が抑制される傾向があった。このことから，HBS は澱粉の糊化 過程においてその水和を促進し，老化による離水を抑制する機能をもつことが予想された。

1) Kawabata et al., J. Appl. Glycosci., 49(3), 2002, in press.

\section{米の浸漬温度による米飯食味改変 \\ (静岡大・教育) ○新井映子}

【目的】先 "に演者らは, 常温よりも高温で米を浸漬すると, 米飯のテクスチ ヤーや甘味が向上することを明らかにした. 一方, 米を常温よりも低温で浸漬 すると, テクスチャーが改善されるとの報告もある. そこで本研究では, 米の 浸漬温度を調節することにより, 米飯の食味改変が可能であるか否かを明らか にするため, 7 段階に温度を変えて浸漬した米について, 米飯テクスチャーお よび呈味成分の変動について検討を行った.

【方法】供試米には広島県産のコシヒカリおよびどんとこいを使用した。米の 浸漬温度は, $1,10{ }^{\circ} \mathrm{C}$ (低温), $20^{\circ} \mathrm{C}$ (常温), $30,40{ }^{\circ} \mathrm{C}$ (中高温)および 50,60 ${ }^{\circ} \mathrm{C}$ (高温) に設定した. 洗米後の米を各設定温度で 1 時間浸漬後, 浸漬液ごと 電気炊飯器で炊飯した. 米飯の評価は, テクスチャー ( 3 粒法), 遊離糖 (HPLC), L-グルタミン酸（F-キット）および官能検査によった.

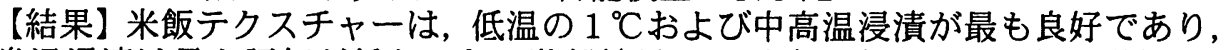
常温浸漬は最も評価が低かった。遊離糖量は, 浸漬温度の上昇と共に増加した が, 糖組成には変化が認められ, 中高温浸漬まではマルトオリゴ糖類が多く生 成したのに対して, 高温浸漬ではグルコースの増加が著しかった. L-グルタミ ン酸量は, 中高温浸漬で最高值となり, 高温浸漬で最低值となった. 以上の結

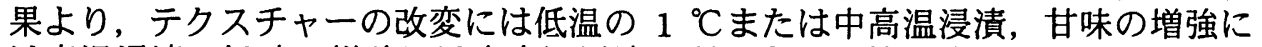
は高温浸漬, 旨味の増強には中高温浸漬を利用すると効果的であることが判明 した。なお, テクスチャーと甘味の変化は, 官能検查においても確認された.

”新井他：家政誌, 48, 789-795（1997）. 


\section{サコ被粉を用いたビスケットの物性，官能評価に及ほす各璉輛類添加の影響 \\ Cp-6 (共立女子大·家政, *生研機搆) \\ ○平尾和子，反町秀子，濱西知子，"貝沼圭二，高橋節子}

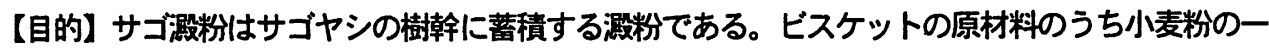

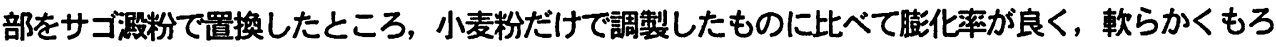

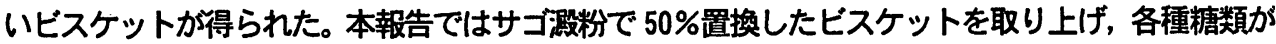
サコ溜粉ビスケットの外観，物性および官能評価に及ほす影響について検討した。

【方法】糖類はグラニュー糖, 上白糖, 粉糖, トレハロースおよびエリスリトールを用いた。トレ ハロースとエリスリトールでグラニュー糖の $25 \%$ あるいは $50 \%$ を置換した。材料の配合は粉 (小麦 粉 : サコ弫粉=1:1） 100 に対して無塩バター45\%, 糖類 30\%，牛乳 20\%の割合とした。ビスケット のドウはフードプロセッサーを用いて調製し，粉と室温に戻した無塩バターを混和したのち糖類， 牛乳の順に入れて混捏した。ドウは厚さ $3 \mathrm{~mm}$ に圧延して 1 時間冷凍後, 直径 $3.8 \mathrm{~cm}$ の丸型で成形し, $180^{\circ} \mathrm{C} 、 8$ 分間焼成して製品にした。ドウおよび焼成品について, 水分（電子水分計 MC-30MB; 侏長 計量器製作所), 膨化率(菜種法), 重量減少率, 直径および厚さを測定した。物性測定はレオロメー ター(RX-1600, アイテクノ侏製) を使用し, 官能诺価は評点法を用いて行い, 特性と啫好を求めた。

【結果】(1上白糖, 粉糖て調製したビスケットは対照のグラニュー糖に上比べて薄く横に広がり，も ろさの少ないビスケットが得られた。(2)トレハロース, エリスリトールで調製したものは厚みがあ り，対照に比べて有意に硬さを增し，特に50\%置換したビスケットのもろさは非常に大きかった。 (3官能評価において粉糖，上白糖で調製したクッキーは形状やきめか好まれ，硬さ，もろさ，舌触 リや口溶けなどの食感や甘さが好まれた。トレハロースおよびエリスリトールを $50 \%$ 置換して調製 したクッキーは食べた時の食感はよいが, 焼き色がうすく, 甘みが少なく好まれなかった。

$$
\mathrm{Cp-7} \begin{gathered}
\text { サコ澱粉ゲルの老化特性に及ぼすトレハロース添加の影響 } \\
\text { (共立女大·家政, *生研機構) } \\
\text { O濱西知子, 西澤恭子, 平尾和子, }{ }^{*} \text { 貝沼圭二, 高橋節子 }
\end{gathered}
$$

【目的】サゴヤシは赤道を中心に南北 $10^{\circ}$ の間の湿地に自生し，その幹に約 $200 \mathrm{~kg}$ の澱粉を蓄積 する。他の作物が生育し難い低湿地に高い適応性を示し環境保全作物としても注目を集めている。 サコ港粉は赭潤・溶解しやすくゲル形成性に優れていることが知られている。本研究においてはサ コ澱粉を用いて日本の伝統菓子わらひ餅を調製した。この際，老化抑制効果が期待されるトレハ口 一スを添加し，その効果について他の天然激粉およびショ糖と比較検討した。

【方法】試料はサコ澱粉（マレーシア連邦サラワク州産 : 島田化学(株))，馬鈴著澱粉（ホクレン 中斜里工場), 甘藷激粉 (島田化学(株)), とうもろこし激粉 (日本食品化工(株)), トレハロース ((株) 林原商事)，ショ糖 (マルハ(株)）を用いた。粘度はラピッドビスコアナライザー(フォス・ ジャパン(株) 製 RVA-3D）により澱粉濃度は $11 \%$ ，糖添加は全量の $30 \%$ として測定した。また澱粉 ゲルの老化特性は粘度測定により得られた糊液を一 $20{ }^{\circ} \mathrm{CC゙} 22$ 時間凍結後，室温で 2 時間解凍した ものを 1 サイクルとし $1 ， 3 ， 5$ および7サイクル後の離水量ならびにテンシプレッサー（タケトモ 電機製 TTP-50-BX) による物性測定を行い，比較検討した。さらに評点法による官能評価を行い「特 性」および「啫好」から食味特性を検討した。

【結果】(1凍結・解凍サイクル時における糖添加ゲルは無添加ゲルに比べて硬さの増加が少なかっ た。特にトレハロース添加ゲルは $5 ， 7$ サイクルにおいて，いずれも硬さは小さい值を示した。(2) サコ港粉ゲルは他の澱粉と比較して 5，7 サイクルにおける硬さおよひ離水量の増加が顕著に抑え られた。(3)官能評価においては，トレハロースを添加したサゴ澱粉ゲルは3サイクル後において, 有意に好まれた。 


\section{Cp-8}

\section{水溶性大豆多糖類の米飯類への応用}

（不二製油株式会社）

前田裕一、O冨尾毅、古田均、浅野裕一、中村彰宏、佐藤陽子、豊福芳子

【目的】食品工業では、米飯類を大量調理・加工する場合に米粒が損傷し、安定した品質の製品 を大量供給する上での大きな課題となっている。水溶性大豆多糖類は高い皮膜形成能を有し、炊飯 時、または調理加工時に添加した場合に、米粒間の過剩な付着を防いで損傷を低減し、また経時に よる硬化を抑制する事が出来る。そこで各種解析手法を用いて、水溶性大豆多糖類が米粒の損傷を 低減し、硬化を抑制する機構の解析を試みた。

【方法】ピリジルアミノ化により蛍光修飾した水溶性大豆多糖類を炊飯時に添加し、巣光顕微鏡 を用いて米粒中での局在部位の特定を行なった。次に水溶性大豆多糖類を炊飯時に添加した米飯の 表面状態を、光学顕微鏡で観察した。続いて食味値、及び物性値の経時変化を、食味計、及びテン シプレッサーを用いて測定した。最後に炒飯に加エした場合のほぐれ性を、レオメーターを用いた レオロジ一解析により測定した。

【結果】 蛍光顕微鏡観察の結果、米粒中での水溶性大豆多糖類は、表層部分に形成される糊粘層、 いわゆる「おねば層」の内側に特異的に局在して皮膜を形成するが、米粒の内部にはあまり浸透し ていない事か確認された。また顕微鏡観察でも表面の平滑性が向上している事が確認された。一方 食味值、物性値共に、水溶性大豆多糖類を添加区の数值変化が少なく、特に低温保存時の経時変化 を抑制している事が示された。またレオロジ一解析の結果、炒飯に加エした米飯のほぐれ性は明ら かに向上していた。これらの結果から、表層部に形成した皮膜層が米粒の表面を強化し保型性を著 しく向上する事で米粒の損傷を防ぎ、また澱粉分子に作用して水分の蒸発を抑制し、結果として良 好な加工適性と硬化抑制機能を付与していると考えられた。

\section{Cp-9＼cjkstart湿熱処理ハイアミロースコーンスターチの胆汁酸吸着性 \\ （長岡高専専攻科·物質工, 日本食品化工・研, ${ }^{2}$ 長岡高専·物質工） ○近藤妙子, 伊藤剛', 菅原正義 ${ }^{2}$}

【目的】ハイアミロースコーンスターチ(HAS)に湿熱処理を行つた湿熱処理HAS(HMT)は、難 消化性澱粉素材(含量約70\%)として有望であり、これまで我々は腸内環境改善や胆汁酸排泄 促進などの各種生理的機能性について報告してきた。HMTは、小腸において消化吸収がされ 難く、胆汁中に分泌された胆汁酸を吸着すると再吸収を抑制することが期待される。今回、in vitro.におけるHASとHMTの各種胆汁酸吸着能を調べる目的で実験を行つた。

【方法】HASとHMTを、コール酸、ケノデオキシコール酸(一次胆汁酸)、デオキシコール酸、リ トコール酸(二次胆汁酸)水溶液に添加し、液中の胆汁酸濃度の変化を醉素法で測定し吸着量 を調べた。また、遊離、タウリン抱合、グリシン抱合型の胆汁酸の吸着への影響、胆汁酸濃度、 $p$ Hの吸着への影響を調べた。

【結果】コール酸濃度を一定にした場合、吸着時間による吸着量への影響は認められず、コ一 儿酸溶液のpHを変えた場合、澱粉 $1 \mathrm{~g}$ 当たりのコ一ル酸の吸着量は、pH 5: $0.48 \mu \mathrm{mol}, \mathrm{pH}$ 6: 0.39, pH 7: 0.33, pH 8: 0.31と酸性条件下で増加した。また、コ一ル酸濃度を変化させると 濃度増加にともない吸着量も増加した。2.5mMコ一ル酸溶液 $(\mathrm{pH} 7$ )では、コ一ル酸の種類に よる差は少なく、タウリン抱合とグリシン抱合型より遊離型が多かつた。また、この条件におけ るコール酸の澱粉 $1 \mathrm{~g}$ 当たり吸着量は、HAS: $4.0 \mu \mathrm{mol}, \mathrm{HMT}: 5.5 \mu \mathrm{mol}(2.3 \mathrm{mg})$ であつた。 


\section{Cp-10 トランスグルタミナーゼ(TG)によるもち性小麦添加翅の物性

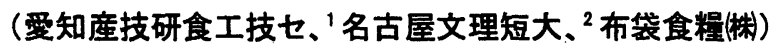 \\ O児岛雅博、1三輪菜美子、源口展之、村瀨 誠、鈴木博久}

【目的】近年開発されたもち性小麦は、その利用面の開発が期待されているが、単独では翅 になりにくく、物性改良的な利用が考えられる。そこで、ASWをベースとする小麦㸮にもち性 小麦粉を添加したときのゆで翅の物性変化について検討するとともに、トランスグルタミナ一ゼ (TG)を添加したときの物性変化についても検討した。

【方法】もち性小麦として、関東糯121号(埼玉産)及び東北211号(茨城産)を、また比較と してWW、ホクシン(内麦)を使用した。ASWを対照として、このうちの 20\%を上記の小麦粉に 置き換え、加水量 $35 \%$ 、食塩量 $2 \%$ の条件で、またTGは加える水に分散させて添加し、翅帯 を調製した。翅帯をラップで包み、所定時間放置後生缅を調製した。これを水分含量 $75 \%$ にな るようゆで、密閉容器中に1時間放置した後、物性測定に供した。

【結果】ゆで麺の引張り強度は、対照である ASW100\%が最も高く、他の小麦粉を添加した場 合、引張り強度は約 20\%低下した。また缅帯での放置時間による影響はほとんど認められな かった。TGを小麦粉に対し $0.4 \%$ 添加した試料では、翅帯での放置 0 時間では、TGの効果は ほとんど見られなかったが、放置時間の増加に伴い、増加率に差はあるもののいずれの試料 も引張り強度は増加した。伸び率についても、TG0.4\%添加翅では、ASW より高い傾向が認め られた。以上の結果から、ASW にもち性小麦粉を添加すると引張り強度は低下したが、TG を 加え、一定の放置時間をとることで、ASW と同等の引張り強度を持ち、伸びのある翅が得られ るものと考えられた。

\section{南米植物 Flamboyan 種子の多糖類の構造 \\ （酪農大院・食品科学） \\ Doris Morochi，小野寺秀一, ○塩見徳夫}

〔目的〕我々は、南米ボリビアに自生している Flamboyan 樹 (Delonix regia) の 種子に存在する多糖類を食品素材として利用するため、粘度特性、 $\mathrm{pH}$-温度安定性 などを調べた。今回はこの多糖類の基本構造の解析を試みた。

〔方法と結果〕Flamboyan 種子の種皮を除き内部をを粉末化した。これをエタノ ルーベンゼン (1:2) で脱脂処理後、70\%熱エタノール抽出を行った。残渣 について熱水抽出を行い、隇圧濃縮後凍結乾嬠し、得られた白色粉末を糖試料と した。このものは酸加水分解により Mannose とGalactose を6:1の比で遊離し、 部分加水分解により得られたオリゴ糖は $\beta$-Mannosidase , $\alpha$-Galactosidase 処理 により Mannose およびGalactose を遊離した。 また、このものの完全メチル化物のメタノール分解物の GLC 分析により $\mathrm{Me}-2$, 3,4,6 - terta-o-Me -Man, Me-2,3,6 -tri - o -Me-Man, Me -2,3 - di - o-Me Man, Me - 2,3,4,6 - tetra-O-Me-Gal の遊離することがわかった。 以上のことから Flamboyan 種子の多糖類は $\beta 1 \rightarrow 4$ 結合したMannan 主鎖に Galactose が $\alpha 1 \rightarrow 6$ 結合した Galactomannan であることが確かめられた。 


\section{リンゴ果実の生育中における Xyloglucan の変化 (弘前大・教育) O伊藤聖子，加藤陽治}

【目的】果実の成熟・軟化の過程における壁多糖の構造変化が示唆されている。それには、 細胞壁多糖とそれを分解する醭素が関与しているとされている。しかし、組織軟化に関して 品種間で大きな違いがみられるなど、軟化機構解明に関しては未だ不明な点が多い。そこで、 われわれは、リンゴ果害の軟化機構解明の基礎知見を得るために、主要へミセルロースであ る Xyloglucan について、その構造を構成オリゴ糖単位で解明し、生育中における変化につい て検討することを目的とした。

【方法】弘前大学農学生命科学部附属藤崎農場において栽培したリンゴ “スターキング・デ リシャス（SKD）”を用い、生育時期の異なる果実可食部から水可溶性と水不溶性細胞壁画分を 得、それぞれXyloglucanを調製した。これを電気泳動的に均一に精製した Geotrichum sp. M128 由来 Xyloglucanase 及び Eupenicillium sp. M451 由来 isoprimeverose-producing oligoxyloglucan hydrolase を用い、オリゴ糖断片に分解した。生成オリゴ糖を HPAEC と MALDI-TOF-MS 法を組み合わせ、構造解析を行った。

【結果】Xyloglucanase 処理により得られたオリゴ糖断片の構造を解析した。リンゴ果実の水 可溶性・水不溶性細胞壁画分のXyloglucan は、いずれも、XXXG、XXLG、XLXG、XXFG、XLLG及 びXLFG などを主要オリコ糖単位として有していた。生育が進むにつれて、両画分でのこれら オリゴ糖の含有比に変化がみられ、Xyloglucan 分子の生育中での変化が示唆された。

\section{Da-3 納豆菌菌体から得られた多糖について (大阪市立大・理学研究科 ${ }^{1} 、$ 木内医院 ${ }^{2}$ ) O飯塚 勝 ${ }^{1}$ 、才内直人 ${ }^{2}$}

（目的）細菌のエキソポリサッカライドについての構造と機能の研究は多く 報告されているが、菌体内の多糖についての報告は少ない。今回納豆菌の lysateに含まれる多糖をクロマトグラフィーにより分離し、多糖の性質と機能 について検討してみた。

（方法）培盖菌体を洗浄し、凍結融解を繰り返し、lysateとして得られた 可溶画分の遠心上清を膜濃縮し、Bio Gel P-2のクロマトで分離し、多糖画分 を得た。その分離精製したものについてTLCおよびHPLCで分析した。また、 機能についてはMolt-4細胞（ヒト白血病樹立細胞株）およびHeLa細胞（ヒト 子宮頚ガン樹立細胞）の増殖抑制効果を検討した。

（結果）多糖画分としてえられたものには 2 種の多糖が含まれていた。これら の混合物は試した両ガン細胞の增殖を抑制する効果を示した。 2 種の多糖の うち 1 種はNMRの分析からDextranと類似していたが、 dextranaseで分解され なかった。検討中の他の多糖の同定とともに得られた結果について報告する。 
$\begin{array}{ll}\text { Dsp. niger APC-9319 } \alpha \text {-ガラクトシ } \\ \text { Da-4 } & \text { オリゴ糖 ( } \alpha \text {-GOS }) \text { の免疫調節機能 }\end{array}$

(信州大·エ, ${ }^{1}$ 信州大·農, ${ }^{2}$ 横浜国際バイオ研, ${ }^{3}$ 天野エンザイム, $\left.{ }^{4}\right)$ 北 大院・農, ${ }^{5}$ 大阪市工研）○山下亜希子, ${ }^{1}$ 橋本博之, ${ }^{2}$ )藤田孝輝, ${ }^{3}$ )岡 田正通, ${ }^{3}$ 森 茂治, 天野良彦, 神田鷹久, ${ }^{4}$ 園山·慶, ${ }^{5)}$ 北姆事美雄

【目的】ラフィノースやメリビオースなどの $\alpha$-ガラクトシル基を含むオリゴ糖は, 強いビフィズス 菌選択增殖活性の他に, 免疫細胞活性化作用, 制がん効果, アトピー性皮膚炎の改善効果 など様々な生理機能を有することが報告されている. 生体内には， $\alpha$-ガラクトシル基は主とし て $\alpha$-ガラクトビオース( $\alpha$-Gal2)の形で存在するため, これらの機能の本体は $\alpha-G a l 2$ と考え られ， $\alpha$-Gal2 は新しい機能性を持つ食品や医薬品素材として期待できる. 演者等は, Asp. niger APC-9319 株由来の $\alpha$-ガラクトシダーゼの縮合反応を用いて, ガラクトースから $\alpha$ -Gal2 を主体とする $\alpha$-結合ガラクトオリゴ糖 ( $\alpha$-GOS)を製造する方法を確立し ${ }^{1)}$ ，その機能 について検討している. 今回は, $\alpha$-GOS の免疫調節機能について報告する.

【方法と結果】 $\alpha$-GOS は, マウスを用いた系で, 経口投与により, アレルギ一疾患の増悪因 子と考えられる腸内カンジダ菌に対してラフィノースよりも強い抑制効果を示した. また， $\alpha$ -GOS の経口投与は, ヒト慢性関節リウマチの病体モデルであるラットのアジュバント関節炎 に対して抑制効果を示した. 投与した抗原に対する抗体の応答がヒトに近い Brown norway ラットを用いて，卵白アルブミン(OVA)をモデル抗原としたアレルギ一性喘息モデルを作成し た. この系で， $\alpha$-GOS の経口投与は, OVA 特異的 IgE レベル及び気道への好酸球浸潤を 抑制した. また, $\alpha$-GOS はOVA による経口免疫寛容の誘導を促進し，食品アレルギーの予 防，低減にも有効であることが示唆された。

1)応用糖質科学, 48, 4, 413(2001)

\section{$\begin{array}{ll}\text { Da-5 } & \text { リン酸化オリゴ桾カルシウム(POs-Ca)のラットにおける生体利用性 } \\ \text { （江崎グリコ・生化研、'大阪市立大·院生活科学、尓都府立大·人間環境） }\end{array}$ \\ ○戸尾健二、釜阪 寛、西村隆久、栗木 隆、1佐伯 茂、²中坊幸弘}

【目的】馬鈴薯澱粉由来 POs-Ca は、グルコ一ス残基の 6 位または 3 位にリン酸基を有する平均重 合度 4 のオリゴ糖であり、カルシウム(Ca; 5wt\%)塩として調製してきたものである。我々は POs $-\mathrm{Ca}$ の $\alpha-1,4$ 結合に対するアミラ一ゼの作用特異性 ${ }^{1)}$ 、および 6 位リン酸基に対する酸性ホスフアターゼ の作用特異性2)について報告してきた。今回、ラットを用いて、POs-Ca の消化性3)と共に可溶性 Ca 素材としての Ca 吸収性についても検討したので報告する。

【方法·結果】ラットに POs-Ca を経口投与して血糖値の変動を調へだ結果、マルトオリゴ糖と同様の 消化性の高さが示唆された。POs-Ca(400mg)をラットへ投与した場合、血糖值は 30 分後に最大に 到達し、その後速やかに低下した。この血糖値の変動は、対照に用いた同量のグルコ一スあるいは マルトテトラオース主体のマルトオリゴ糖混合物を投与した場合と同様であった。更に血中の Ca とリ ン(P)の濃度変動を比較したところ、Pの変動は各群に違いはなかったが、CaはPOs-Ca 群で投与後 15-30 分にかけて有意な上昇が钼察された。次に、空腸結㲈ル一プを用いて POs-Ca と可溶性 $\mathrm{Ca}$ 素材(塩化 $\mathrm{Ca}$ ，乳酸 $\mathrm{Ca}$ )または不溶性 $\mathrm{Ca}$ 素材 (リン酸水素 $\mathrm{Ca}$ ，炭酸 $\mathrm{Ca}$ ) との Ca 吸収性を比較した。 その結果、POs-Ca は可溶性 $\mathrm{Ca}$ 素材と同様の高い Ca 吸収性を示し、不溶性 Ca 素材と比較して有 意に吸収性が高かった。以上の結果から、摂取したPOs-Caは小腸で容易に消化吸収されるために 下痢を引き起しににくだけでなく、吸収性のよい Ca 素材にもなりうるオリゴ糖であることが明らか になつた。

1) Kamasaka, H. et al. 1997. J. Appl. Glycosci., 44: 275-283.

2) To-o, K. et al. 2000. Biosci. Biotechnol. Biochem., 64: 1535-1537.

3) To-o, K. et al. 2002. J. Appl. Glycosci., 49: 159-165. 


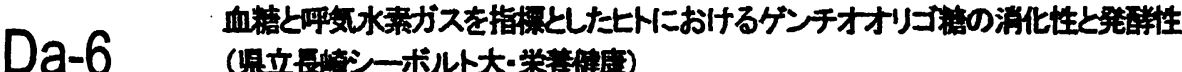

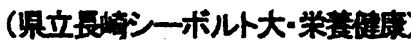

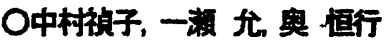

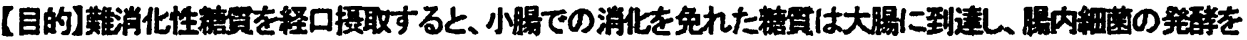

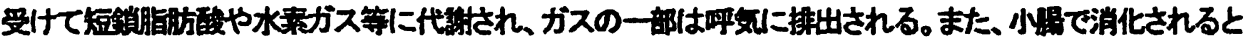

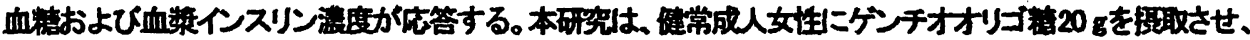

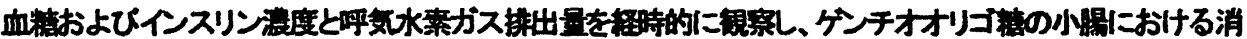

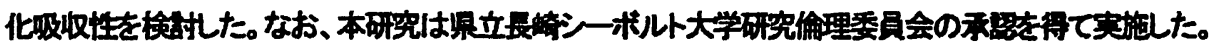

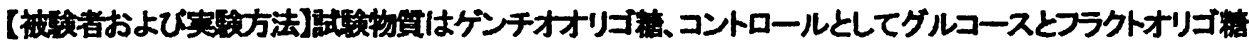

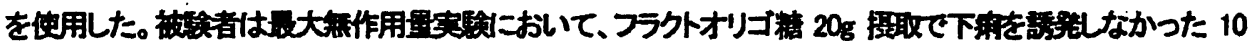

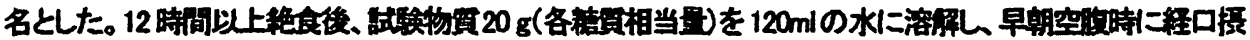

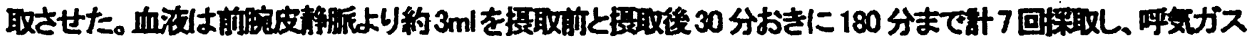

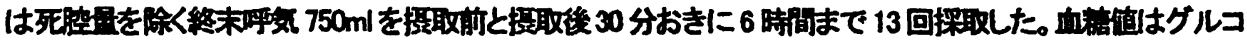

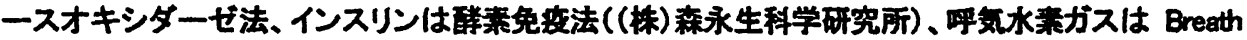
Analyzer TGA2000(テラメックス)によって䑍定した。

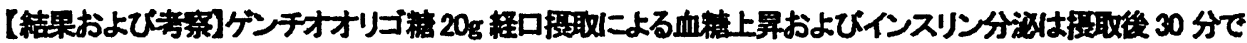

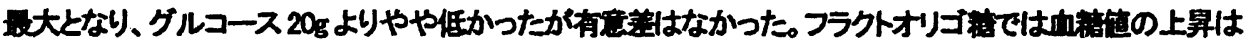

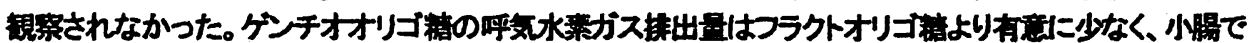

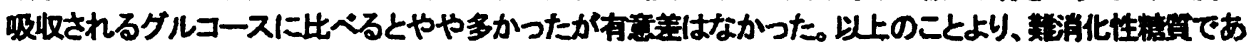

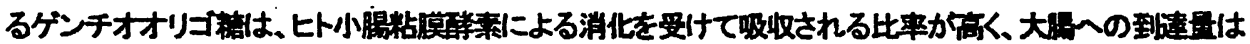

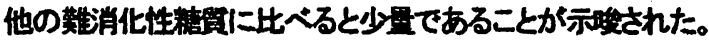

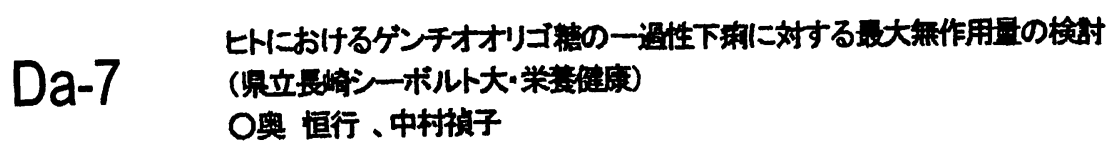

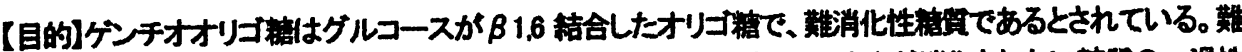

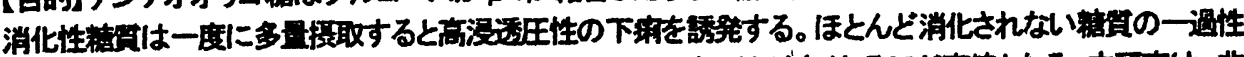

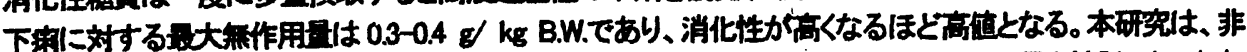

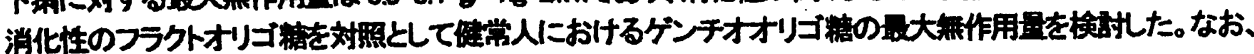

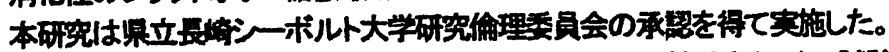

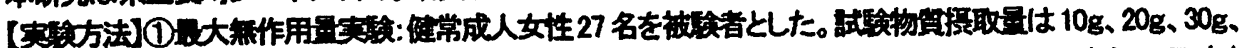

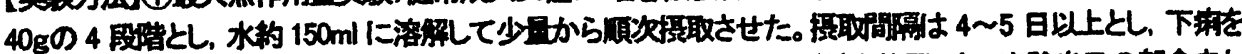

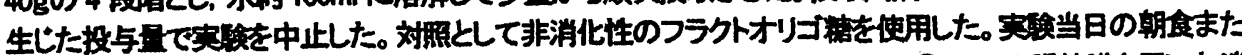

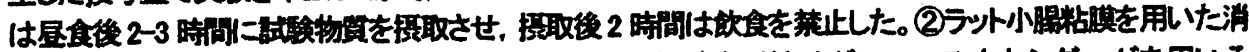

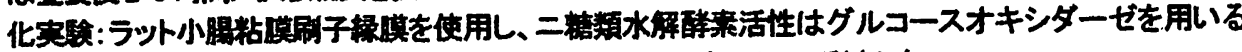

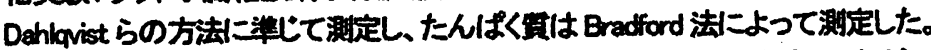

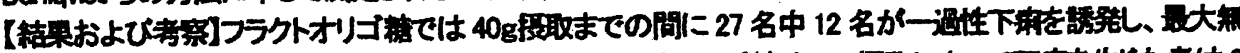

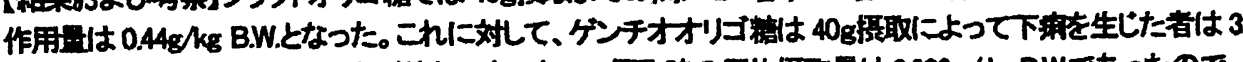

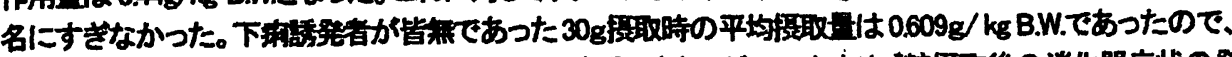

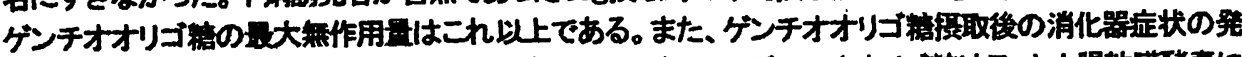

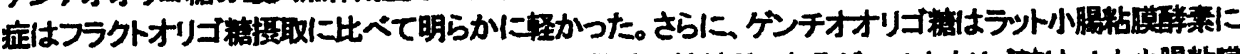

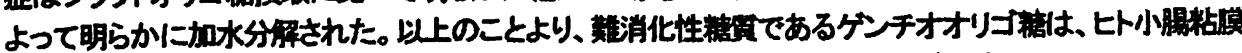

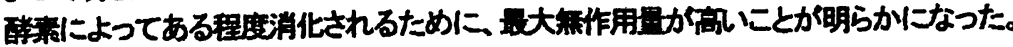




\section{Da-8 (林原生化研) O 奥和之、黒頛直弓、澤谷郁夫、久保田倫夫 \\ 福田恵温、栗本雅司、辻阪好夫}

【目的】トレハロースは、激粉老化防止、蛋白安定化、脂頯变敗抑制などの機能を有して いる。またマグネシウム（M g ）などミネラルと相互作用することも報告されている*。 肉や野莱の調理時に発生するアクはミネラルと関係があり、トレハロースがアク発生を顕 著に抑制することが知られていたが、抑制機作についてはほとんど研究されていない。 今回、肉や野莱など加熱時ミネラル溶出に及ぼすトレハロースの影響とアク抑制について 検封した。

【方法】市販肉（豚肉）、野菜（春菊、ほうれん草など）を糖筫（トレハロース、ネオト レハロース、スクロース、マルトース）水溶液に漫し、加熱して沸腾させた後、室温まで 自然放冷した。肉、野菜を除去した後、铜理液を桐山濾紙で滤過して、残渣（アク）と滤 過液を分離した。ミネラルは原子吸光度法で、蛋白䓄はローリー法で、脂筫はクロロホル ム・メタノール抽出して測定した。

【結果】試験した糖筫のうち、トレハロースのみが顕著にアク生成を抑制し、糖筫無添加 の 54\%（トレハロース濃度 2\%）～71\%（トレハロース濃度 10\%）の抑制率であった。 アク組成を調ベたところ、蛋白質や脂筫含量には变化がなかったが、 $\mathrm{Mg}$ 含量が顕著に減 少していた。滤過液中のミネラル分析の結果、トレハロース存在下でM g 含量のみ低下し ていた。 $\mathrm{Mg}$ 溶出量を算出したところ、トレハロースは肉から約 $40 \%$ 、野菜から約 $48 \%$ の溶出抑制率であった。以上のことから、トレハロースは肉や野菜からの $\mathrm{g}$ 溶出を抑制 することにより、アク生成を抑制していると示唆された。

*奥ら、応用糖躓科学会平成 13 年度大会講演要旨集、p48

\section{Da-9}

環状四糖と低級アルコールとの相互作用

（林原生化研）

O橋本貴治、奥 和之、久保田倫夫、福田恵温、栗本雅司、辻阪好夫

【目的】我々は、新規の 2 種酵素、6 - glucosyltransferase と isomaltosyltransferase を用いて、 洪粉からの環状四糖 cyclo $\rightarrow 3 \mathrm{Glc} \alpha 1 \rightarrow 6 \mathrm{Glc} \alpha 1 \rightarrow 3 \mathrm{Glc} \alpha 1 \rightarrow 6 \mathrm{Glc} \alpha 1 \rightarrow\}$ の新規製造法を報告してい る1)。環状四糖は、サイクロデキストリン (CD) とは異なる環構造で浅い旗みの構造であることが わかっている。今回、環状四糖の低級アルコ一ルとの相互作用を各種 CD 類と比較検討した。

【方法】環状四糖、 $\alpha \cdot \mathrm{CD} 、 \beta-\mathrm{CD} 、 \gamma \cdot \mathrm{CD}$ は林原生化研で調製したものを用いた。分岐 $\mathrm{CD}$ は市 販のイソエリート P (横浜国際ハイオ) を用いた。環状糖質の水溶液に、糖質の3倍モル量の低級 アルコール (メタノール〜ペンタノール) を加え、2 分間ホモジナイズした後、凍結真空乾燥して アルコール含有粉末を調製した。粉末試料中のアルコール保持量はGC 法で定量した。

【結果】環状四糖のアルコール保持能を調へたとこころ、プロパノールの保持が最も高く、環状四糖 当たり 0.53 (モル比) であった。次いでエタノール (0.40)、ブタノール (0.24) の順で、メタノ 一ルとペンタノールの保持は僅かであった。プロパノール、エタノール保持を CD 類と比較したと ころ、プロパノールの場合、環状四糖の保持能は $\alpha \cdot \mathrm{CD}$ に比べ低值であったが、他の CD 類より高 值で、エタノールの場合、環状四糖は $\alpha \cdot \mathrm{CD}$ と同等の保持能を示した。プロパノール含有試料を $25^{\circ} \mathrm{C}$ 、 7 日間放置し、残存量を測定したところ、環状四糖試料の残存率は $\alpha \cdot \mathrm{CD}$ 試料より高いことがわか った。プロパノール含有環状四糖粉末を DSC 分析したところ、環状四糖とプロパノールの両吸熱 ピークに顥著なシフトが観測された。エタノール、ブタノールでも同様のシフトが認められ、環状 四糖と低級アルコールとの相互作用が示㖫され、その相互作用か環状四糖のアルコール保持能の一 因であると考えられた。

1）阿賀ら、日本農芸化学会平成 14 年度大会要旨集 p. 131 


\section{$D p-1$}

カードランの酵素分解によるラミナリオリゴ糖の調製

('食総研、 ${ }^{2}$ 東京理大・生物工)

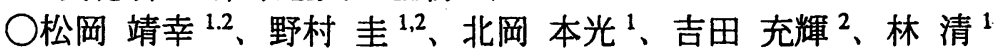

【目的】試薬として高価であるラミナリオリゴ糖を数十グラム調製する目的で、 工業的に生産されている $\beta-1.3$ グルカンであるカードランを醭素分解する方法の 検討を行った。

【方法】 $\beta-1.3$ グルカン分解酵素として、酵母細胞壁溶解酵素製剤 YL-15（天野工 ンザイム）を用いた。酵素反応は、基質濃度 $5 \% 、 40^{\circ} \mathrm{C} 、 \mathrm{pH} 5.5$ の条件で行った。 生成したグルコースを除去することを目的として、酵素反応終了後のパン醳母処 理を検討した。反応液の糖組成はイオンクロマトグラフィーにより測定した。

【結果】反応条件により、ラミナリビオースあるいはラミナリトリオースが主生 成物となるラミナリオリゴ糖混合物を得ることができた。ラミナリビオースは、 酵素濃度 $1.0 \% 、 24$ 時間反応させる条件で生成量が最大になり（収率 $32 \%) 、 ラ ミ$ ナリトリオースは、酵素濃度 $0.4 \% 、 24$ 時間反応させる条件で最大になった（収率 22\%)。反応液をパン酵母で処理すると、グルコースの減少とともにラミナリビオ 一スの増加、ラミナリトリオースの減少が起こり、新規な三糖の生成が見られた。 この現象は、酵母菌体に存在する $\beta$-グルコシダーゼにより引き起こされているこ とを確認した。

\section{Dp-2 擬似移動層式バイオリアクターを用いた乳果オリゴ糖(ラクトスクロー ス)の製造 \\ （横浜国際バイオ研, 1)京大院工）○村上和史, 藤田孝輝, 原耕三, "A.Pilgrim, 1)河瀬元明}

【目的】乳果オリゴ糖(ラクトスクロース:LS)は,ビフィズス菌增殖活性を有する機能性甘味 料として広く用いられている。この LS は, Arthrobactersp. K-1 株由来の $\beta$-Fructofuranosidase ( $\beta$-FFase)の糖転移反応を用いて, 乳糖とシヨ糖から製造されるが, その反応は副 生成物であるグルコースによって阻害されるため, LS 収率は $48 \%$ と低い。そのため実生産 ではインベルターゼ欠䪱醉母を反応系に加え, グルコースを資化させることによって, LS 収 率を $78 \%$ まで高めるている。しかしながら醉母の使用は, 醉母の代謝産物, 菌体成分の溶 出により，精製工程を複雑にしし，歩留まりを低下させ，コストアップの要因となっている。そこ で擬似移動層式クロマト装置に醉素反応を組込み，反応之同時にクロマト分離を行い，平衡 を LS 生成側に移動させることによって，効率的な LS 生産システムを開発するものである。 今回は, 擬似移動層式クロマト装置に $\beta$-FFase 組込むため, LS 生成反応機構を解析し, 擬似移動層式バイオリアクターのシミュレーションを作成し，運転条件を検討した。 【方法と結果】種々の基質濃度にて LS 生成反応を反応速度論的に解析した結果， LS 生成 反応は，2基質 2 生成物反応である Orderd bi bi 機構であったが，付随するショ糖および LS の加水分解も考膚した複雑なものとなった。この反応機構を擬似移動層式クロマト装置に組 込んだパイオリアクターのシミュレーションを作成した。得られたシミュレーションの最適値を 基に、擬似移動層式クロマト装置（\$36 mm × $1500 \mathrm{~mm} \times 10$ 本，オルガノ獭製)に遊離 $\beta$ -

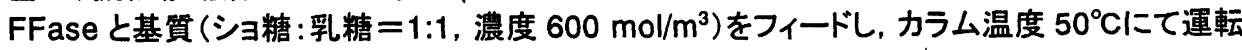
し，回分反応を超える収率 $56 \%$ (純度 70\%)で LS 製造することが出来た。 


\section{Dn-3 Simultaneous synthesis of panose in lactate-fermented foods using acceptor reaction of glucansucrase (Department of Food Science and Technology, Research Center for Bioresource and Health, Chungbuk National University) Hyun-Ju Eom, Dong-Mi Seo, Hyang-Sik Yoon, ONam Soo Han}

Production of panose was carried out by using acceptor reaction of glucansucrase elaborated by Leuconostoc mesenteroides during fermentation of kimchi and sauerkraut. As glucosyl donor and acceptor molecules, $2 \%$ of sucrose and $2 \%$ of maltose were added in kimchi and after 5 days incubation at $10^{\circ} \mathrm{C}$ over $60 \%$ of total sugars were converted into oligosaccharides composing of panose, isomaltosyl maltose, isomaltotriosyl maltose, and isomaltotetraosyl maltose. In addition, use of maltose as acceptor molecule in kimchi enabled lowering viscosity by preventing synthesis of dextran-like polymers. The concentration of oligosaccharides was maintained for three weeks as same level when preserved at $4{ }^{\circ} \mathrm{C}$. Due to the fructose molecules released from glucansucrase reaction, sweet taste of kimchi was not much altered. Leuc. mesenteroides producing a highly active glucansucrase at low temperature was isolated from kimchi and sauerkraut and used as a starter culture for the preparation of those foods. The starter addition shortened the time for the acceptor reaction.

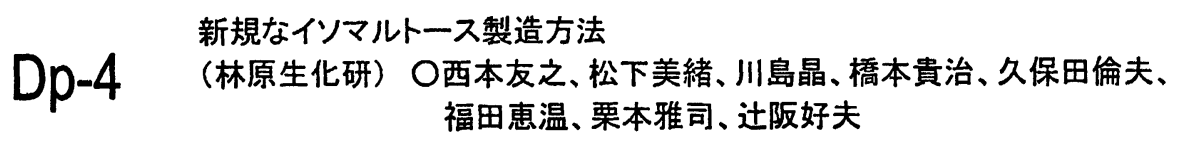

【目的】先に我々は、澱粉から環状四糖を生成する新規な2種酵素について報告した*。その

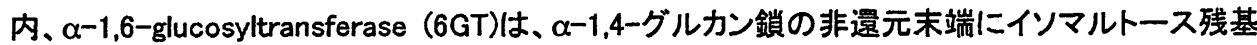
を生成する酵素であった。今回、6GT の作用に注目し、生成したイソマルトース残基を isomalto-dextranase (IDase)で遊離させるという、6GT とIDase とを組合わせた澱粉からの新規 なイソマルトース製造方法を検討した。

【方法】 B. globisporus C11 の部分精製 6GT と、演者ら土壤から新たに分離した Arthrobacter sp. S20-18 の IDase を用いた。両酵素を澱粉部分分解物 (Pinedex)に同時に作用させ、基質の 加水分解率や濃度、酵素作用量、 $\mathrm{pH}$ 、温度など反応条件を検討した。Isoamylase 及び CGTase の添加効果についても検討した。反応物を glucoamylase 処理し、糖組成をHPLC およびGLCで 分析した。

【結果】澱粉部分分解物の加水分解率が低く、基質濃度が低いほどイソマルトース生成率は高 くなる傾向にあり、濃度 2.5 5\%の Pinedex\#100（DE2-5) から 70\%以上のイソマルトース生成 率が得られた。比較的高濃度の 20\%Pinedex\#100を原料として用い検討したところ、6GT と IDase の最適作用量は、それぞれ $0.3 \mathrm{U} / \mathrm{g}-\mathrm{DS}$ と $30 \mathrm{U} / \mathrm{g}$-DS であった。最適温度は $46^{\circ} \mathrm{C} 、$ 最適 pH は 4.9 であった。Isoamylase 及び CGTase の添加は有効で、最適な作用量は、それぞれ 250 $\mathrm{fu} / \mathrm{g}-D S$ と $0.25 \mathrm{U} / \mathrm{g}$-DS であった。この作用条件下で 72 時間反応後、glucoamylase (2 U/g-DS) を添加して 24 時間処理したところ、反応糖組成中、イシマルトースは約 $68 \%$ に達した。

* 西本ら、日本農芸化学会2002年度大会講演要旨集、p130 


\section{Dp-5 1ーケストース結晶の製造と諸性質について \\ (ホクレン, *酪農大院: 食品科学)}

○福森保則，衰岛和良，“山森昭，“小野寺秀一, ”塩見德夫， 竹田博幸

【目的】現在、様々なオリゴ糖の研究・開発がなされているが、結晶性オリゴ 糖については種類が限られている。そこで、本研究ではフラクトオリゴ糖の中で。 三糖類である1ーケストースについて、ショ糖を原料にフラクトシル転移酵素を用 いて製造した。得られた結晶オリゴ糖の物性、加工性、機能性について検討を行っ た。

【方法】E. repens 由来のフラクトシル転移酵素を用いてショ糖と反応させ、 クロマト分離等により精製を行い、1ーケストースの結晶を得た。結晶オリゴ糖の物 性及ひ加工性に関する指標として、吸湿性の他に溶解度、粘度、水分活性、熱安定 性についてショ糖及び既存のオリゴ糖と比較した。また、腸内細菌の資化性、ラッ ト血清中グルコース及びインスリンレスポンスについて調査した。

【結果】得られた結晶は、1ーケストース $98.0 \%$ 以上の組成からなるオリゴ糖で あった。この結晶オリゴ糖は甘味度 30 、粘度はショ糖より高い。熱安定性、水分 活性、溶解度はショ糖と同程度でショ糖と同様の食品への利用が可能と考えられた。 吸湿性も他のオリゴ糖に比べ低い結果であった。

また、in vitroの試験により、1ーケストースはビフィズス菌に資化され、大腸 菌等に資化されないことを確認した。ラットを用いた経口投与試験により、血清中 の血糖値、インスリンに影響を与えないことを確認した。

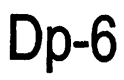

Kojibiosephosphorylaseによる2- $\alpha$-D-glucopyranosylnystose および2(2- $\alpha$-D-glucopyranosyl) ${ }_{2}$ nystoseの合成

（酪農大院・食品科学、林原生化研 ${ }^{*}$ )

○岡田秀紀、小野寺秀一、西本友之*，塩見德夫

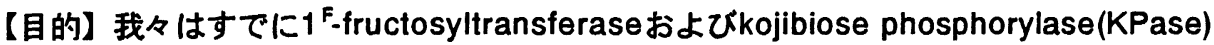
を用い、新しいオリゴ榶、 $1^{F}(1-\beta \text {-D-fructofuranosyl })_{n}$ lactosucrose $(n=1,2)^{1,2)}$ および2 (2- $\alpha$-D-glucopyranosyl $)_{n}$ isokestose $(n=1,2)^{3)}$ を合成した。今回は、KPaseの合成反応 を利用し、供与体を $\beta$-D-G1P、受容体をnystoseとして新しいオリゴ榶の創製を試みた。

【方法】Thermoanaerobacter brockii 由来遺伝子を大腸菌で発現させた組換えKPaseを 用いた。 $0.5 \% \beta-D-G 1 P 、 2.0 \%$ nystose、 $50 \mathrm{mM}$ 酢酸緩衝液 $(24 \mathrm{ml})$ を $50^{\circ} \mathrm{C} て ゙ 2$ 時間 温浴後、 $100^{\circ} \mathrm{C} て 5$ 分間加熱し反応を止めた。醇素反応液について活性炭クロマトグラ フィーおよび調製用HPLC(ODSカラム、 $20 \mathrm{~mm} \times 25 \mathrm{~cm}$ )を用い糖Aおよび䌅Bを単離した。 【結果】糖Aおよひ糖 B は非還元性で、TOF-MS分析により、それぞれ851、1013の [M+Na] +イオンピークを与えた。榶Aおよび榶Bの完全メチル誘运体メタノリゼートの GLC分析、 ${ }^{13} \mathrm{C}-N M R$ 分析により糖Aは2- $\alpha$-D-glucopyranosyinystose、糖Bは2(2- $\alpha$-Dglucopyranosyl) ${ }_{2}$ nystoseであり新しい糖であることが確かめられた。

1) Magn. Reson. Chem., 40 (2002) in press

2) Biosci. Biotechnol. Biochem., 66, 1419-1422 (2002)

3) 日本農芸化学会、大会要旨集 p.238 (2002) 


\section{Dp-7 \\ ナタ豆 $\alpha$-mannosidaseを用いたデオキシオリコ糖類の酻素合成 \\ (日大生資科・農化) \\ ○星野重樹、近藤亮宏、小川真弘、中島康介、松石 紫、河内 隆、 \\ 西尾俊幸、奥 忠武}

【目的】エキソ型糖加水分解醁素であるglycosidaseは、糖加水分解活性だけでなく糖転移 反応によるオリコ糖合成活性も有している。当研究室では数種の $\alpha$-glycosidaseか、基質グ リコシドのモノデオキシ誘導体に対して高い加水分解活性を示すことを見いだした ${ }^{1,2}$ 。前 回、それらの醅素のうちAspergillus niger 由来 $\alpha$-glucosidaseの2-及び3-デオキシ基質反 応性に着目し、本酥素によるデオキシオリコ糖類の合成を検討し報告した。今回は6-デオ キシ-D-マンノシド(D-ラムノシド)分解活性を持つナタ豆由来の $\alpha$-mannosidase ${ }^{3}$ を用い、Dラムノースよりなる二糖誘導体の䤃素合成を行うことを目的とした。

【方法】酥素反応は、糖供与体基質にp-Nitrophenyl $\alpha$-D-rhamnopyranoside、糖受容体 基質としてEthyl $\alpha$-D-thiorhamnopyranosideを用い、酻素にはナタ豆由来の $\alpha$ mannosidaseを用いて、MeCN：0.1M クエン酸Na緩街液=1:1の反応液中で行った。生 成したオリゴ糖はHPLCにより定畐し、それらの構造はNMRなどにより確認した。

【結果】上記条件下での酻素反応の結果、ラムノースよりなる二糖類を2種類得ること ができた。またHPLCによる分析の結果、生成した2種類のD-ラムノース二糖類は、各々 加水分解の受け易さに違いがあることがわかった。

1) T. Nishio, W. Hakamata, et al. : Carbohydr. Res., 337, 629-634 (2002).

2) W. Hakamata, T. Nishio, et al. : Carbohydr. Res., 324, 107-115 (2000).

3) T. Nishio, Y. Miyake, et al. : Biosci. Biotech. Biochem., 60, 2038-2042, (1996).

Dp-8 微生物起源 $\beta$-プリメベロシダーゼによる植物香気前駆体の実践的合成

(静大・農・応生化, *天野エンザイム(株))

○猿渡順考, 戸谷一英, 沼野歌菜子, 村田健臣, 碓氷泰市,

鶴喰寿孝*，佐藤公彦*，森茂治*

【目的】茶, 花の香気成分は， $\beta$-プリメベロシド等の配糖体（香気前駆体）とし て存在し，内在性 $\beta$-プリメベロシダーゼで加水分解され香気を発する. 我々は, カビの一種である Penicillium multicolorから $p$-ニトロフェニル $\beta$-プリメベロ シド $(\mathrm{Xyl} \beta 1-6 \mathrm{Glc} \beta-p \mathrm{NP})$ をエンド的に加水分解する $\beta$-プリメベロシダーゼ様 醉素を見出した. 今回, 本酵素を精製し，糖転移反応の特異性について検討する とともに，植物香気前駆体の䤃素合成を試みた。

【方法】供与体基質として Xyl $\beta 1-6 \mathrm{Glc} \beta-p \mathrm{NP}$ ，受容体基質として 1-アルカノ 一ル及びアルカンジオール $\left(\mathrm{C}_{2}-\mathrm{C}_{12}\right)$ ，アルコール性香気成分（ベンジル及びフ エネチルアルコール，3-ヘキセノール，ゲラニオールなど）を用い，本醳素によ る糖転移反応を行った.

【結果】本醉素による糖転移効率は長鎖の1-アルカノールに対して低いが，水 溶性アルカンジオールに対しては $\mathrm{C}_{12}$ まで二糖転移生成物を確認した。一方, 植

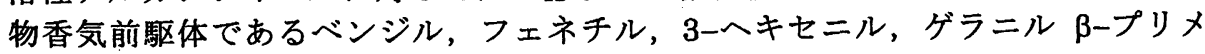
ベロシドは，供与体基質あたり 10〜70\%の収率で生成した。 